Portland State University

PDXScholar

\title{
A study of the diagenesis of the overburden between the Badger and School Coal Seams, Dave Johnston Coal Field, Converse County, Wyoming
}

Rebecca K. Jaffer

Portland State University

Follow this and additional works at: https://pdxscholar.library.pdx.edu/open_access_etds

Part of the Geology Commons, and the Stratigraphy Commons Let us know how access to this document benefits you.

\section{Recommended Citation}

Jaffer, Rebecca K., "A study of the diagenesis of the overburden between the Badger and School Coal Seams, Dave Johnston Coal Field, Converse County, Wyoming" (1983). Dissertations and Theses. Paper 3445.

https://doi.org/10.15760/etd.5329

This Thesis is brought to you for free and open access. It has been accepted for inclusion in Dissertations and Theses by an authorized administrator of PDXScholar. Please contact us if we can make this document more accessible: pdxscholar@pdx.edu. 
AIV ABSTRACT OF TIIE THESIS OF Rebecca $K$. Jaffer for the Master of Science in Geology presented March 9, 1983.

Title: A Study of the Diagenesis of the Overburden Between the Badger and School Coal Seams, Dave Johnston Coal Field, Converse county, Wyoming.

APPROVED BY MEMBERS OF THE THESIS COMMITTEE:

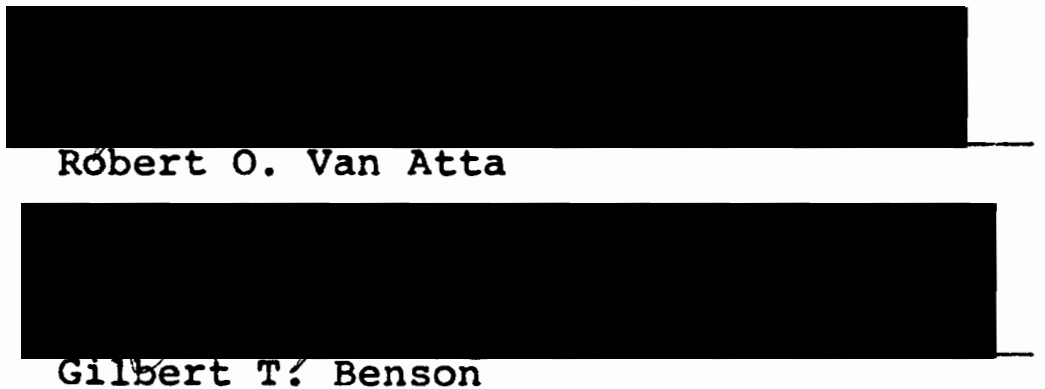

Gibert r? Benson

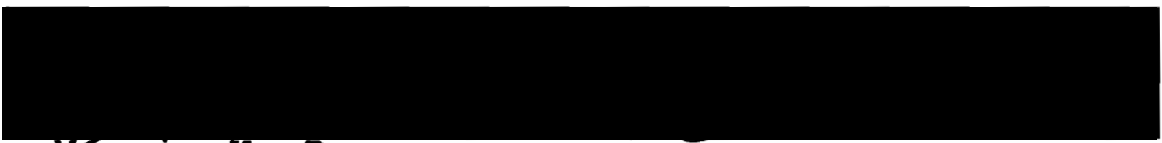

Yarvin H. Beeson

Low $\mathrm{pH}$ zones in portions of the overburden at the Dave Johnston Coal Field, Converse County, Wyoming are the subject of this study. The low pH zones are restricted to limonite stained sandstones which grade downdip into normal $\mathrm{pH}$ gray sandstones. Changes in color, clay mineralogy, cementation and feldspar surface textures are noted between the two sandstone units. These changes appear to be the result of post depositional alteration that was responsible for oxidation of pyrite and chlorite, dissolu- 
tion of calcite, and the etching of feldspar grains. The parameters for the diagenesis fit those of uranium roll front models proposed for the Powder River Basin. The alteration appears responsible for the low $\mathrm{pH}$ values reported in the yellow sandstone. Research by the North Dakota Geological Survey on similar problems associated with lignite mines in North Dakota suggests reclamation procedures for dealing with these potentially hazardous overburden spoils. 
A STUDY OF THE DIAGENESIS OF THE OVERBURDEN BETWEEI TIE BADGER AND SCHOOL COAL SEAMS, DAVE JOHINSTON COAL FIELD, CONVERSE COUNTY, WYOMING by REBECCA K. JAFFER

A thesis submitted in partial fulfillment of the requirements for the degree of

\author{
MASTER OF SCIENCE \\ in \\ GEOLOGY
}


TO THE OFFICE OF GRADUATE STUDIES AND RESEARCH:

The members of the Committee approve the thesis of Rebecca K. Jaffer presented March 9, 1983.

Róbert 0. Van Atta, Chairman

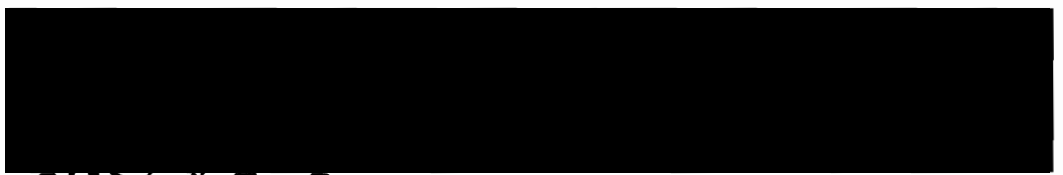

Gilbert 1. Benson

Mgrvin H. Beeson

APPROVED :

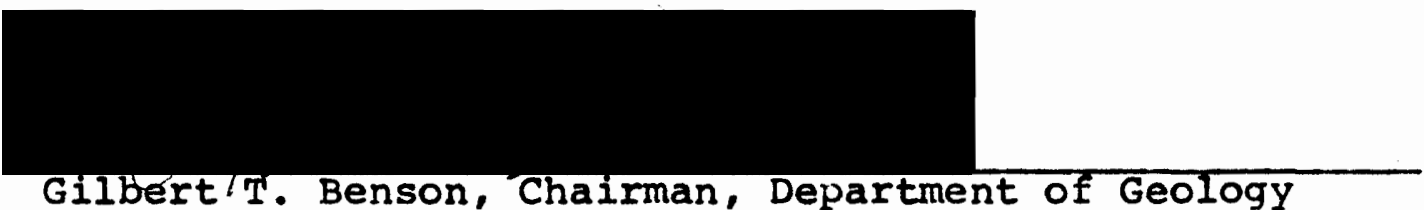

Gilbert/T. Benson, Chairman, Department of Geology

Stanley E. Rauch, Dean of Graduate Studies and Research 


\section{ACKNOWLEDGMENTS}

I would like to thank Dr. Michael Woods and David Schmale for their help, interest, and suggestions during my summer with NERCO and throughout the completion of this thesis.

Many people offered suggestions and encouragement throughout the course of this work, both at NERCO and PSU, and I offer my sincere thanks to those people.

There were five people without whom this thesis would not have been completed. Their support, both financial and moral, ideas, suggestions, criticisms, and assistance made the last two years possible. It is with much gratitude I dedicate this study to Stevie D. (Steven Davis), Mom (Nina Haas), Velocity (Susan Hartford), derF (Fred Gullixson) and that funny looking blond kid (Richard Marty). 
TABLE OF CONTENTS

PAGE

ACKNOWLEDGMENTS

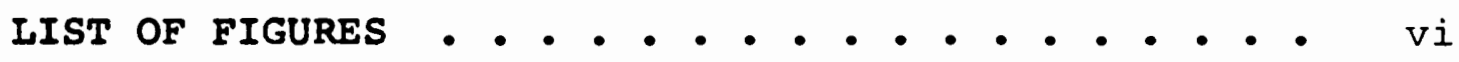
IIST OF PLATES . . . . . . . . . . . . . . viii

CHAPTER 1 . . . . . . . . . . . . . . . . 1

INTRODUCTION . . . . . . . . . . . . 1

LOCATION AND STRATIGRAPHIC BACKGROUND • • • 1

OVERVIEW OF SURFACE MINING • • • • • • • • 5

PROBLEM AND PROCEDURE • • • . • . . . . 6

Chapter 2 . . . . . . . . . . . . . . 12

STRATIGRAPHIC CORRELATION . . . . . . . 12

PETROGRAPHY . . . . . . . . . . . 19

ChAPTER 3 . . . . . . . . . . . . . 24

CLAY MINERALOGY . . . . . . . . . . 24

Chapter 4 . . . . . . . . . . . . . 35

ION DISTRIBUTION • • . . . . . . . 35

Chapter 5 . . . . . . . . . . . . . 39

SCANNING ELECTRON MICROSCOPY . . . . . . 39

ChAPTER 6 . . . . . . . . . . . . . . 44

DISCUSSION AND CONCLUSIONS . . . . . . . 44

Uranium Roll Front Deposits . . . . 44

CONCLUSIONS . . . . . . . . . . 50 
PAGE

CHAPTER

POTENTIAI PROBLEMS FOR RECLAMATION • • • • • 56

REFERENCES • • • • • • • • • • • • • • • 61

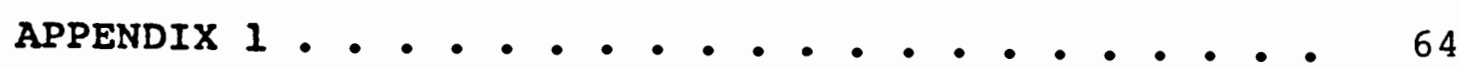

METHODS OF SAMPLE TREATMEINT • • • • • • $\quad 64$

APPENDIX 2 • • • • • • • • • • • • • • • • • 70

X-RAY DATA • . . . . . . . . . . . . 70

APPENDIX 3 • • • • • • • • • • • • • • • • 74

CHEMICAL ANALYSES • • • • • • • • • • 74 


\section{IIST OF FIGURES}

F IGURE

PAGE

1. Map of Wyoming - . . - . . . . . . . . . 2

2. Map of Powder River Basin . . . . . . . . . 4

3. Cross section between drill holes 80001 and 81002 . . . . . . . . . . . . 8

4. Cross section between arill holes 81005 , 80002 and 81004 . . . . . . . . . 9

5. Eocene paleodrainage pattern for Powder River Basin . . . . . . . . . . . . 13

6. Paleocene paleodrainage pattern for Powder River Basin . . . . . . . . . . . . 14

7. Iithogenic model for a fluvial-channeldominated facies . . . . . . . . . . 15

8. Fluvial channel environment . . . . . . . . 17

9. Low-gradient meandering stream environment . . 18

10. Plot of grain mount data . . . . . . . . 23

11. Degradation scheme for montmorillonite clay . . . . . . . . . . . . . . 29

12. Diffraction pattern for sample 81001-OB 8 . . 31

13. Diffraction pattern for sample 81006-OB 14 . 32

14. Untreated and calcium treated diffraction pattern for sample 81006-OB 5. . . . . . 33 
15. Untreated and calcium treated diffraction pattern for sample $80004-O B 10$..... 34

16. Ion distribution data for drill holes 80001 and 81002 . . . . . . . . 36

17. Ion distribution data for drill holes 81005,80002 and 81004 . . . . . . . 37

18. Photomicrograph for smectite clay . . . . 40

19. Photomicrographs for normal pH feldspar ... 41

20. Photomicrographs for low pH feldspar . . . 42

21. Idealized cross section of roll-type ore body . . . . . . . . . . . . 46

22. Summary of mineral deposition in roll-type ore body . . . . . . . . . . . . . . 


\section{IIST OF PLATES}

PIATE

PAGE

I. Location Map of Drill Hole sites . . . . in pocket

II. North-South Cross Section Top of School

Coal Seam Datum . . . . . . . . in pocket

III. North-South Cross Section Ion

Distribution . . . . . . . . . . in pocket 


\section{CHAPTER 1}

\section{INTRODUCTION}

\section{PURPOSE}

The purpose of this study was to identify the causes of low $\mathrm{pH}$ values in the overburden at the Dave Johnston Coal Field. To this end, the study concentrated on identifying possible sources for the apparent alteration of some of the overburden sandstones in which the low $\mathrm{pH}$ values appear to be centered. The study sought to identify parameters defined by the alteration in the sandstones and the possible affects the alteration system could have had on the mineralogy, $\mathrm{Eh}, \mathrm{pH}$ and ion distribution in the sandstones. A detailed diagenetic study was not possible due to the inability to obtain whole rock samples which would have facilitated the study of relationships between porosity, authigenic clays and alteration.

\section{LOCATION AND STRATIGRAPHIC BACKGROUND}

The Dave Johnston Coal Field is located in east central Wyoming, near the southwestern edge of the Powder River Basin (see Figure 1). The Powder River Basin is a broad, asymmetric syncline, which occupies the northeastern corner of Wyoming and adjacent parts of Montana and South 

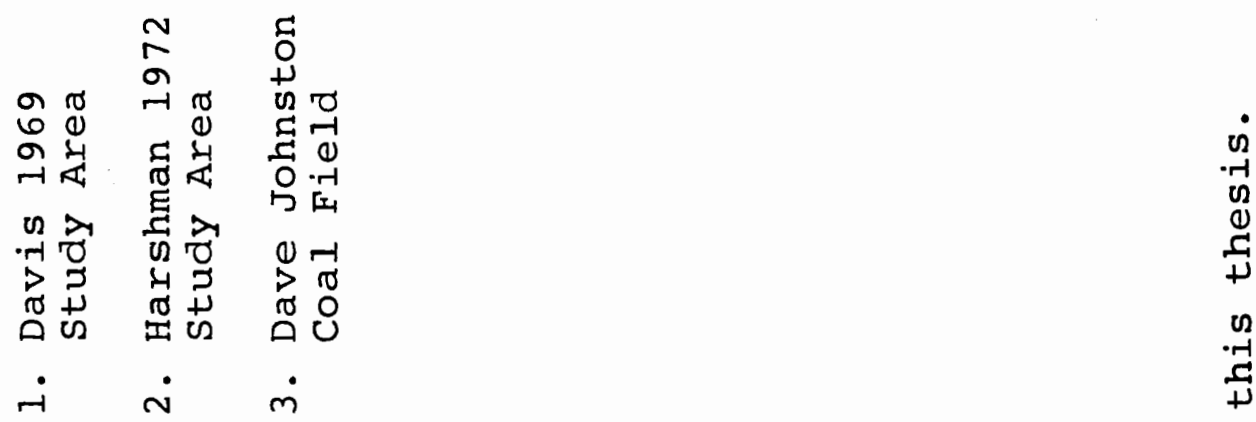

נת

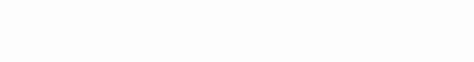

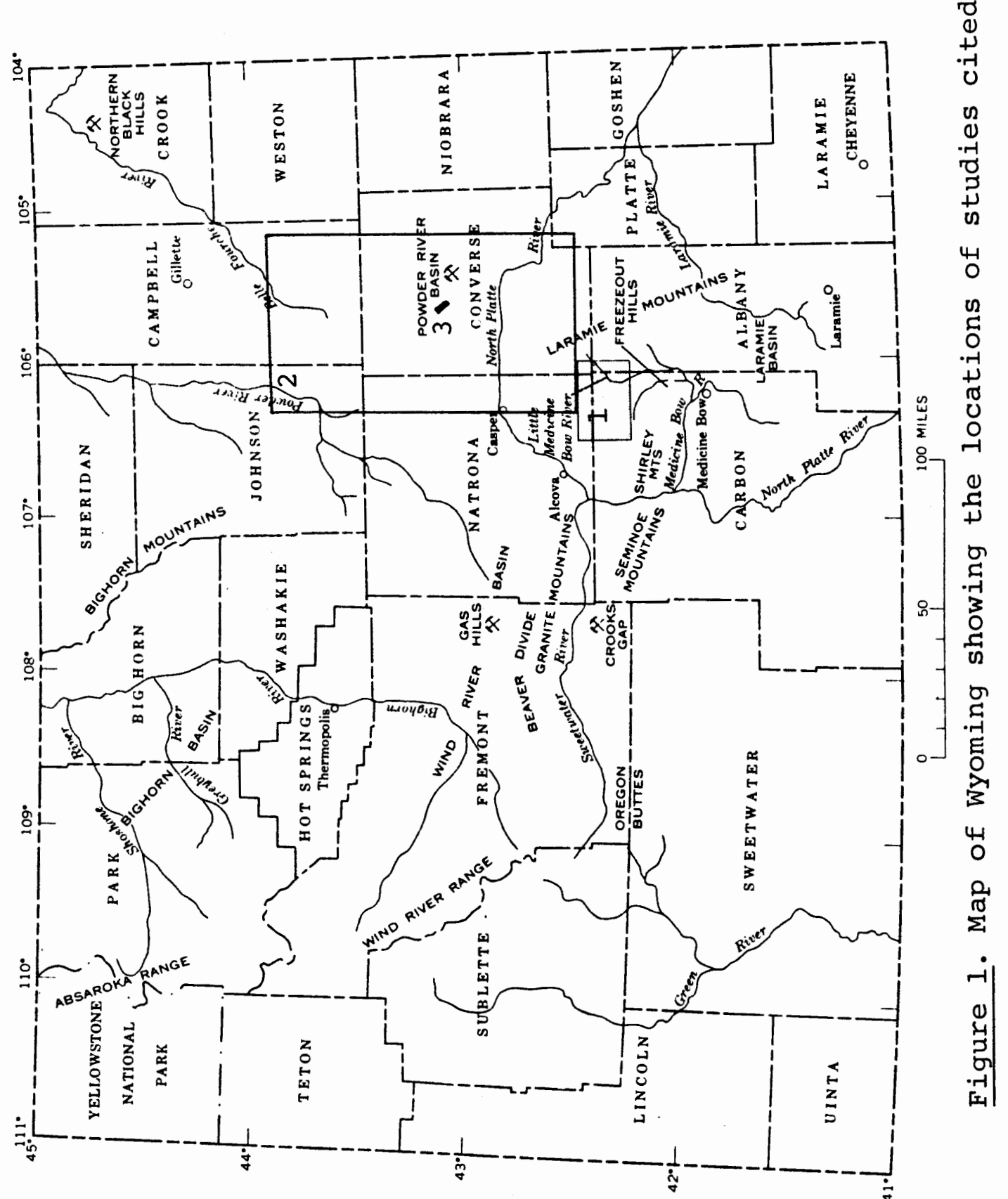


Dakota. The basin is bounded by the Bighorn Mountains on the west, the Black Hills to the east, and the Casper Arch, Laramie Mountains, and Hartville Uplift to the south. Northward the basin is separated from the Williston Basin by the Miles City Arch.

The Dave Johnston Coal Field is located approximately twelve miles north of Glenrock, Wyoming (see Figure 2). The mine is operated under the auspices of the NERCO Mining Company, and extracts coal from the Badger and School coal seams (see Plate I). The mine area is in Converse County, crossing Townships 35 and $36 \mathrm{~N}$, and Ranges 74 and $75 \mathrm{~W}$.

The two coal seams occur in the lower Eocene Wasatch Formation (Denson, Dover, and Osmonson, 1980). The Wasatch, 1000 to 2000 feet thick, comprises loosely consolidated sandstones, siltstones, claystones and coal of continental origin (Project Report 1980; Glass, 1981). The sediments are considered to have been deposited on low lying flood plains, estuaries, sloughs and swamps. Lenticular cross bedded sandstones with interbedded siltstones, claystones and coal beds make up the stratigraphic section in the Dave Johnston Coal Field. Lithologic logs from drill holes within the mine area describe the sandstones as poorly sorted and interbedded with layers of fine-grained sandstones and siltstones. Pyrite is noted as small cubes and "globs" in lithologic logs of reduced (gray) sediments. 


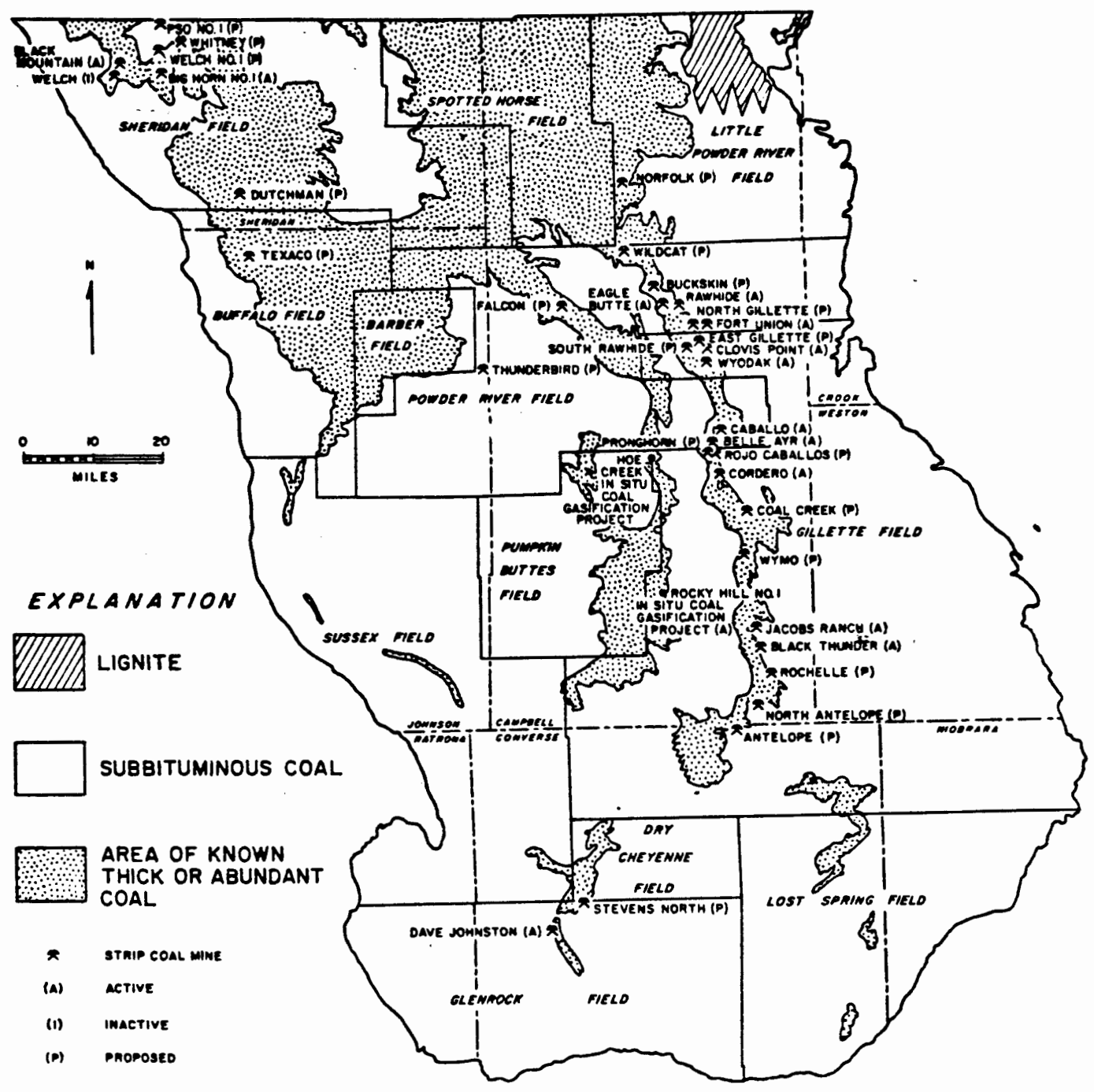

Figure 2. Map of the Powder River Basin showing the location of known coal reserves (from Glass 1981). 
The overburden between the Badger and School coal seams is composed of coarse- to fine-grained sandstones, siltstones and claystones. The depositional environment has been described as a fluvial meander belt system, and the coals are considered to have formed in back swamps of flood basins adjacent to meandering river channels (Ethridge, Jackson, and Youngberg, 1981; Flores and Ethridge, 1981).

\section{OVERVIEW OF SURFACE MINING}

The Badger coal seam is at or near the surface in the mine area. The dip of the coal bed and enclosing strata is very gentle ( 1 to 4 degrees) eastward, toward the axis of the Powder River Basin. Dave Johnston is a surface coal mine and is mined in a box-cut manner. Surface mining entails digging a trench, or cut, through the overburden to the depth of the coal seam which is then removed. Since two seams are economically mineable at Dave Johnston, the process is repeated after the removal of the Badger coal to expose the lower school seam. With each successive cut, the overburden debris (spoil) from the new cut is deposited in the cut previously excavated. Thus the overburden is broken up, transported and dumped for later recontouring and reclamation.

In preparation for mining, exploratory wells are drilled to sample the coal quality and seam thickness in advance of the trench cut. Also sampled is the overburden 
above and between the coal seams. The sample drill cores of the overburden are analyzed for toxic or hazardous materials. Portions of the analyses are done to help pinpoint potential problems in mine reclamation.

\section{PROBLEM AND PROCEDURE}

At the Dave Johnston mine, overburden drill core analyses have shown low $\mathrm{pH}$ values in significant portions of the overburden between the Badger and School coal seams. The acidic nature of the overburden ( $\mathrm{pH}$ values of 3.2 to 5.0) could cause problems during reclamation and may require special handling of the material (Michael Woods, pers. comm., 1981). Vegetation is difficult to re-establish in acidic soils, and there is a potential of ground water contamination during and after the mining process.

The acidic zones of the overburden were shown to be restricted to sandstone units in an in-house study at NERCO during the summer of 1981 (see Plate II). These units are usually orangish yellow, medium- to coarsegrained, limonite stained, poorly to moderately indurated, angular to subrounded sandstones. To the north a gray, well indurated sandstone is found. The gray sandstones consistently have a "normal" $\mathrm{pH}$ range of 5.0 to 8.0 . If these two sandstones are laterally and stratigraphically continuous, presumably they are the same unit. If they are the same, the changes in color and cementation could 
have been caused by some type of weathering, groundwater percolation or mineralizing event.

Several cross sections show the interfingering nature of the yellow and gray sandstones, with the gray sandstone occupying a downdip relationship to the yellow (see Plate III and Figures 3 and 4). During the course of the overburden study at NERCO, several hypotheses to explain the presence of limonite and low $\mathrm{pH}$ zones in the yellow sandstones were discussed. The presence of uranium prospects to the west of the mine area and the known occurrence of uranium mineralization in the Powder River Basin and in the Wasatch Formation, suggested a study of the characteristics of uranium roll front mineralization.

A determination of the stratigraphic relationship between the yellow and gray sandstone was made in this study. Along with the stratigraphic and petrologic examination of drill core data, the chemical and clay mineralogical characteristics were studied. The information obtained through these studies was then examined in an effort to identify the parameters of alteration in the overburden sandstones. A model for alteration was developed and tested against the results of the study. Finally, an effort was made to assess the possible effects of the chemical and physical changes in the overburden on reclamation at the Dave Johnston Coal Field.

The samples used in this study were untreated 


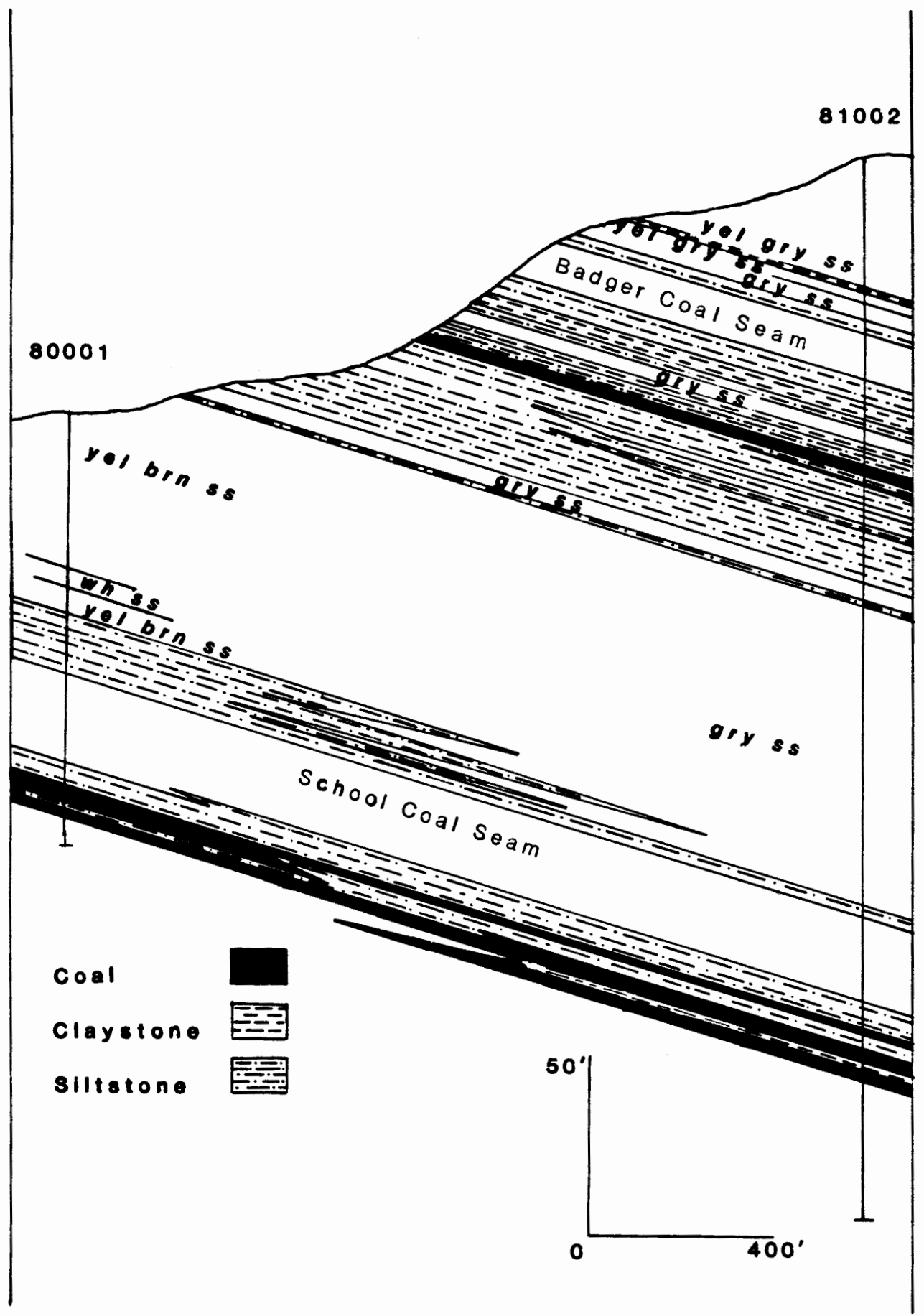

Figure 3. Cross section between drill holes 80001 and 81002 showing the relationship of the strata and the yellow and gray sandstone. 


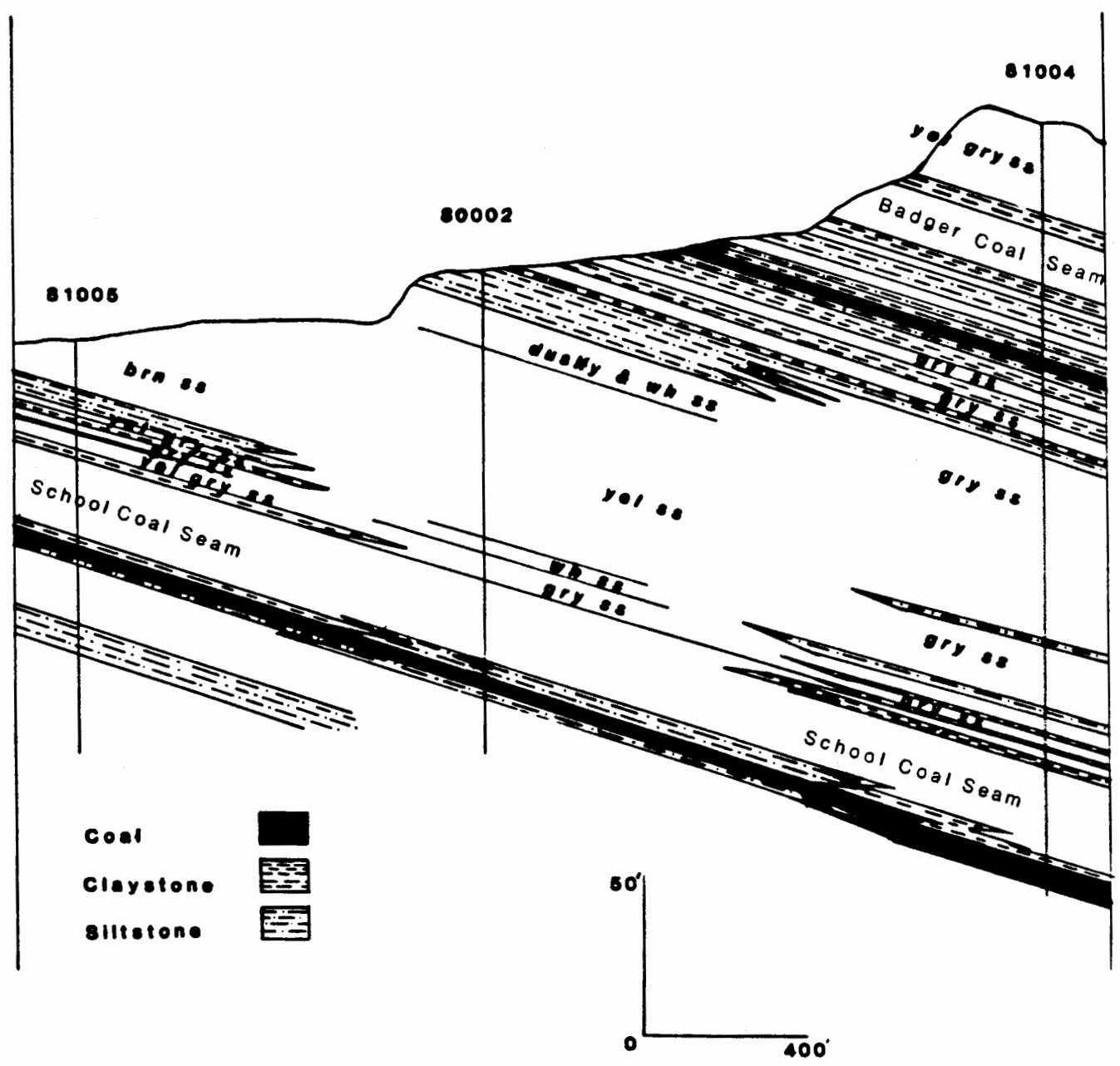

Figure 4. Cross section between drill holes 8:005, 80002 and 81004 showing the relationship of the strata and the yellow and gray sancistone. 
disaggregated portions of the drill core from ten overburden core holes (for locations see Plate I). They were obtained from Energy Laboratories of Billings, Montana. The procedures for overburden sampling is outlined in the Wyoming Department of Environmental Quality, Land Quality Division, Guideline No. 1, and the pertinent portions are presented in Appendix 1. The fifty-six samples used in this study were chosen to provide sample coverage in each drill hole of low and normal $\mathrm{pH}$ zones, and yellow and gray sandstone units.

Procedures used in this study did not require any initial treatment of the disaggregated samples. Specific methods of preparation for a particular study are outlined in the chapter pertaining to the study. Chemical values, including the $\mathrm{pH}$ and ion concentrations, were obtained from the chemical analyses prepared by Energy Laboratories according to the procedures recommended by the Wyoming D.E.Q. (see Appendix 1).

Methods used in this study included $x$-ray diffraction studies of the overburden clays and clay minerals from samples of overburden drill cores. An attempt was made to track metal ion movement in relation to a mineralizing front using data from the overburden analyses of each drill core. Petrographic study of grain mounts from the core samples was used in conjunction with cross sections to try to establish stratigraphic sequence and continuity of the 
overburden units. Scanning electron microscopy was used to study textures on feldspar grains in the yellow and gray sandstones, as well as in identifying clay types. 


\section{CHAPTER 2}

\section{STRATIGRAPHIC CORRELATION}

Stratigraphic control in the Dave Johnston Coal Field is based on logs and cores from wells drilled on two hundred foot centers. The continuity of the Badger and School coal seams, their thicknesses and variations have been mapped with great care. Coal quality is assessed as well, and all of this information is brought together in determining the amount and grade of coal to be mined each year. The "mine plan" is thus the result of an extensive drilling program.

The Wasatch Formation is the result of fluvial sedimentation (Ethridge and others, 1981; Flores and Ethridge, 1981), and the Dave Johnston Coal Field represents a small portion of a very large fluvial system (see Figure 5). The drainage patterns during the Eocene were quite similar to those developed during the Paleocene (Ethridge and others, 1981) as shown in Figure 6. Within a fluvial sedimentary system several facies can exist in a relatively small area, leading to complex intertonguing of sand, silt, clay and carbonaceous layers (see Figure 7). Depositional models developed by Ethridge and others (1981) and by Groenewold, Rehm, and Cherry (1981) illustrate how meandering and 


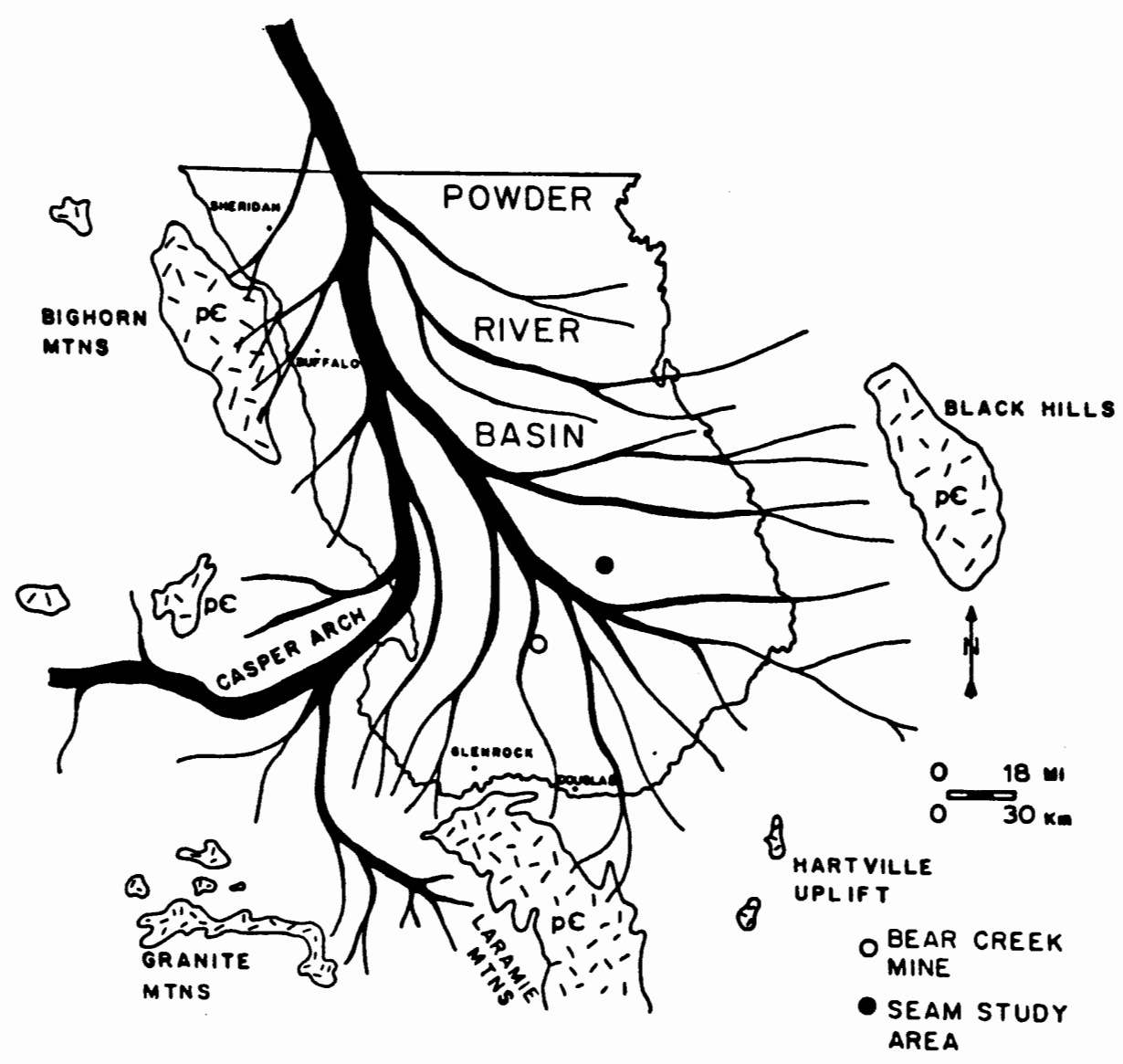

Figure 5. Interpretive map of Eocene paleogeography of northeastern Wyoming suggesting a general drainage pattern for wasatch streams. The southeastern portion of the Powder River Basin is dominated by floodbasin deposits (crevasse splay, swamp, and lake) and meandering channels of tributary streams (from Ethridge and others 1981). 


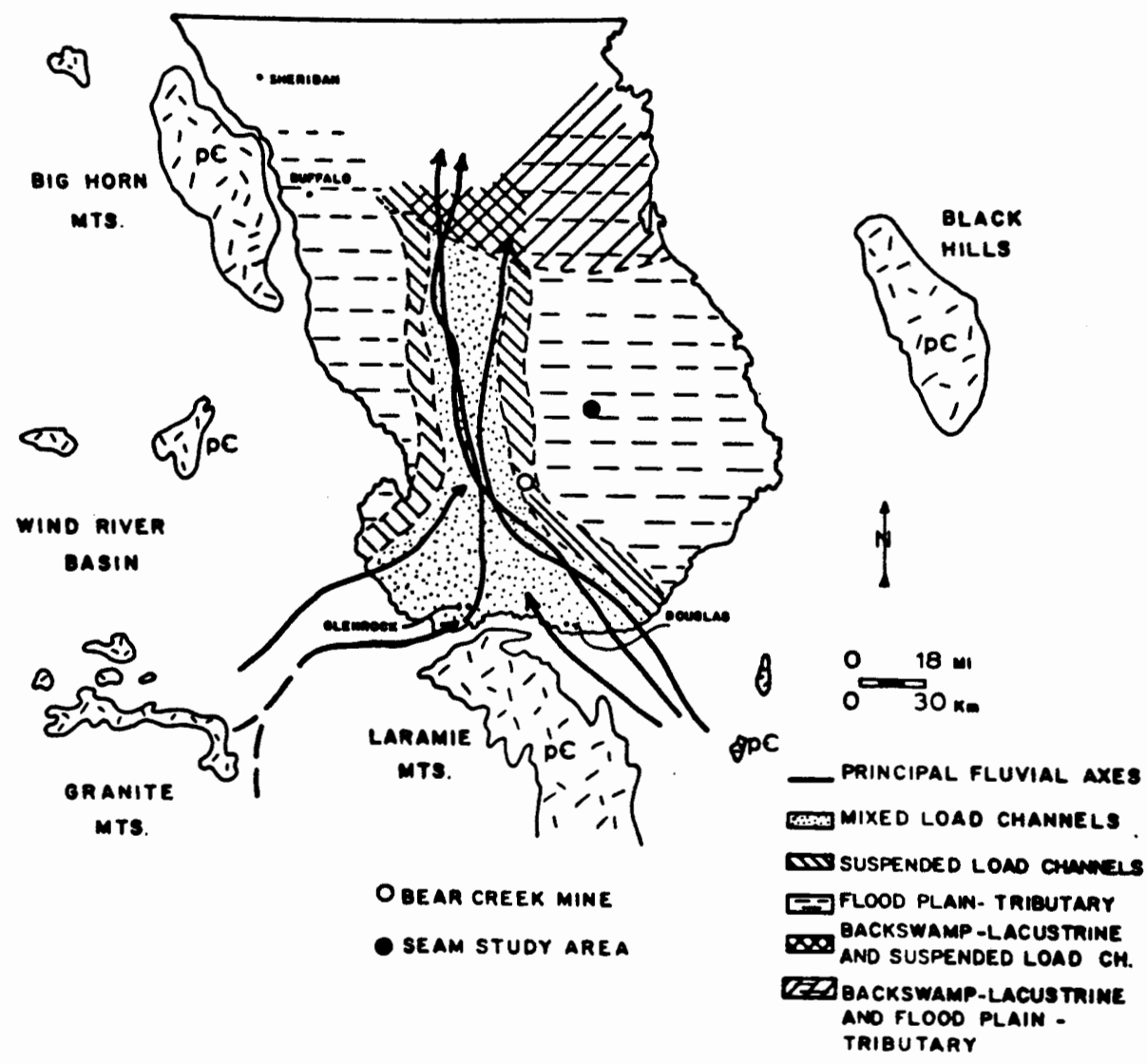

Figure 6. Inferred depositional system and subsystems for the upper part of the Fort Union Formation (Paleocene). The depositional setting of the Eocene Wasatch is thought by Ethridge and others (1981) to have been quite similar to the floodplain-tributary system shown here (from Ethridge and others 1981). 


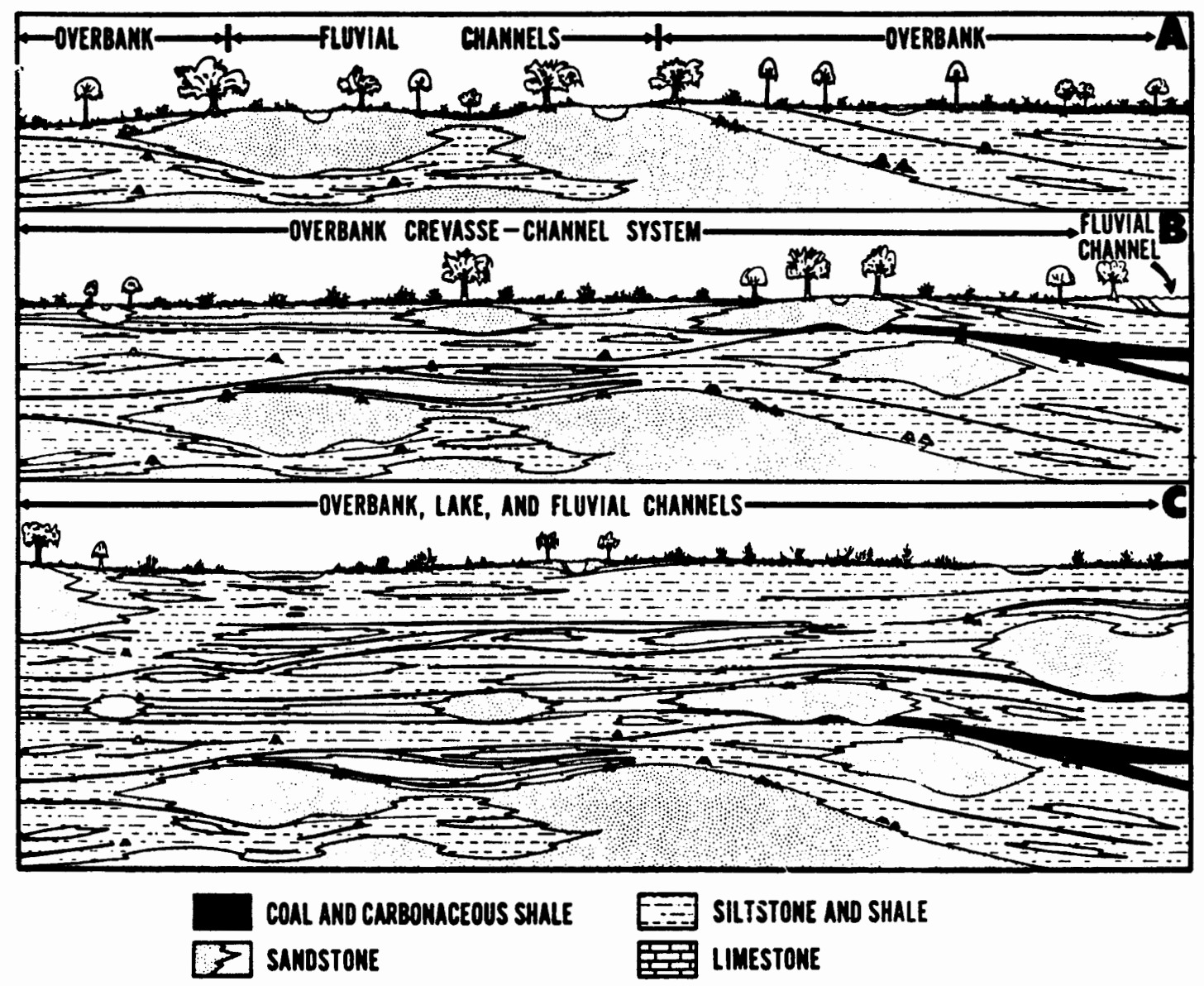

Figure 7: Complex lithogenetic model developed for a fluvial-channel-dominated facies in a portion of the Tongue River Member of the Fort Union Formation (from Flores 1981). 
channeling by a stream, coupled with poorly drained swamp areas, can produce an intricate stratigraphic section of sandstone, siltstone, claystone and coal. Their models are shown in Figures 8 and 9. Cross sectional views within the Dave Johnston Coal Field show remarkable agreement with those envisioned by Ethridge and others (1981) and with their depositional model. The longitudinal cross section (Plates II and III) as well as Figures 3 and 4 , record the meandering of a stream system between the deposition of the School and Badger coal seams. The silt and claystone units represent the filling in of meanders, while the absence of fine-grained units in Overburden Drill Hole 80002 corresponds to a crevasse splay deposit.

To establish the continuity of the sandstones in this study, the data from ten overburden drill holes were used to draw cross section views, both parallel and perpendicular to strike, establishing spatial relationships. Two transverse cross sections readily show the stratigraphic relationships of the yellow and gray sandstones. The gray sandstone is downdip, to the east, from the yellow. The relationships are not as clear on the longitudinal section (Plate II), but a sandstone layer can be followed throughout the section at approximately fifty feet above the top of the School seam. Plate II was drawn using the top of the school seam as the datum plane and better illustrates the continuity of the sandstone above the coal seam. The 


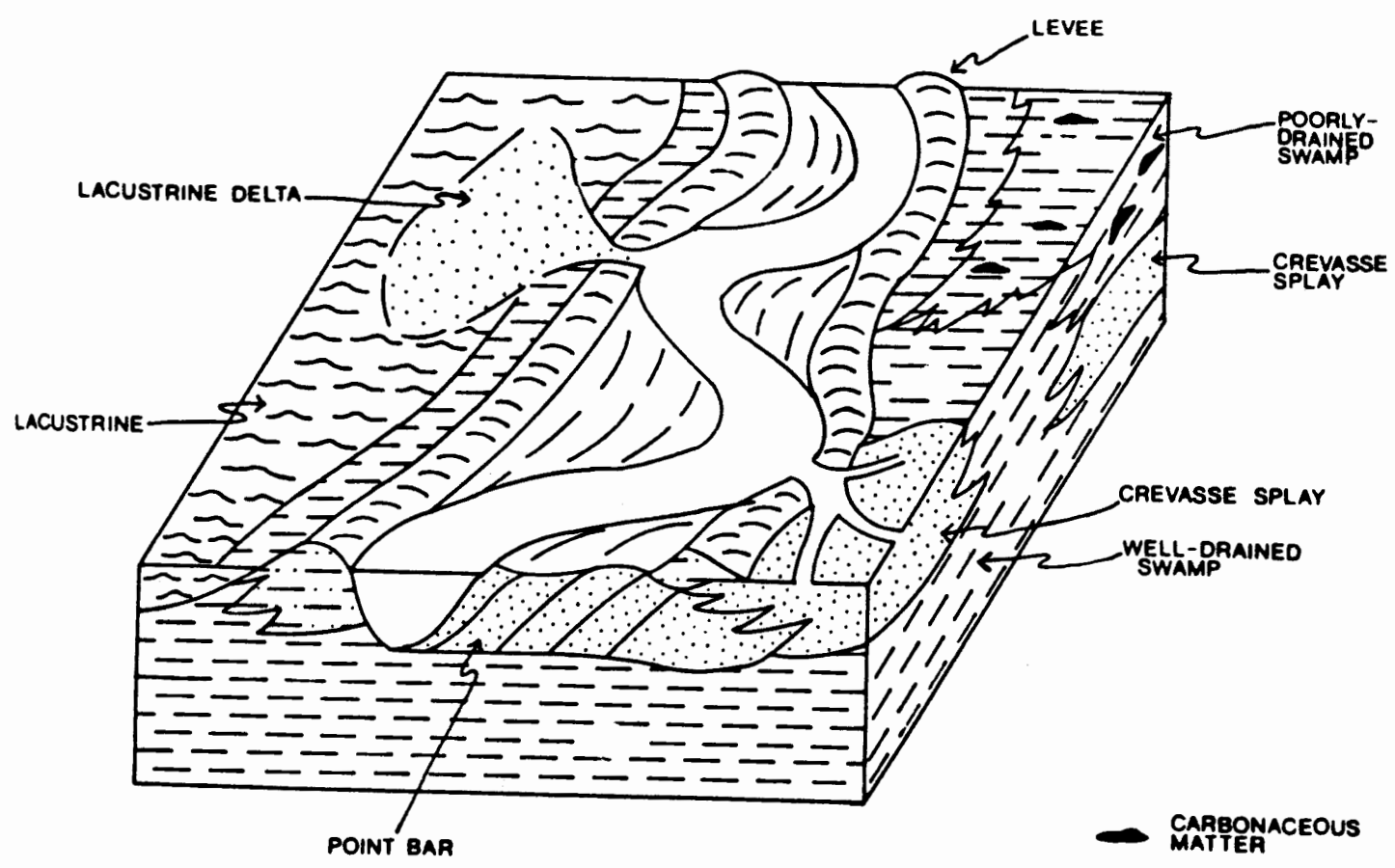

Figure 8. Schematic reconstruction of inferred depositional environments in the tributary subsystem, lower wasatch Formation, in the SEAM Study Area of Wthridge and others (1981), northeast of the Dave Johnston Coal Field. Sketch shows the intricate relationships of sand, silt, clay and carbonaceous material that develop in a fluvialchannel environment (from Ethridge and others 1981). 


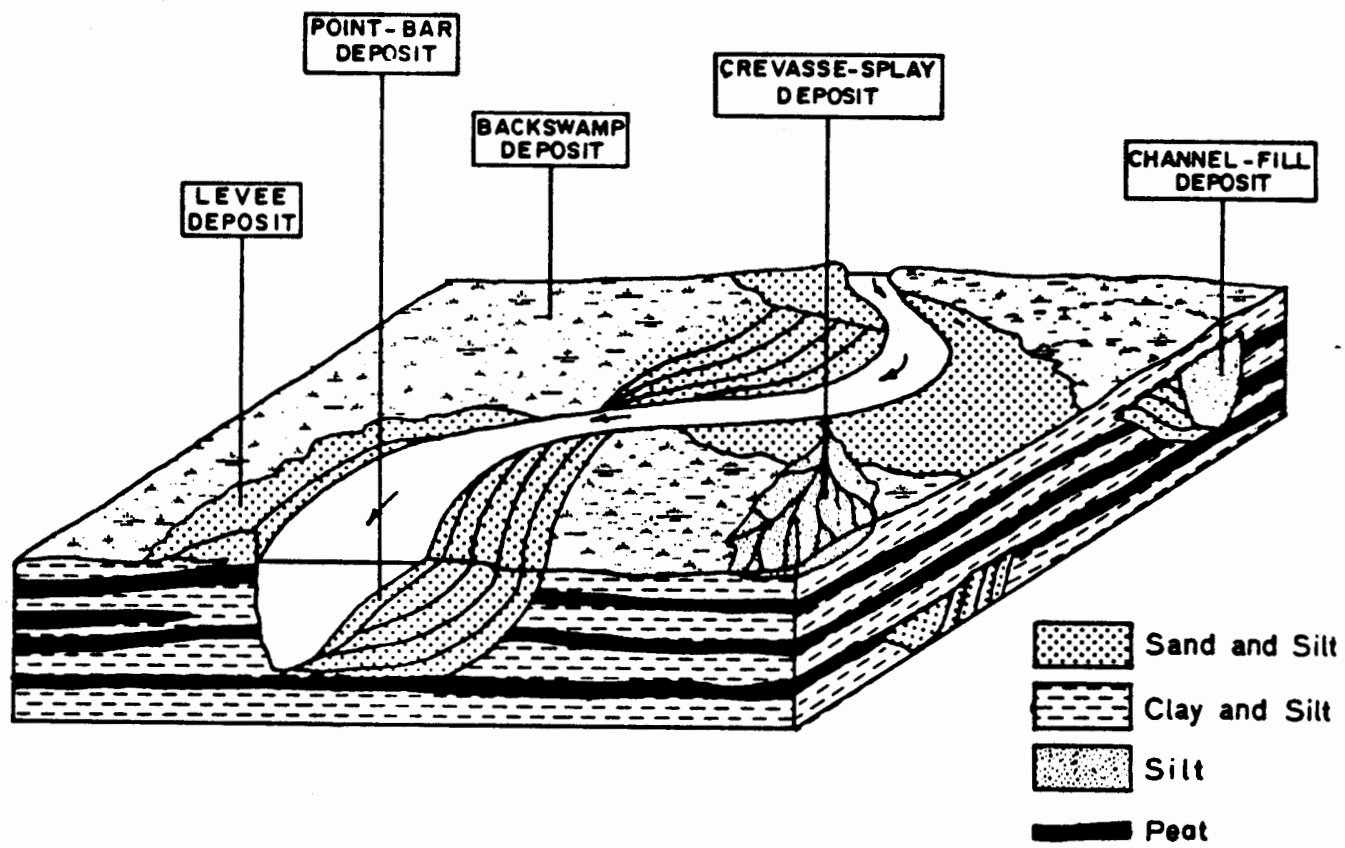

Figure 9. Depositional model developed for lowgradient meandering streams in alluvial flood plain environments (from Groenewold and others 1981). 
change in sandstone color in the longitudinal sections probably is the result of both downdip movements of oxidizing solutions and weathering (oxidation) of the sandstones due to erosion of the fine-grained capping layers (see Harshman, 1972).

\section{PETROGRAPHY}

Sixteen samples were chosen for preparation of grain mounts, in hopes that a petrographic examination would further establish the uniformity and continuity of the sandstone beds between the School and Badger coal seams. Each sample was sieved and divided into 1-2 phi and 2-4 phi size classes. The sands are predominantly quartz and feldspar, with a few opaques. The quartz grains were chosen as easily identifiable and were counted as rutilated quartz, recrystallized quartz and chert, and other quartz. Results of the grain mount study are included in Table 1. Pyrite cubes were identified under reflected light in several of the grain mounts of the gray sandstones, but not in the mounts from the yellow samples.

Microscopic examination of the grain mounts did show rutilated quartz in all samples, with an average proportion of 138. Recrystallized quartz and chert also gave a fairly steady value of about 108 in all samples. The feldspar counts varied considerably, with a corresponding inverse variation in the amount of limonite and limonite coated fragments in a given sample. 


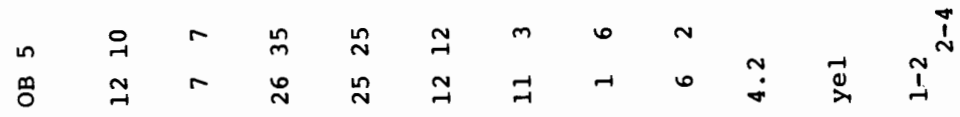

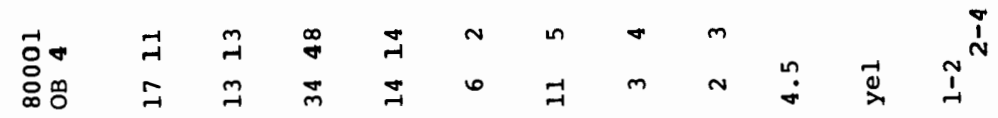

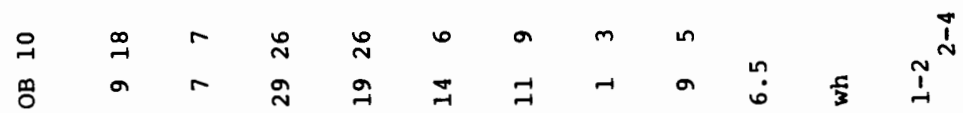

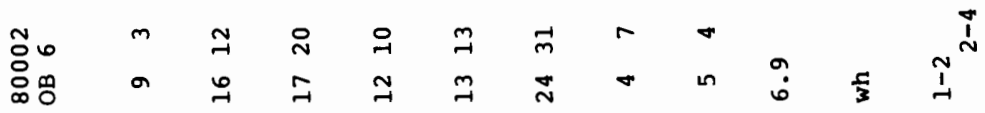

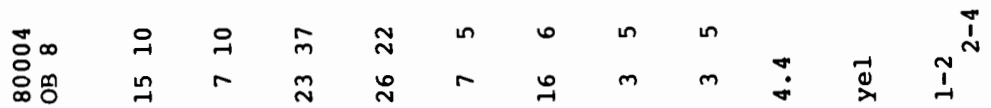

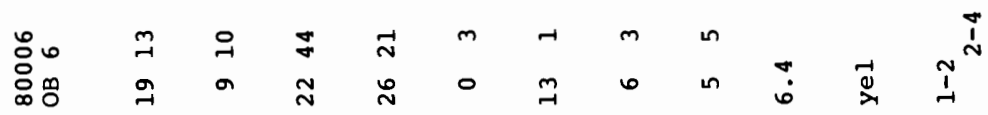

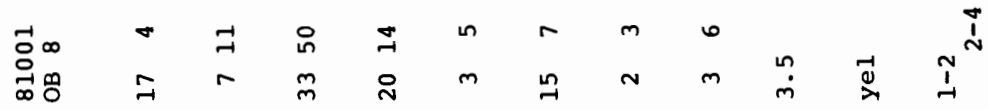

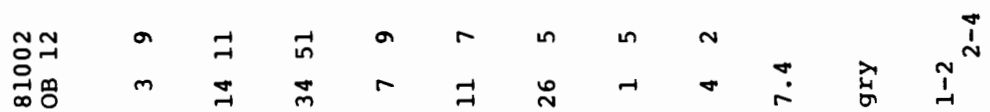

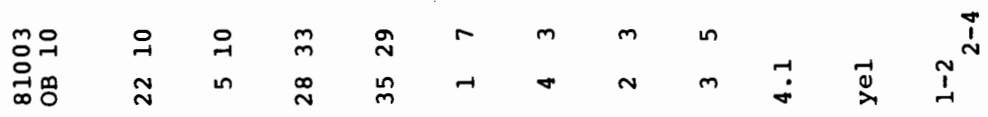

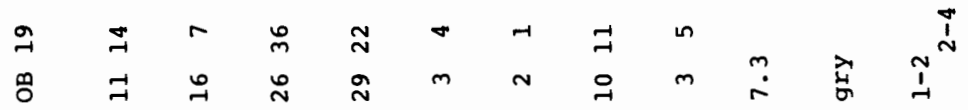

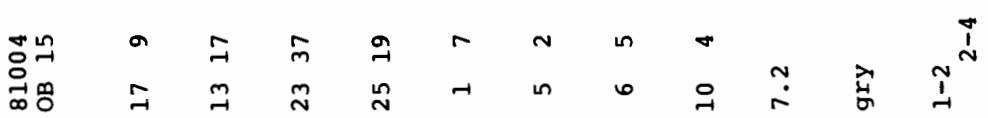

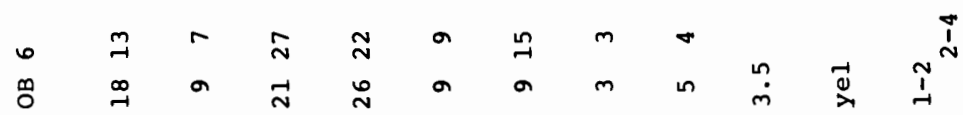

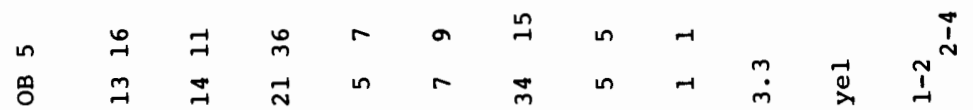

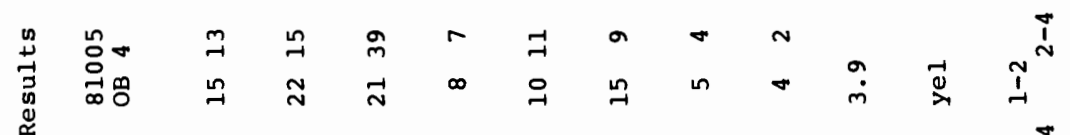

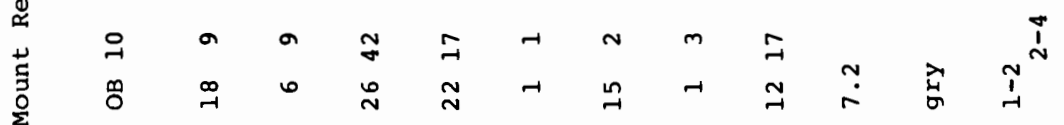

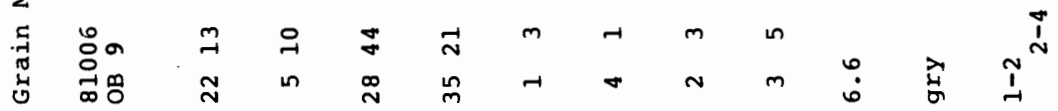

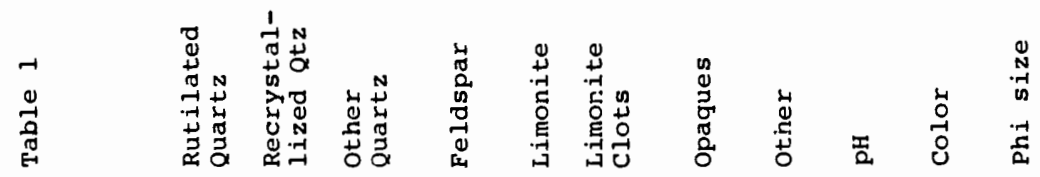


The grain mounts indicate very similar, if not the same, provenance for the sandstones. Since whole rock samples were not available for this study, it was not possible to do more detailed petrographic studies of the sandstones which might have served to better illustrate the petrologic equivalence of the various samples.

However, the stratigraphic control and lateral continuity of the affected sandstones can be easily seen in the cross sections perpendicular to strike. In the 1400 feet separating Overburden Drill Hole 80002 and 81004 (see Figure 4), the drillhole data does not show any abrupt changes in lithology, but rather lithologies that correspond very closely. The major changes in the sandstone unit between the coal seams are in the color and $\mathrm{pH}$ values. The same changes are found in the same sandstone unit between holes 80001 and 81002 as seen in Figure 3 .

The decrease in feldspars in some of the samples shows the effect of an acidic environment. The feldspar grains that are recognizable in these grain mounts are corroded and heavily coated with limonite and clay. Several clots were probably feldspar grains, but are now indistinguishable clumps of limonite and clay. Recognizable feldspar grains from these samples also show etching along cleavage traces. Samples taken from yellow sandstones show a decrease in feldspars and an increase in the number of grains identified as limonite and limonite clots. The 
samples taken from gray sandstones have a greater percentage of feldspars, as well as fresher, less corroded feldspar grains (see Figure 10). The gray sandstones were not subjected to acidic or oxidizing changes in environment. 


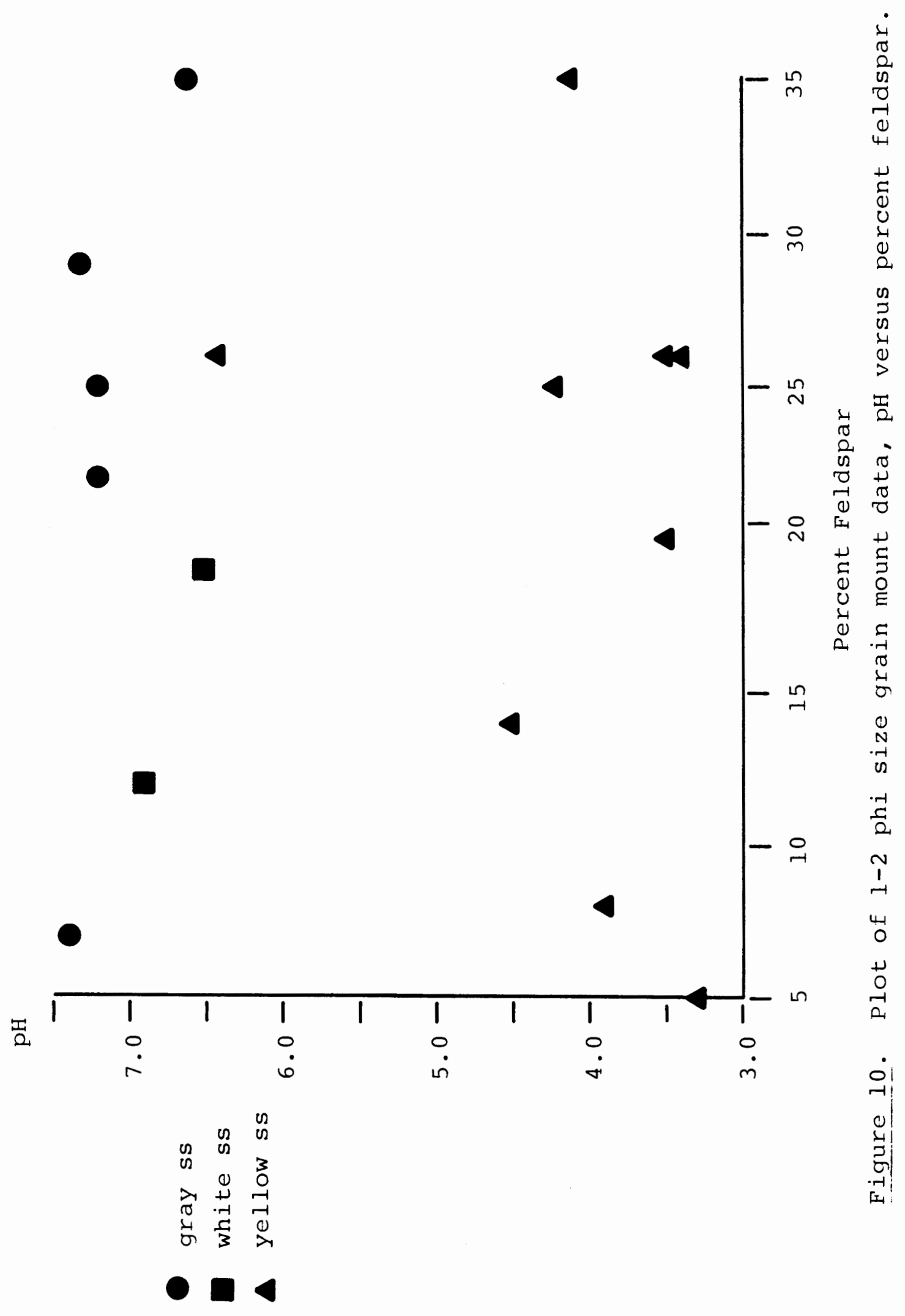


CHAPTER 3

\section{CIAY MINERALOGY}

Analysis of the clays in the overburden at Dave Johnston Coal Field was made by $x$-ray diffraction studies of fifty-six samples from ten different overburden drill holes. The samples, which were received from Energy Laboratories of Billings, Montana, were portions of disaggregated untreated overburden drill cores.

The purpose of the clay analysis was to determine whether or not any changes in clay mineralogy could be found that could be correlated to the oxidized and reduced sandstones. A change in clay minerals could be a response to the $\mathrm{pH}$ and the Eh environment produced by the mineralizing solution as it moved through the sandstones.

Preparation of the samples for $x$-ray diffraction was simple and straightforward. The samples were not subjected to any pre-treatments, such as iron removal or calcium saturation, since the samples gave quite satisfactory peaks without such treatments. The samples were agitated in distilled water using a sonic probe and centrifuged at $750 \mathrm{rpm}$ to settle out the greater than 2 micron size fraction. The supernatant was then treated with DMSO as a check for swelling clays, and for these samples the supernatant was dropped 
onto clay tiles positioned over evaporating funnels. The DMSO was then dropped onto the clays.

The $x$-ray diffraction patterns for the samples on the glass slides were run from 2 to 28 degrees 20 , which gives an effective range of 20 to 3 Angstrom spacing in the crystal lattices. The slides were then baked at 600 degrees $C$ for one hour and $x$-rayed again. After the initial $x$-ray studies were analyzed, twenty samples were chosen for DMSO treatment to better categorize the clay minerals. Two mounts were made of each of the twenty, one on glass as a control, and one on clay tile which was DMSO saturated. The second set of diffractograms were run from 30 A to $5.90 \mathrm{~A}$, since the clay tiles begin to give interference peaks at $4.9 \mathrm{~A}$, and the smectite and chlorite peaks occur between $29.4 \mathrm{~A}$ and $6.80 \mathrm{~A}$. The second set of clay mounts were also baked at 600 degrees $C$ for one hour and $x$-rayed after cooling.

Tabulation of the peaks recorded on the diffractograms is presented in Appendix 2. Identification of the clays by $x$-ray peak and d-spacing were done using data from Brown (1961), Carroll (1970), Grim (1962), and Thorez (1976).

The $x$-ray studies do show a different clay mineralogy between those samples with a normal pH range between 5 and 9, and those samples with a $\mathrm{pH}$ value of less than 5. To check these results, twenty samples were remounted and 
saturated with DMSO. The results were consistent and yielded even better resolution of some of the clay peaks. Smectite (montmorillonite), kaolinite, illite, alpha quartz, and feldspar peaks were identified in all fifty-six samples. The illite peaks were intensified after baking by the collapse of the smectites from a $14 \dot{A}$ spacing to a $10 \AA$ spacing. The kaolinite peaks were lost after baking, while the alpha quartz and feldspar peaks remained stable.

The appearance of a $13.5 \dot{A}$ to $14 \dot{A}$ peak after baking confirms the presence of chlorite in several of the samples. Thirty samples show a $14 \AA$ peak after baking, but three of those are probably due to incomplete collapse of the montmorillonite (samples 80002-OB 6, 81002-OB 5, and 81004-OB 6). All three samples were $x$-rayed a second time with DMSO treatment and two did not show a $14 \AA$ peak after baking, while $80001-0 b 6$ had a poorly developed $14 \dot{A}$ peak. However, the other twenty-seven samples did show a good $14 \AA$ peak after baking. (After baking the $14 \dot{A}$ peak of chlorite is intensified while its $7 \dot{A}$ peak is 1ost, as is the $14 \AA$ peak of the smectite clays (Thorez, 1976). Twelve of those samples showing good $14 \dot{A}$ peaks after baking were remounted and treated with DMSO and re-x-rayed.

The overburden core hole samples which show chlorite peaks all have a normal $\mathrm{pH}$ range as determined by the analysis done on the cores by Energy Laboratories. Those samples with a pH value below 5.0 do not show a $14 \dot{A}$ peak 
after baking. Samples 81002-OB 5 and $81003-O B$ have a low $\mathrm{pH}$ value and show $14 \AA$ peaks after baking in the initial $x$-ray study. Subsequent remounting and $x$-raying does not show a chlorite peak, either on the glass slide or on the DMSO treated clay tiles. The remaining samples, those with a $\mathrm{pH}$ value in the normal range but without a chlorite peak are either samples of siltstone, samples of white sandstone, or they represent mixtures of gray and yellow sandstone in the core sample.

The absence of chlorite in the siltstone samples may be due to the fact that chlorite did not form in those sediments during diagenesis. Triplehorn (1970) argues persuasively that chlorite probably does not form authigenicly in siltstone and claystone due to the decreased permeability of these sediments. The decrease in permeability may prevent circulation of waters carrying excess silica and free ions that would promote the formation of chlorite (see also Wilson and Pittman, 1977).

The mixed sandstone samples probably would have shown the chlorite-pH association had the cores been split on lithology or color changes rather than on ten foot core lengths. When samples were taken in ten foot lengths, the boundaries between the altered and unaltered sandstones were not observed. As a result, the samples tend to yield moderate $\mathrm{pH}$ values due to the mixing of the zones, as seen in the values for 81006 (see Plate II). The white sand- 
stones present an anomalous situation. The most reasonable answer is that the low $\mathrm{pH}$ values are tied to the presence of limonite in the samples, and absence of limonite, even in altered sandstones, accounts for both the lack of yellow color and the normal $\mathrm{pH}$ range in those samples.

Chlorite forms authigenicly under slightly alkaline conditions (Millot, 1970) developed during diagenesis (Wilson and Pittman, 1977). A change from basic to acidic in the circulating groundwaters can lead to the destruction of chlorite (Millot, 1970; Triplehorn, 1970). The Eh of solutions also influences the formation or degradation of ferrous iron, and thus of ferriferous clays such as chlorite (Millot, 1970). The oxidation of ferrous iron would disrupt the crystal lattice, facilitating the loss of oxygen and of the central cation in the octahedral layers in the chlorite structure. Millot (1970) and Birkland (1974) call this process degradation and it can result in the eventual formation of montmorillonite from chlorite (see Figure 11).

All fifty-six samples did have good smectite (montmorillonite) peaks. Montmorillonite clays often have charge deficits due to the partial replacement of aluminum in the octahedral layers. The charge deficits are balanced by exchangeable interlayer ions, with sodium and calcium being the most frequent cations (Millot, 1970). Differentiation between sodium and calcium rich montmorillonite clays is made by examining the sharpness of the $14 \dot{A}$ peak 
Degradation

Illite $\rightleftharpoons I-$ Vmixed layer $\rightleftharpoons$ vermiculite $\rightleftharpoons \mathrm{V}-\mathrm{M}$ mixed layer $\rightleftharpoons$ montmorillonite Biotite $\rightleftharpoons$ hydrobiotite $\rightleftharpoons$ (Tri)vermiculite $\rightleftharpoons$ (Tri)montmorillonite

Biotite $\rightleftharpoons$ chlorite $\rightleftharpoons \mathrm{C}-\mathrm{V}$ mixed layer $\rightleftharpoons(\mathrm{Di})$ vermiculite $\rightleftharpoons(\mathrm{Di})$ montmorillonite

Aggradation

Figure 11. Degradation scheme for montmorilIonite clay (from Millot 1970). 
on x-ray diffractograms (Brown, 1961). Further determination of the presence of $\mathrm{Na}^{+}$or $\mathrm{Ca}^{+}$can be made by calcium saturation of samples thought to be $\mathrm{Na}^{+}$rich and comparing treated and untreated diffraction patterns. If a sample is $\mathrm{Na}^{+}$rich a calcium saturation should sharpen the $14 \dot{A}$ peak (Robert Van Atta, pers. comm., 1983).

of the fifteen low pH samples, twelve of them show very sharp, well-defined $14 \AA$ peaks, corresponding to $a$. $\mathrm{Ca}^{++}$rich interlayer (see Figure 12). The same proportion (808) of the normal $\mathrm{pH}$, or gray sandstone samples show diffuse, broad shouldered $14 \AA$ peaks (see Figure 13). Two gray sandstone samples were calcium saturated to see if the broad peaks could be tightened. As Figures 14 and 15 show, the calcium treatment did change the patterns, tightening the $14 \AA$ peak.

The $x$-ray analysis shows the presence of sodium rich montmorillonite in the downdip, unaltered sandstones. In the altered, yellow sandstone samples the sodium has been replaced by calcium, giving a sharper $14 \AA$ peak. The replacement of sodium implies that calcium is more available in the oxidized sandstones. Dissolution of calcite in the acidic environment of the yellow sandstone provides $\mathrm{Ca}^{++}$ for substitution in the interlayer positions of the montmorillonite clays. 


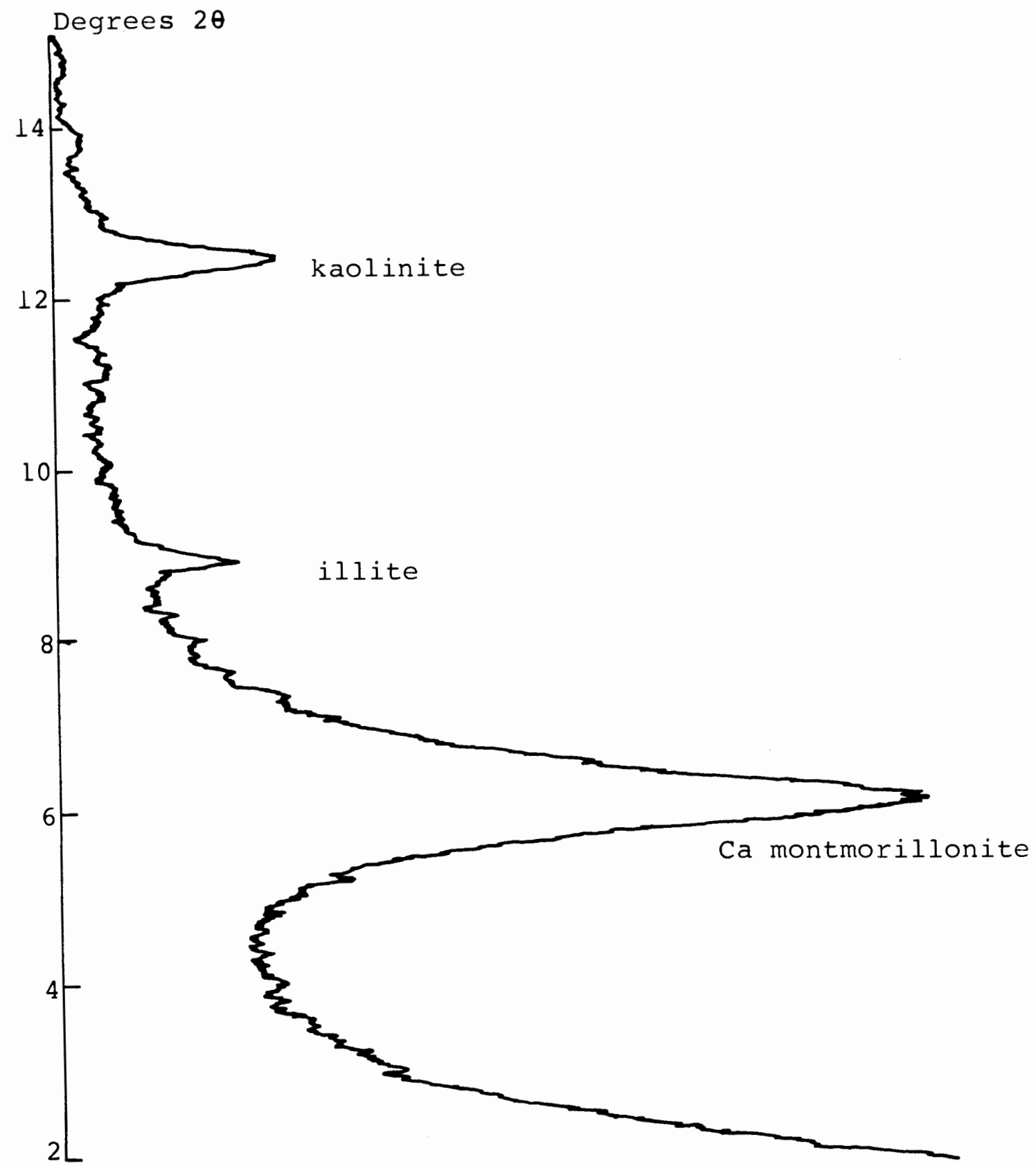

Figure 12. Diffraction pattern for sample 81001-OB 8 showing a sharp montmortillonite peak. 


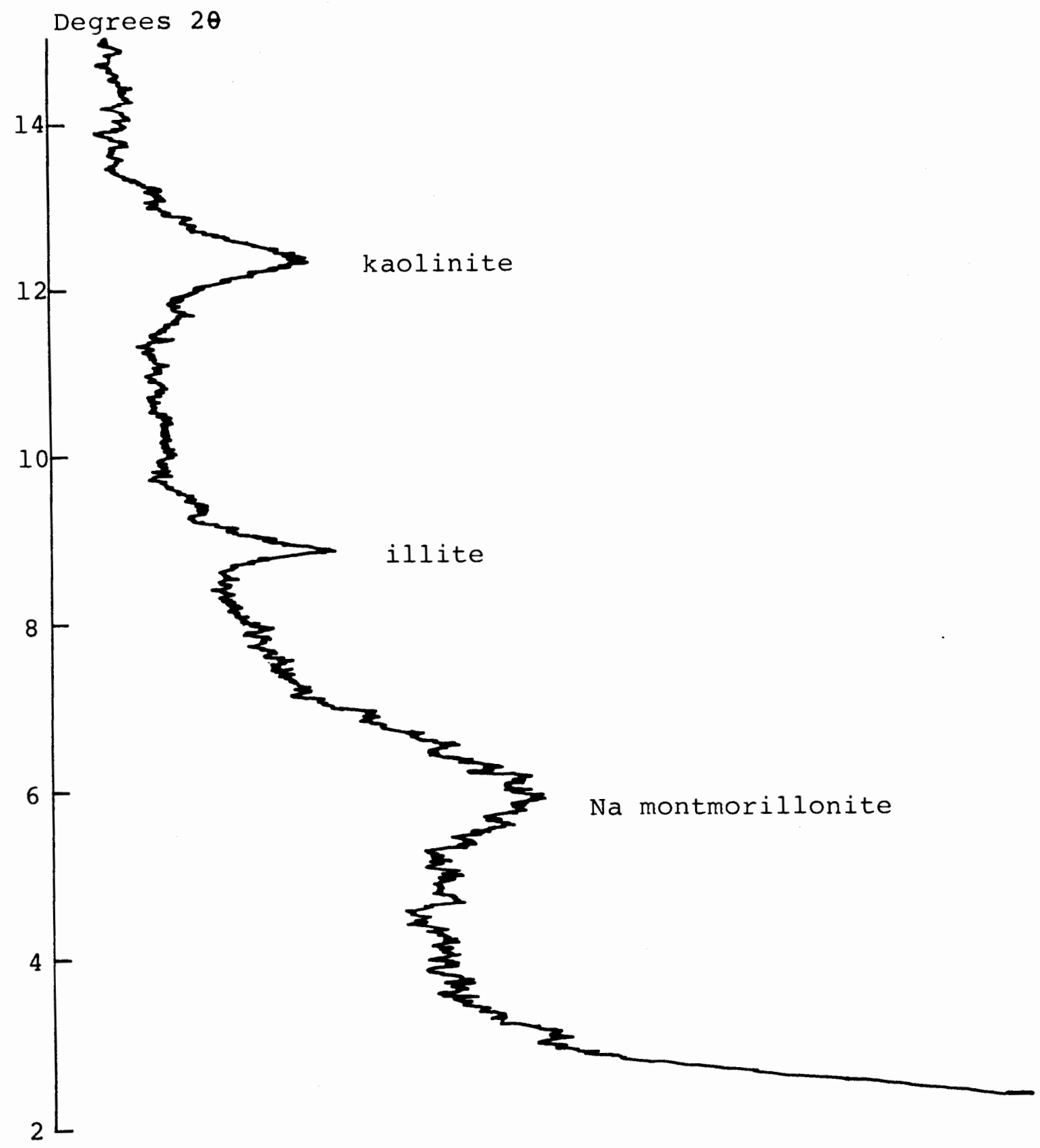

Figure 13. Diffraction pattern for sample 81006-OB 14 showing a broad montmorillonite peak. 


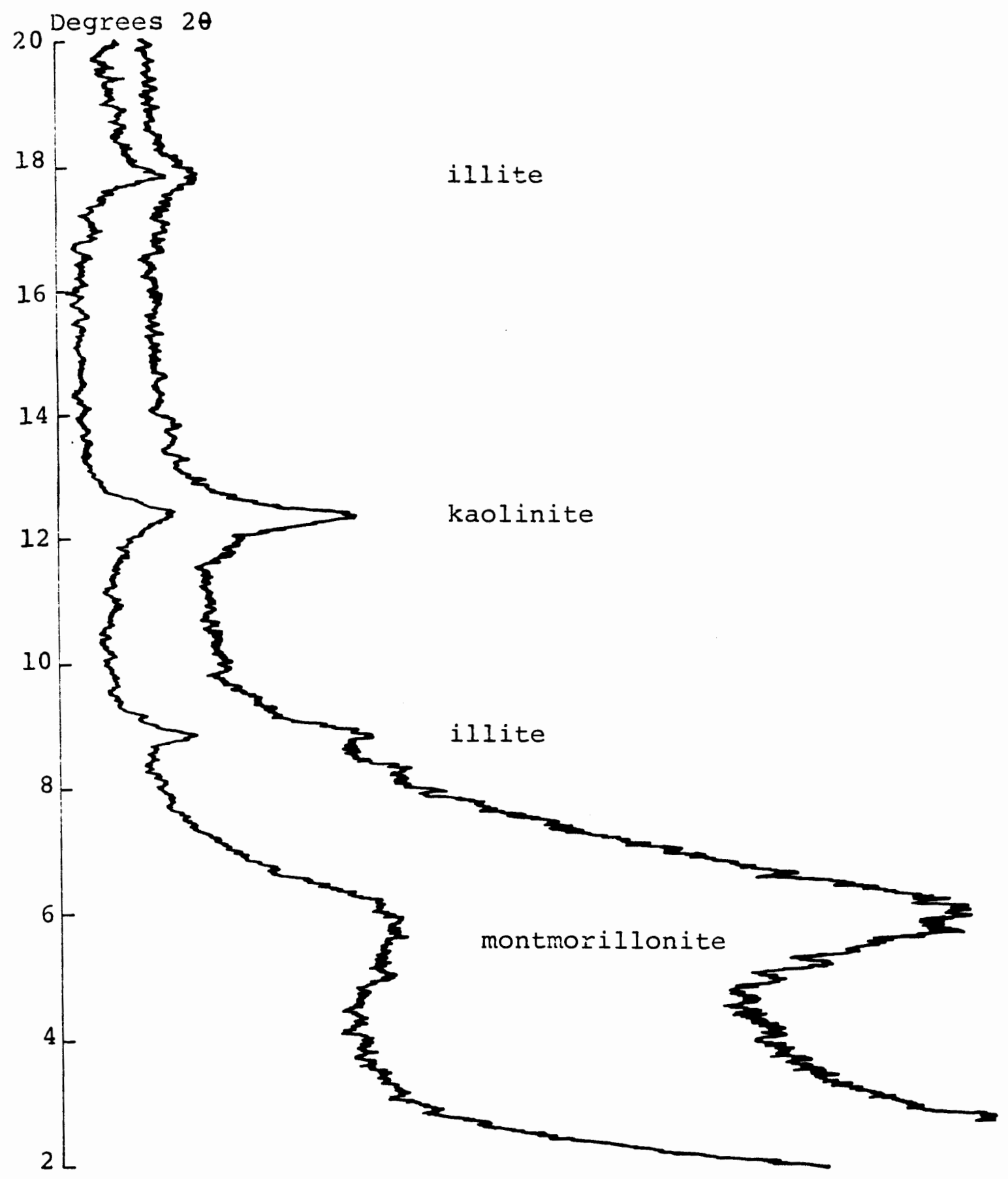

Figure 14. Comparison of untreated and $\mathrm{Ca}^{++}$saturated diffraction patterns for sample 81006-OB 5 , the $\mathrm{Ca}++$ treated pattern is on the right. 


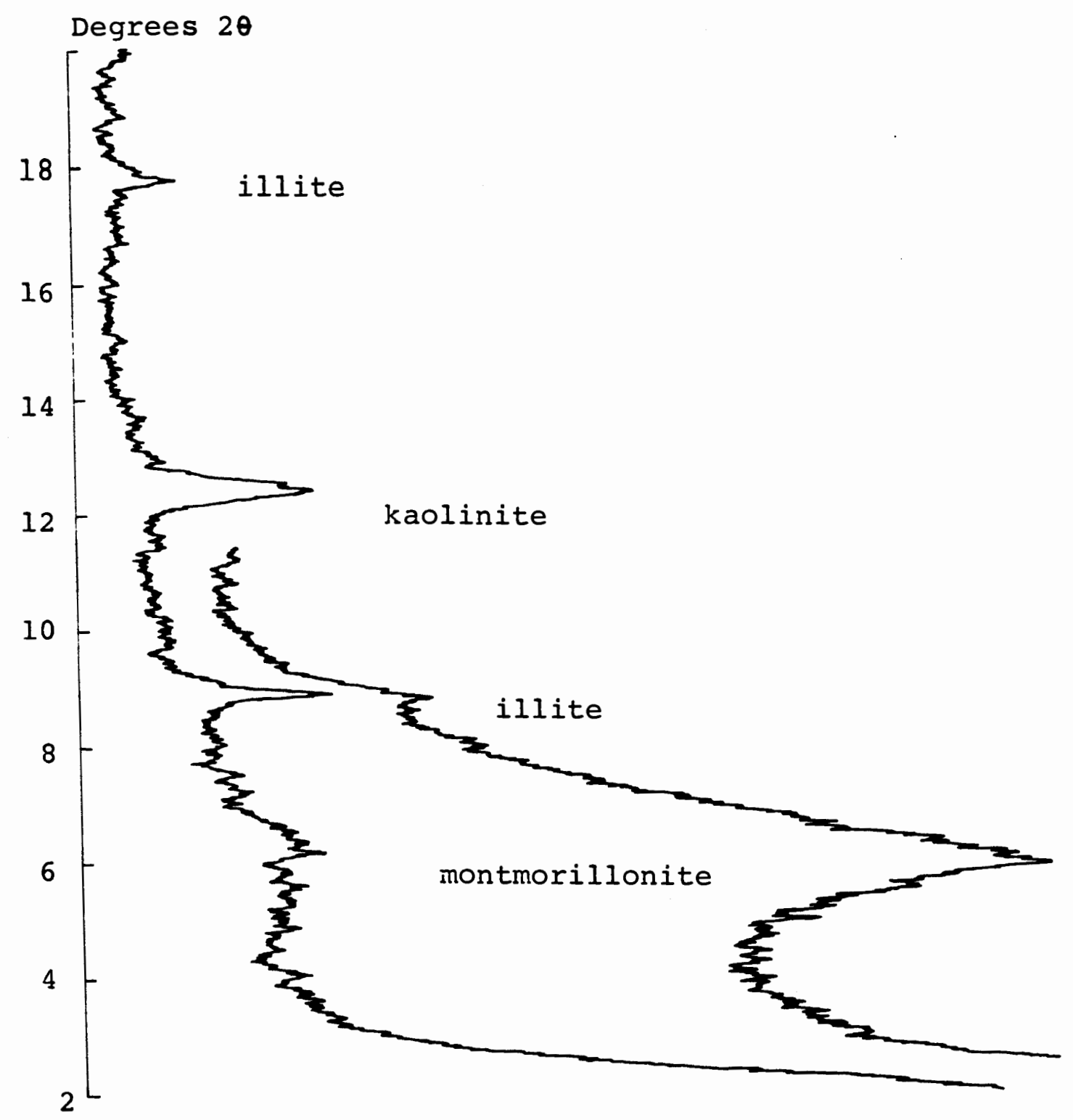

Figure 15. Comparison of untreated and $\mathrm{Ca}^{++}$ saturated diffraction patterns for sample 80004$O B 10$, the $\mathrm{Ca}$ treated pattern is to the right. 
CHAPTER 4

\section{ION DISTRIBUTION}

Chemical analyses of the overburden cores provides some data on metal ion distribution in the Dave Johnston Coal Field. These analyses were studied to determine if the distributions were related in any mannex to the altered-unaltered areas. The analyses provided values for $\mathrm{Cu}$, Se, Mo, Ca and calcite, and these values were plotted on cross sections (see Figures 16 and 17 and Plate III). The data available for the sandstone in the Dave Johnston Coal Field do not show any strong correlations between ion distribution and proximity to the areas of yellow-to-gray interface. There is an increase in the metal ion concentration in the siltstones and claystones of the overburden, which is most likely due to an increase in the clay size particles which in turn provide more sites for ion substitution.

The selenium values do not show any trend between the altered and unaltered sandstones, and copper, molybdenum and calcium also fail to show definite correlations. However, between drill holes 80001-OB and 81002-OB some changes in ion concentration are seen. Drill hole 80001-OB is located westward and updip from 81002-OB. The 

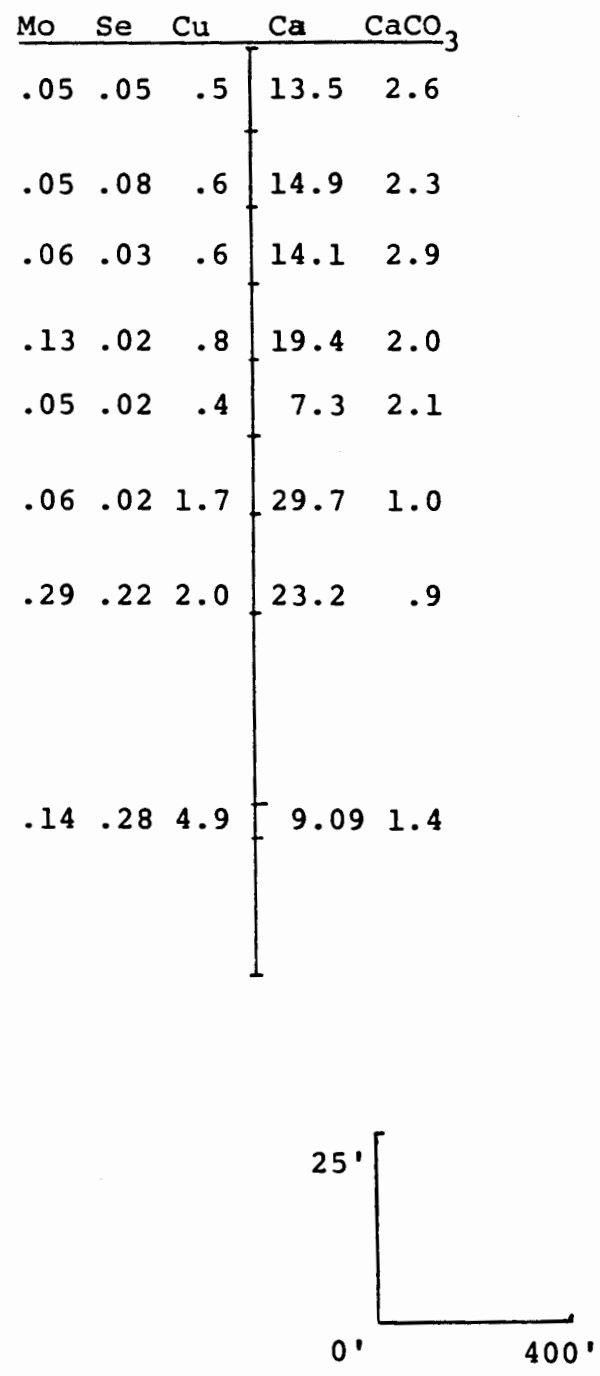

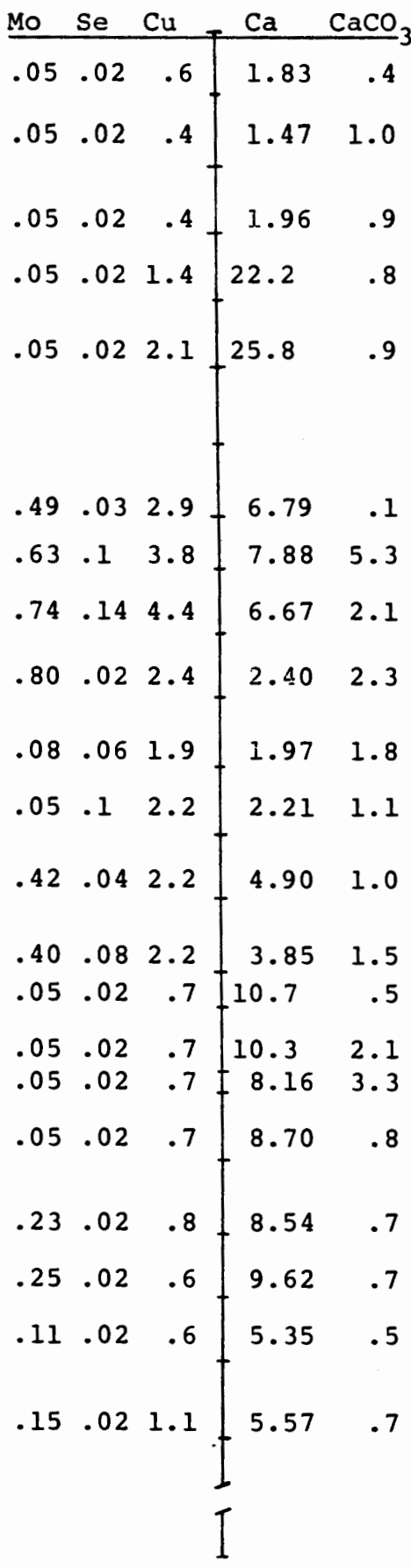

Figure 16. Ion distribution for drill holes 80001 and 81002. Refer to Figure 3 for lithologies and Appendix 3 for chemical data. 
81005

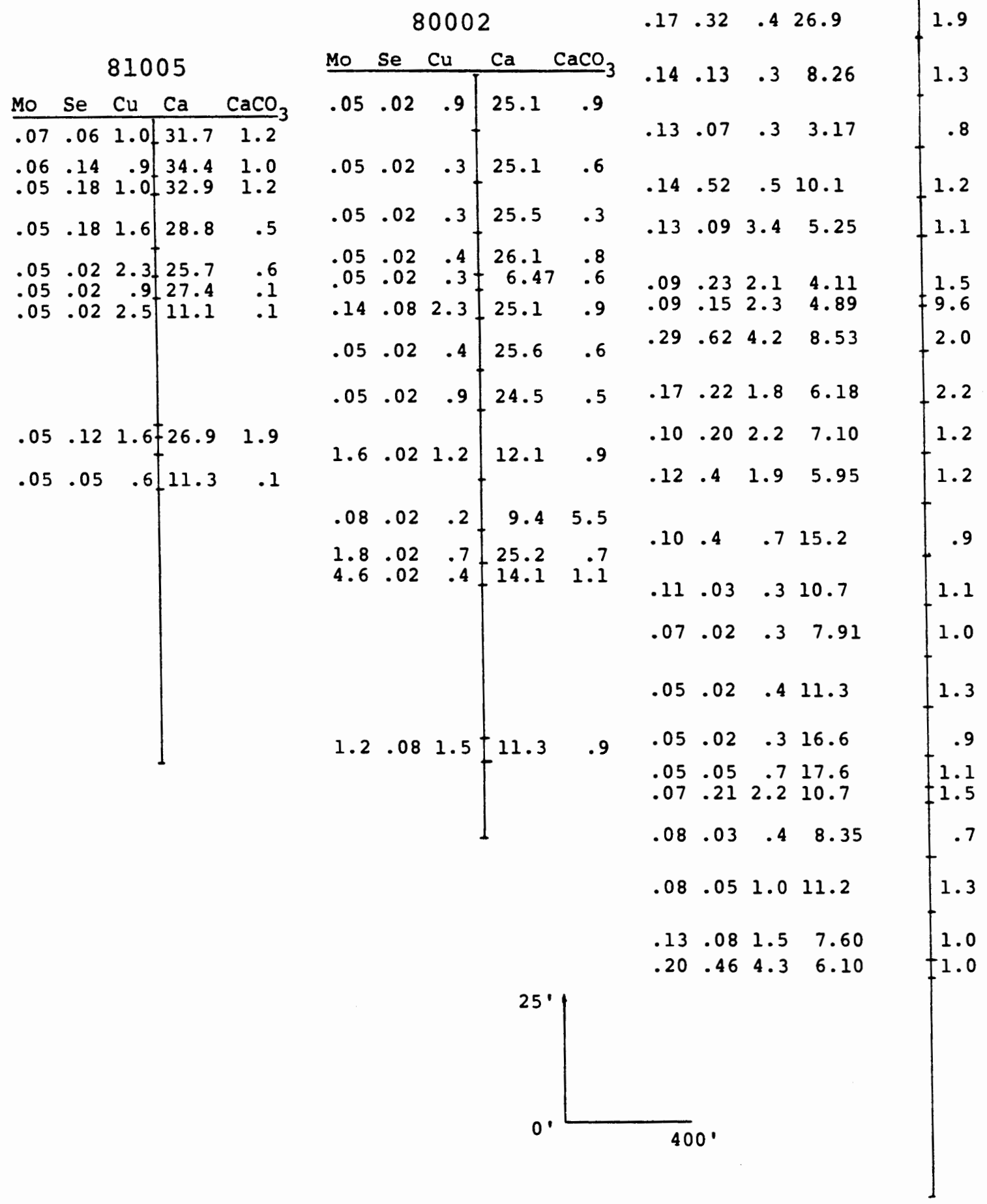

80002

M

81004

Figure 17. Ion distribution for drill holes 81005 , 80002 and 81004 . Refer to Figure 4 for lithologies and Appendix 3 for chemical data. 
overburden sandstones in $80001-O B$ are tan to yellow and are iron stained, while the stratigraphically corresponding sandstones in $81002-O B$ are gray in color (see Figure 3 ). The concentration of copper is lower in the updip samples by a few parts per million. There is also a slight increase in the copper concentration between 80002-OB and 81004-OB, where $81004-O B$ is in the downdip, gray sandstone.

The one substance which shows a definite trend between the yellow and gray sandstones is calcite. The altered sandstones having less $\mathrm{CaCO}_{3}$ (measured on saturated extract) than the unaltered gray sandstones. Those sandstones which are yellow and orange have the lowest values, with the yellowish gray sandstones intermediate between the gray and yellow.

Thus the limonite-stained and enriched sandstones also lack some of the cementing materials of the gray sandstones. The excessive core loss problems at Dave Johnston are in the areas of calcite depletion, the altered, yellow sandstone units. 


\section{CHAPTER 5}

\section{SCANNING ELECTRON MICROSCOPY}

Samples were selected for scanning electron microscopy after $x$-ray analysis showed differences in the clays in the yellow and gray sandstones. The samples were examined with the ISI, model SS 40 microscope in the Physics Department at Portland State University.

Determination of particular clays in the disaggregated samples was not successful. The clays were quite small and difficult to identify and photograph. Several samples could be identified as smectites, and an example is shown in the photo of $80002-O B 10$ in Figure 18. Photos of $80002-O B 10$ show the crinkly, puckering coating of smectite clays on feldspar and quartz grains.

Feldspar grains are subject to leaching and dissolution in acidic environments and may show etching along cleavage traces as a result of low pH environments (Birkland, 1974; Dahl and Hagmaier, 1976). SEM photos of feldspars in the reduced and oxidized zones illustrate the differences in environment between the yellow and gray sandstones. Sample 81004-OB 19 shows a feldspar grain with clean, sharp cleavage traces (see Figure 19). Sample 80001-OB 5, shown in Figure 20, shows a clay coated, etched 


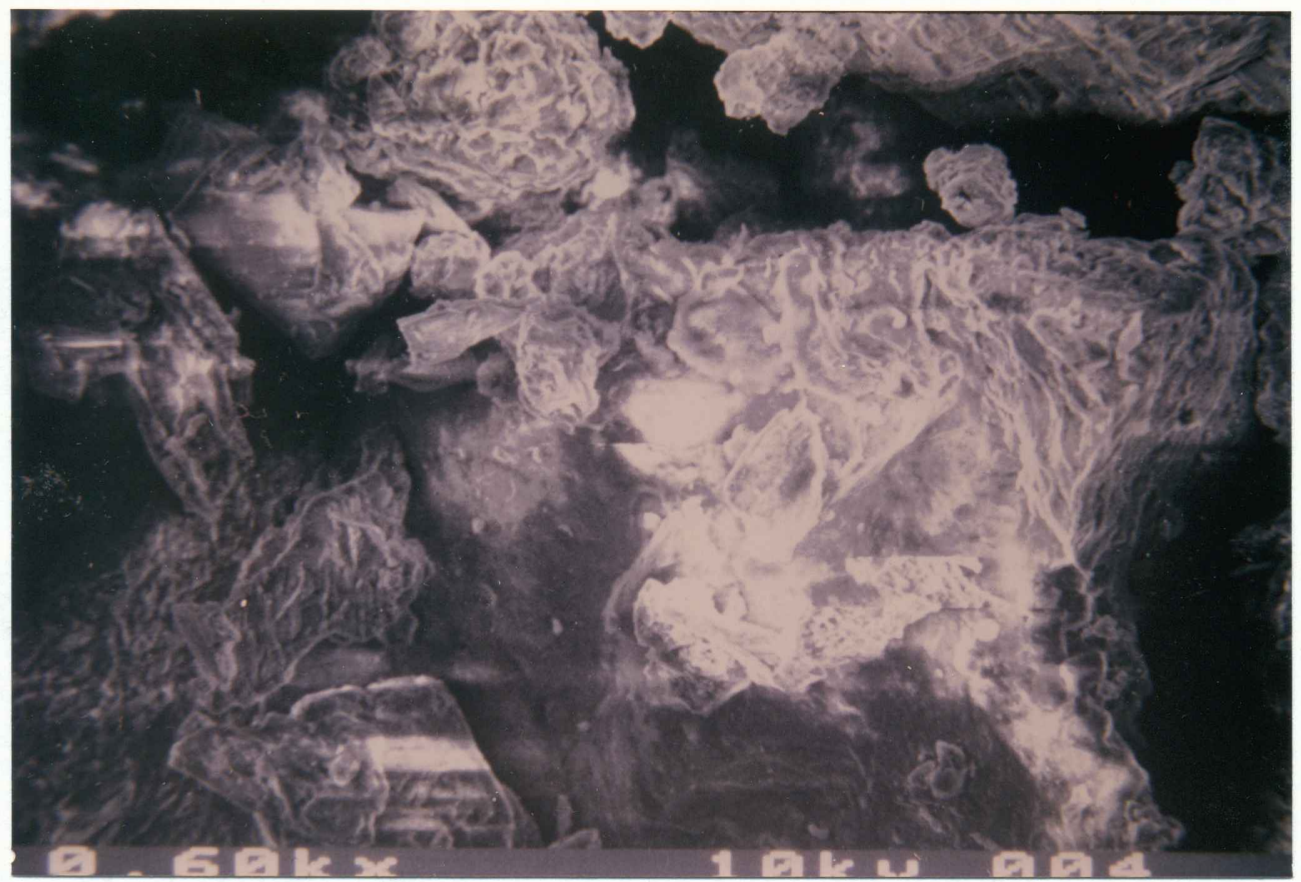

Figure 18. Photomicrograph of smectite clay in sample 80002-OB 10 . 

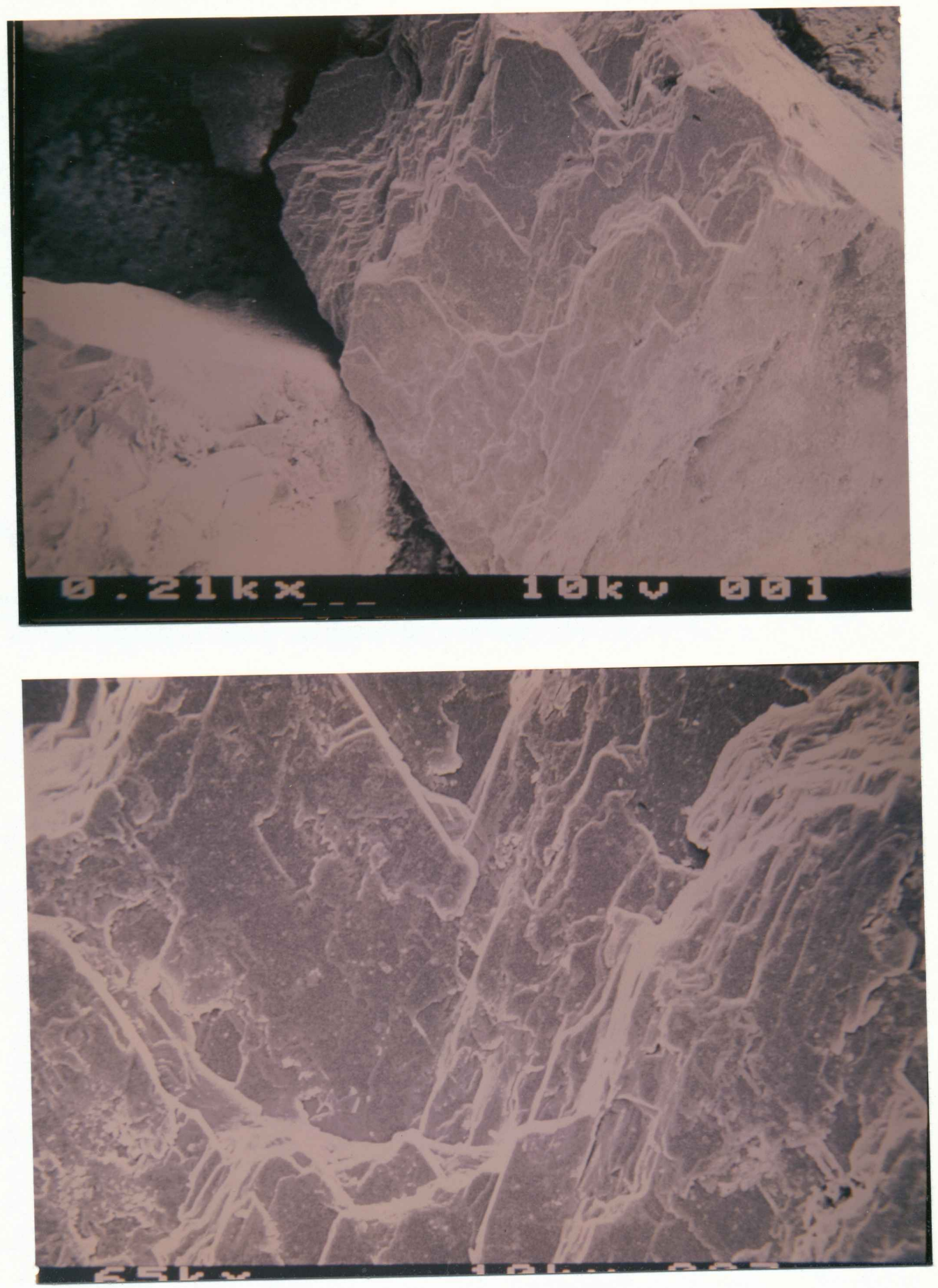

Figure 19. Photomicrograph of a feldspar grain in a normal pH sample (81004-OB 19). 

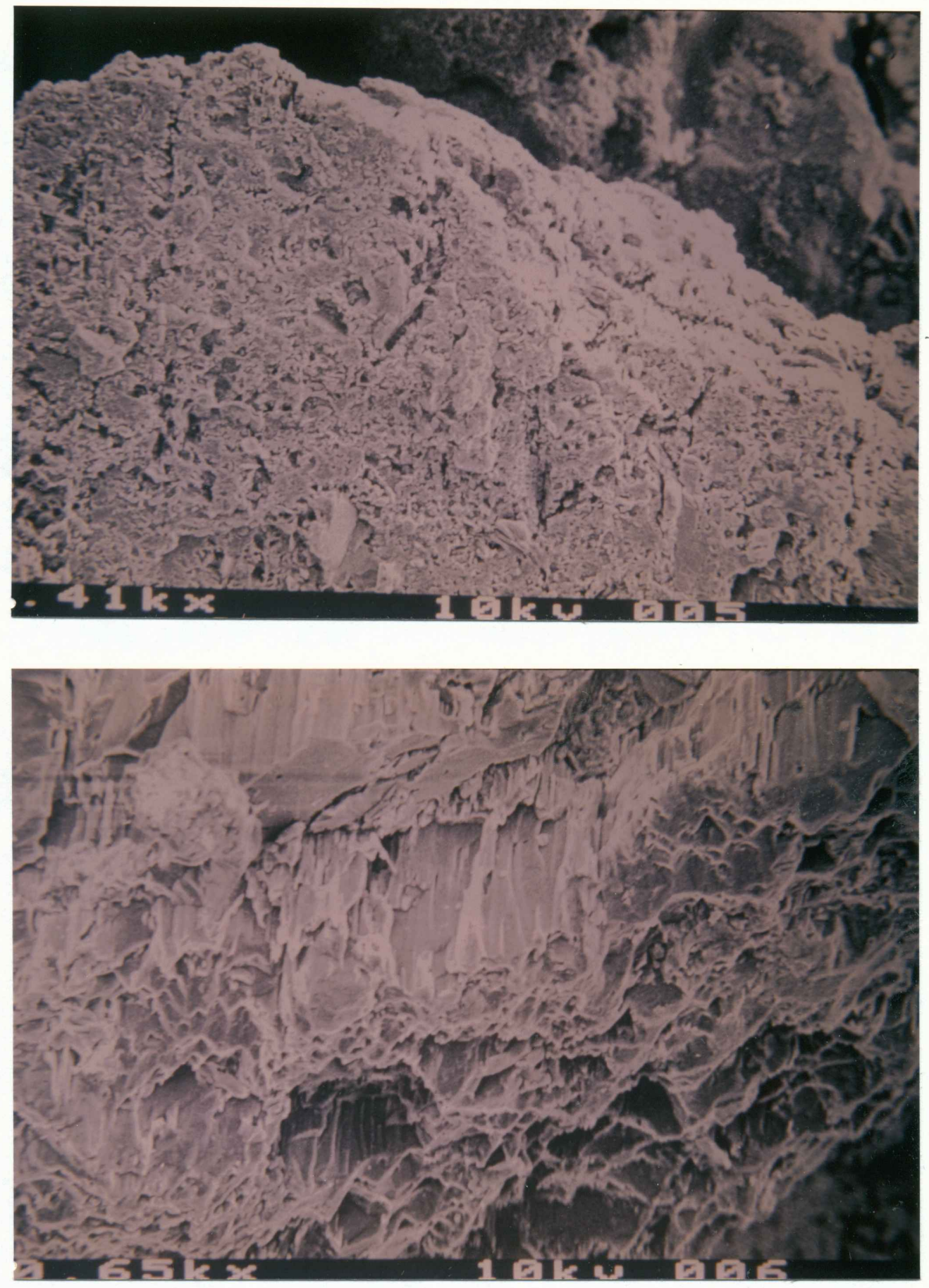

Figure 20. Photomicrograph of an etched feldspar grain in a low pH sample (80001-OB 5). 
feldspar with indistinct cleavage traces, showing signs of dissolution along the cleavage traces. Sample 81004-OB 19 is from a gray sandstone, while $80001-O B 5$ is from a yellow, oxidized zone. 
CHAPTER 6

DISCUSSION AND CONCLUSION

Uranium Roll Front Deposits

Uranium roll front deposits were initially defined by Adler (1964) as having $C$ or $E$ shaped cross sections and forming sinuous lines in map view. Early workers (Adler, 1964; Shawe and Granger, 1965) thought the configuration was the result of precipitation of uranium ore at an interface between solutions of differing compositions and densities. The development of roll front deposits was linked to groundwater movement which caused changes in the $\mathrm{Eh}$ and $\mathrm{pH}$ of the host sandstones by several workers (Adler, 1964 and 1972; Shawe and Granger, 1965; Butler, 1969; Tilsley, 1980). Uranium minerals precipitated as a result of oxidationreduction reactions occurring within the sandstone as the groundwater or mineralizing solution moved through permeable beds (Harshman, 1972).

In the Powder River Basin of Wyoming, uranium roll front deposits have been characterized as a type of supergene enriched (sulfide) deposits by Granger and Warren (1978). The roll fronts of the Powder River Basin typically occur in porous, permeable, gently dipping fluvial or marginal-marine sandstones. They are often closely 
spaced and form multiple, finger-like roll fronts (Davis, 1969). Alteration associated with uranium roll fronts in the basins of Wyoming display distinct boundaries between the altered and unaltered sandstones, with altered sandstone on the concave side of the roll and unaltered host rock on the convex side of the roll front (see Figure 21) (Davis, 1969; Harshman, 1972). The altered sandstone is greenish yellow to orangish red, while the unaltered host sandstone is light to medium gray in color. Davis (1969) and Adler (1972) also identify occasional areas of almost white bleached sandstones occurring adjacent to zones of mineralization. The change in coloration is due to the presence of iron oxides produced by the oxidation of pyrite in the gray sandstones as the mineralizing solutions moved downdip (Adler, 1964 and 1974; Shawe and Granger, 1965; Davis, 1969; Harshman, 1972; Dah1 and Hagmaier, 1976).

Several elements besides uranium and iron are affected by the mineralizing solutions. Selenium, molybdenum, copper and calcite are all precipitated or lost at different areas within the roll front and zone of mineralization (see Figure 21) (Davis, 1969; Adler, 1972; Harshman, 1972; Dahl and Hagmaier, 1976; Granger and Warrent, 1978). According to Davis (1969) a correlation also exists between the position of the roll front and $\mathrm{CO}_{3}=$ and $\mathrm{SO}_{4}=$ concentrations. The reactions involved are well explained in Moran and others, 1978, and in Granger and Warren, 1978. The 


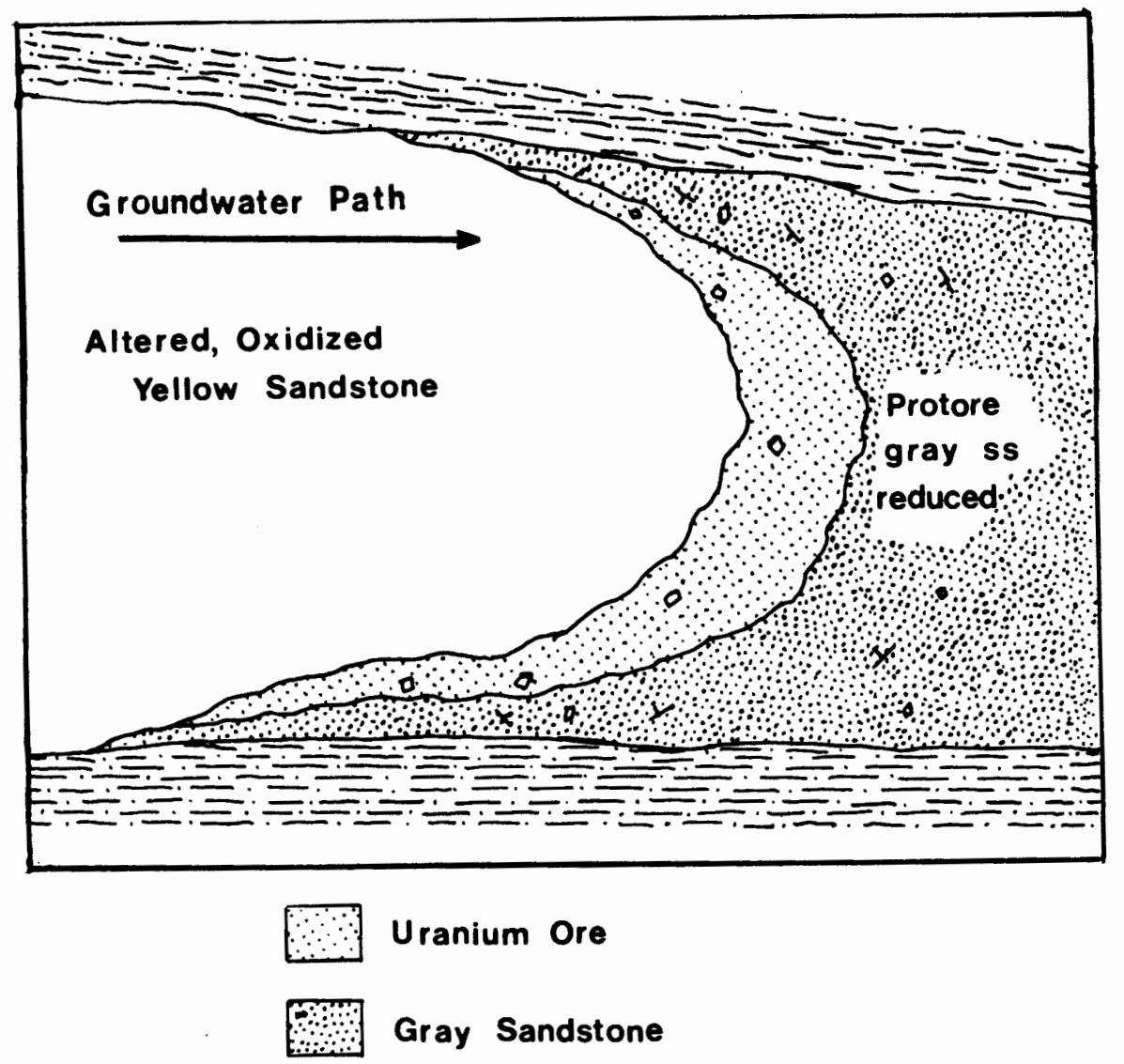

$\square$ Yellow Sandstone

Siltstone, Claystone

It Calcite Cement

Q0 Pyrite

Figure 21. Idealized cross section of roll-type ore body (uranium roll front), no scale (adapted from Dahl and Hagmaier 1976). 
interaction of the carbonate ion, the sulfate ion and even selenium are important as the major constituents in the process of alteration (Hostetter and Garrels, 1962; Harshman, 1972). Along the leading edge of the oxidation tongue, the Eh of the host rock changes abruptly, resulting in the accumulation of various metallic and nonmetallic elements in the mineralizing zone. Uranium, which is soluble to some degree in oxidizing environments (dependent on the interaction of $\mathrm{Eh}$ and $\mathrm{pH})$, precipitates in contact with the reducing environment of the gray, unaltered sandstone (Harshman, 1972). The other elements also precipitate at various areas within the zone (see Figure 22). Most of these precipitates are readily leached in oxidizing environments, and would thus be dissolved again as the mineralizing solution moved further downdip and they were again in an oxidized environment.

Pyrite has been identified as a part of the unaltered sandstone by Shawe and Granger (1965), Davis (1969), Harshman (1972), and Dahl and Hagmaier (1976), and is considered to be epigenetic, but predates ore formation. The pyrite was formed in the reduced environment produced by saturation of the sediments by groundwaters during burial and early diagenesis (Birkland, 1974; Ethridge and others, 1981). Pyrite has also been found immediately adjacent to the roll front (Davis, 1969), in the ore zone. The presence of pyrite at the zone of deposition indicates strongly reducing 


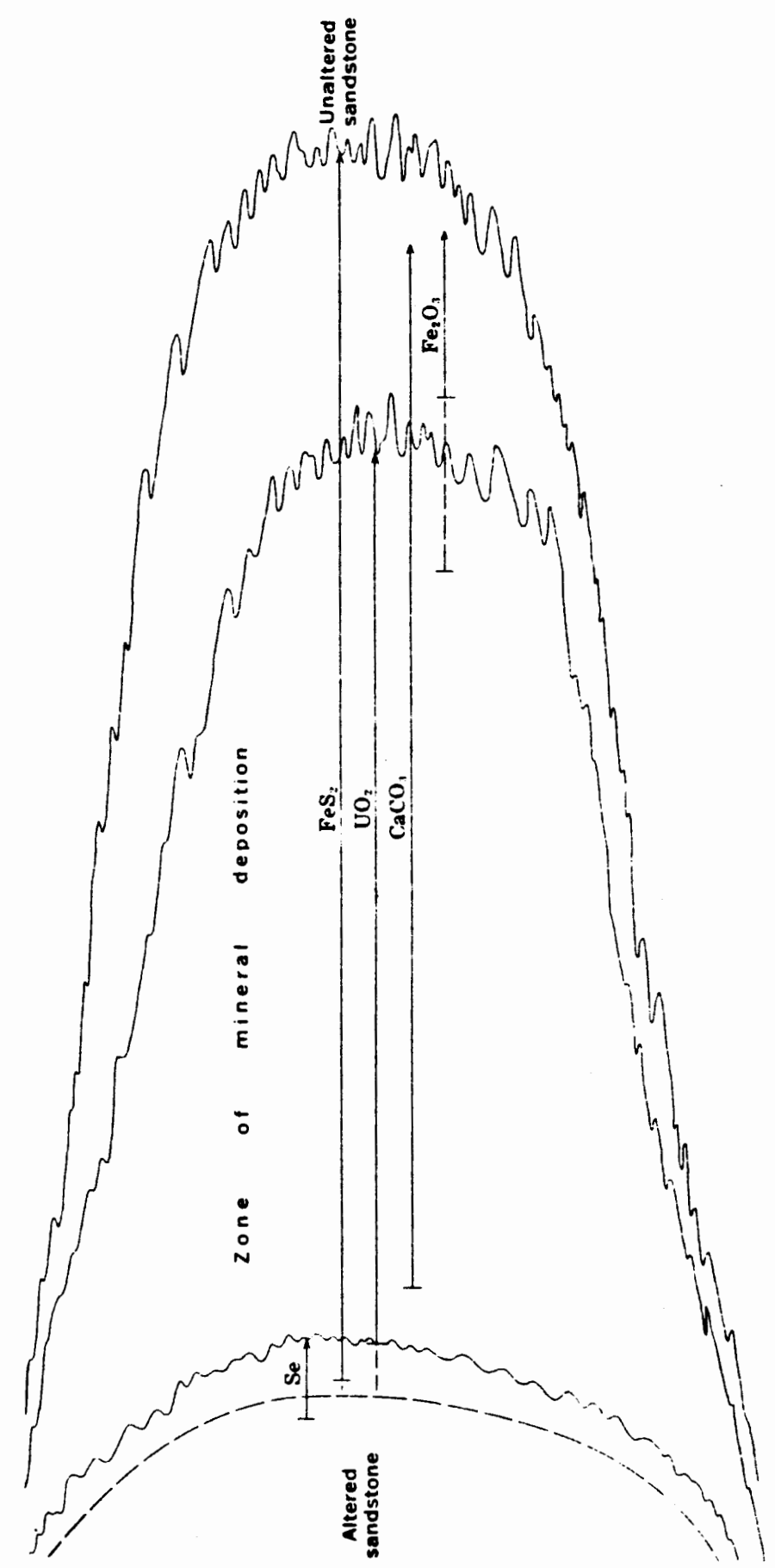

$\dot{\sim}$

o

约

둥

है

$\stackrel{0}{>} \stackrel{0}{\circ}$

坖 동

다 4

c 3

茴

m.

$>0+$

ब1

너

검

त्त 0

थ

प0

म래 30

유

- 1 त。

- $n$ U

ป

(1) ب.

व

ते

(1) 0 少

至

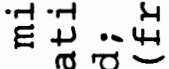

4

0400

> 02

ช 0 亿

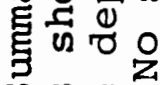

ज) 0

$+11$

- 0

N

ง)

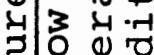

b.

म्नाय है 
conditions in the altered rock of the ore zone (Davis, 1969). According to Davis (1969) and Harshman (1972) these conditions prevail in a zone only a few feet wide, and the occurrence of pyrite in the altered rock is limited to that zone. Behind the ore zone, in the altered sandstone, pyrite is absent or present only in very small scattered amounts. Where pyrite has been found in the altered sandstones, the grain aggregates are corroded and irregular in outline (Harshman, 1972).

The oxidation of the pyrite updip from the roll front produces the characteristic coloring of the altered sandstones (Shawe and Granger, 1965; Davis, 1969; Adler, 1972; Harshman, 1972). Iimonite, including hematite and goethite, are produced and give the yellow to red coloration associated with oxidized and mineralized sandstones (Davis, 1969; Adler, 1972). The oxidation of the pyrite also produces an acidic environment updip from the roll front which is acidic enough to cause the dissolution of magnitite (Adler, 1972).

Limonite is the inclusive term given to the iron oxides of the altered zone, though hematite and goethite are also associated with altered zones. Limonite is used as a field term for iron staining throughout this paper and follows the definition found in Deer and others (1966). Roll front type deposits formed below the surface of the 
water table (Granger and Warren, 1978) and are not well preserved in surface exposures.

\section{CONCLUSION}

Uranium roll front deposits are thus characterized by changes in the host sandstone of color, mineralogy, cement, $\mathrm{pH}$, Eh and ion distribution. The deposits are the result of downdip movement of an oxidizing, slightly alkaline solution which has the capacity to oxidize pyrite and change the Eh of the strata along the leading edge of the solution. Physical and chemical changes in the sedimentary environment result in the precipitation of various metal ions, among them uranium. Oxidation of pyrite in the host sandstone further changes the chemical environment behind the solutior front, reducing the $\mathrm{pH}$ enough to degrade feldspar grains and dissolve calcite cement.

Several features found at the Dave Johnston Coal Field fit the parameters suggested by the mineralizing solutions responsible for the formation of uranium roll front deposits. The changes in color of sandstone units, the problems with core loss, and the acidic overburden values could be explained by changes in environment resulting from roll front mineralization.

Stratigraphic relationships between the Badger and School coal seams, along with petrologic evidence, establishes the continuity of the overburden sandstone units. 
Changes in color and cementation occur within the same unit, and are particularly noticeable in downdip sections.

The oxidation of the pyrite in the gray sandstone produced the limonite found in the yellow sandstone at Dave Johnston. Pyrite is noted in core samples from reduced units, but is not reported in core samples of oxidized sediments. An environment that is oxidizing with respect to pyrite is also oxidizing with respect to chlorite. The absence of chlorite in the yellow sandstone is a result of the destruction of chlorite clays by an oxidizing solution moving through the sandstone.

As a consequence of the oxidation of the pyrite, the pH of the area behind the advancing front was lowered to a slightly acidic condition. The area behind the roll front (or updip) is then more likely to lose calcite through dissolution in the acidic environment. Excessive core loss in overburden cores at Dave Johnston are correlative with areas of oxidized sandstone: the calcite cement has been lost because of the acidic environment produced behind the roll front by the oxidation of pyrite. The destruction of chlorite is also further advanced by the changes in the $\mathrm{pH}$ of the zone behind the roll front since chlorite is vulnerable in acidic environments. Feldspar grains in the altered sandstones also show the affect of the acidic environment by the etching and dissolution of the grains along cleavage boundaries. 
The $x$-ray analyses of the overburden drill cores at Dave Johnston corroborates this interpretation. Chlorite is restricted to the reduced environment of the gray sandstone and is absent from those sandstones which show the characteristics of an oxidized zone. The sandstones in the oxidized zones lack clays which are associated with alkaline environments, and reflect a change in ion substitution in the interlayer sites in the montmorillonite clays. Dissolution of the calcite freed calcium ions for substitution, replacing the sodium already present in those sites.

Changes in calcite concentration are also reflected in the chemical analyses of the overburden, which show less calcite in the altered sandstones. Copper also shows a slight decrease in the altered sandstone, though none of the values show the degree of change in concentration that Harshman reports in the uranium deposits of the Petrotomics Company Section 9 pit. Harshman's study was located in the Shirley Basin of Wyoming (see Figure 1), where he found as much as $20 \mathrm{ppm}$ copper in the unaltered sandstones compared to 2-4 ppm in the altered sandstone (Harshman, 1972).

Alternative explanations for the changes in the chemical and physical characteristics of the overburden sandstone include facies changes and cut and fill through the sandstone unit. Stratigraphic and petrologic constraints preclude the acceptance of either of these hypotheses. The gray sandstone is stratigraphically 
equivalent to the yellow sandstone, and is found in this position both downdip to the east and to the north. An erosional channel would continue northward, following the drainage patterns of the Eocene Wasatch, or would turn eastward toward the synclinal axis. Drill hole data does not show a continuation of the yellow sandstone eastward, or to the north. Rather, the yellow sandstone ends abruptly in both directions. A facies change does not offer a reasonable solution for the changes observed in the clay mineralogy while the sand size minerals remain essentially the same in both the gray and yellow units. A facies change should also produce greater changes in the particle size than is reflected in the two sandstone units, and should not appear as a continuous unit throughout the mine area. Uranium roll front wodels require a solution with the same characteristics as the one proposed for the overburden sandstone at the Dave Johnston Coal Field. A roll front solution fits the parameters indicated by this study and probably is responsible for the alteration at the Dave Johnston Coal Field.

The physical and chemical changes in portions of the overburden sandstones at the Dave Johnston Coal Field appear to be the direct result of a solution moving in a downdip direction. The parameters established by the results of this study require that the solution be oxidizing with respect to pyrite and have an Eh potential capable of 
leaching copper. The oxidation of pyrite would, in turn, produce an environment acidic enough to dissolve calcite, destroy chlorite and etch feldspar grains, as well as giving an iron oxide stain to the altered sandstone.

The failure of this study to find any close correlation between metal ion distribution and the altered and unaltered zones may be attributable to the scale on which the analysis was done. The studies which have shown the correlations have been conducted in uranium pits, across the roll fronts themselves, with samples taken at one or five foot intervals. The drill cores used in this study are all several hundred feet apart and do not offer an opportunity to study ion distribution across a localized area of mineralization.

In a study of the Highland uranium deposits, Dahl and Hagmaier (1976) were unable to find any particular relationship between the uranium mineralization and metal concentrations. This study is of particular interest since the Highland deposits are in sandstone which underlie a large portion of the Powder River Basin and are approximately 600 feet below the Badger coal seam. Specifically, the information used by Dahl and Hagmaier came from drill holes and mines 1 to 18 miles east of the Dave Johnston Coal Field. Again their data was primarily from drill cores spaced several hundred feet apart. 
If a detailed, closely spaced program were initiated within the Dave Johnston mine, in a downdip direction, it might be possible to demonstrate some of the correlations between roll front mineralization that others have found. 


\section{CHAPTER 7}

POTENTIAL PROBLEMS FOR RECLAMATION

The acidic values measured for portions of the overburden at the Dave Johnston mine pose several questions regarding the removal and eventual reclamation of the mine area. The potential negative effect on re-establishing ground cover due to acidic soils and the possibility of groundwater contamination by acidic waters and ion movement in groundwater are major ecological concerns.

The ability of metal ions and the sulfate ion to migrate in the water in spoils could have an impact on groundwater systems adjacent to mined areas. The water moving into and through a mined area, both vertically and horizontally, could become enriched in undesirable cations such as $\mathrm{Ca}^{++}$and $\mathrm{Na}^{+}$, and $\mathrm{SO}_{4}^{=}$and $\mathrm{HCO}_{3}^{-}$anions.

The potential effects on the groundwater and on reclamation depend in large part on the hydrology of the mined area and its surroundings. Before effective reclamation can be done, it is necessary to know the groundwatersurface water interactions of the area, the rechargedischarge relations, and the water table configuration and potentiometric head (see Groenewold and others, 1981). The rate of groundwater movement can greatly affect the salinity 
and sodium ion concentration in sediments. Repeated leaching and flushing can keep these levels low. Lateral movement of water into a mined area, or upward from below the spoils, can bring dissolved constituents into the mined area. If this water evaporates, those constituents are precipitated and can result in the accumulation of $\mathrm{Na}^{+}$and the build up of salinity. Low precipitation, or nonmovement of groundwater causes the weathering of spoils in place, with the products remaining in situ (Moran, Groenewold and Cherry, 1978).

The availability of ions depends upon the mineralogy and oxidation state of the spoils material. Mineralogy of the sediments in the Powder River Basin is tied to provenance and the original depositional environment of the lithologies (Sandoval, 1973; Groenewold and others, 1981). In particular, the mineralogy at the Dave Johnston Coal Field has been affected by post-depositional mineralizing solutions. Studies by the North Dakota Geological Survey have shown pyrite, gypsum, calcite, dolomite and clay minerals to be the most important minerals affecting groundwater chemistry, especially in the unsaturated zone between the surface and the water table (Groenewold and others, 1981).

oxidation of pyrite and the decay of organic matter, which produces $\mathrm{CO}_{2}$, are two reactions that produce an acidic environment unless they are buffered by the dissolu- 
tion of carbonate minerals. These reactions will take place in the near surface zones of the strata, where oxygen is available from the atmosphere and rainwater. Salt accumulation also occurs in this zone because of the alternating wet and dry conditions (see Groenewold and others, 1981). These reactions are part of the natural cycle and are a given in the Powder River Basin. If there is a concentration of detrimental ions near the surface, these reactions could result in toxic or hazardous build ups of $\mathrm{Na}^{+}, \mathrm{SO}_{4}{ }^{\prime}$ $\mathrm{Ca}^{++}$, and/or $\mathrm{HCO}_{3}^{-}$, particularly if oxygen has been incorporated into the strata during excavation and reclamation. oxygen in the trapped air in the spoils would be consumed in the oxidation of pyrite if pyrite was present in the spoils (Groenewold and others, 1981), thus contributing to potential build ups of $\mathrm{SO}_{4}^{=}$and $\mathrm{Na}^{+}$.

If the spoils in a near surface position are lacking in, or are low in pyrite, other minerals need to be evaluated in terms of detrimental weathering products. oxidized units may lack pyrite, but they may have secondary accumulations of gypsum or sulfate from the previous oxidation of pyrite. The presence of sulfate would then depend upon whether or not the salts have been flushed out of the strata (Moran and others, 1978).

At Dave Johnston reclamation of spoils could pose problems, both in terms of the oxidized and the reduced sandstones. Research by the North Dakota Survey has shown 
that detrimental chemical reactions can be minimized by selective handling and placement of overburden materials, as well as control of the degradation of the groundwater. Specifically, unweathered pyritic sediments should be restricted from the chemically active near-surface zone (Moran and others, 1978; Groenewold and others, 1981). The problems of accumulations of sulfate and sodium ions can be addressed by selective placement of the oxidized and reduced units at Dave Johnston.

The yellow oxidized sandstones could be utilized as outlined by Moran and others (1978) whereby the production of sulfate from pyrite oxidation is greatly reduced by the placement of permeable sand beneath the soil veneer, particularly if most, or all, of the pyrite has been previously oxidized. A permeable sand in the subsoil zone would quicken infiltration and help prevent the formation and accumulation of detrimental minerals.

By restricting the unweathered pyritic sandstones to lower positions in the spoils, and placing the oxidized poorly indurated yellow sandstones directly beneath the reclaimed soil, the resultant porewater should be lower in dissolved solids. In other words, the reduced gray sandstones quite possibly hold a greater potential for groundwater contamination and salt build up than do the oxidized yellow sandstones. There is a greater amount of pyrite and calcite in the gray sandstones, two of the key factors in 
the chemical reactions leading to groundwater contamination. The oxidized sandstones have far fewer soluble ions available for leaching by groundwater.

The sodium content of the montmorillonite clays and the entire overburden must be examined to judge the potential amount of $\mathrm{Na}^{+}$available in the spoils. The dissolution of calcite frees $\mathrm{Ca}^{++}$for exchange with the $\mathrm{Na}^{+}$in the montmorillonite, causing an increase in the amount of free $\mathrm{Na}^{+}$. The $x$-ray analysis shows an increase in $\mathrm{Ca}^{++}$substitution in the oxidized sandstones. The sodium rich montmorillonites of the gray sandstones become calcium rich as a result of the dissolution of calcite, freeing sodium ions for possible salt formation. The pertinent question is how much sodium is left in the oxidized sandstone? If the oxidized sandstone is placed in a near surface environment, the $\mathrm{Na}^{+}$may be mobilized in the groundwater if they are still present in the oxidized sandstone. 


\section{REFERENCES}

Adler, н.н., 1964, The conceptual uranium ore roll and its significance in uranium exploration: Economic Geology, v. 59, p. 46-53.

--- 1972, Explorations for uranium in sandstones: International Atomic Energy Agency, Vienna, 1972, Uranium Exploration Methods, Proceedings, p. 155-169.

Birkland, P.W., 1974, Pedology, weathering, and geomorphological research: New York, Oxford University Press, Inc., $285 \mathrm{p}$.

Brown, George, 1961, The x-ray identification and crystal structures of clay minerals: London, Jarrold and Sons, Ltd., 544 p.

Butler, A.P., Jr., 1969, Groundwater as related to the origin and search for uranium deposits in sandstone: Contributions to Geology, Laramie, Wyoming, v. 8 , no. 2 , pt. 1 , p. 81-86.

Carroll, Dorothy, 1970, Clay minerals: a guide to their $x$-ray identification: Geol. Soc. Am. Special Paper $126,80 \mathrm{p}$.

Dahl, A.R., and Hagmaier, J.L., 1976, Genesis and characteristics of the southern Powder River Basin uranium deposits, Wyoming: Wyoming Geol. Assoc. Guidebook No. 28 , p. 243-252.

Davis, J.F., 1969, Uranium deposits of the Powder River Basin: Contributions to Geology, Laramie, Wyoming, v. 8, no. 2, pt. 1, p. 131-141.

Deer, W.A., Howie, R.A., and zussman, J., 1966, An introduction to the rock forming minerals (11th ed.): Bungay, Sulfolk, Richard clay (The Chaucer Press) Ltd. , $528 \mathrm{p}$.

Denson, N.M., Dover, J.H., and Osmonson, L.M., 1980, Lower Tertiary coal bed distribution and coal resources of the Reno Juntion-Antelope Creek area, Campbell, Converse, Niobrara, and Weston Counties, Wyoming: U.S.G.S. Miscellaneous Investigations Series, scale 1:125,000, Map I-1201. 
Ethridge, F.G., Jackson, T.J., and Youngberg, A.D., 1981, Floodbasin sequence of a fine-grained meander belt subsystem: the coal-bearing Lower Wasatch and Upper Fort Union Formations, southern Powder River Basin, Wyoming: SEPM Special Publication No. 31, p. 191-209.

Flores, R.M., 1981, Coal deposition in fluvial paleoenvironments of the Paleocene Tongue River Member of the Fort Union Formation, Powder River area, Powder River Basin, Wyoming and Montana: SEPM Special Publication No. 31, p. 169-190.

Flores, R.M., and Ethridge, F.G., 1981, Nonmarine deposits and the search for energy resources and minerals: SEPM Special Publication No. 31, p. 1-17.

Glass, G.B., 1981, Coal resources of the Powder River coal basin: The Geological Survey of Wyoming Public Information Circular No. 14, p. 97-131.

Granger, H.C., and Warren, C.G., 1978, Some speculations on the genetic geochemistry and hydrology of rolltype uranium deposits: Wyoming Geol. Assoc. Guidebook, No. 30 , p. 349-361.

Grim, Ralph Early, 1962, Applied Clay Mineralogy: New York, McGray Hill, 422 p.

Groenewold, G.H, Rehm, B.W., and Cherry, J.A., 1981, Depositional setting and groundwater quality in coal-bearing sediments and spoils in western North Dakota: SEPM Special Publication No. 31, p. 157-167.

Harshman, E.N., 1972, Geology and uranium deposits, Shirley Basin area, Wyoming: U.S. Geological Survey Professional Paper $745,77 \mathrm{p}$.

Hostetler, P.B., and Garrels, R.M., 1962, Transportation and precipitation of uranium and vanadium at low temperatures, with special reference to sandstonetype uranium deposits: Economic Geology, v. 57, p. 137-167.

Millot, Georges, 1970, Geology of Clays: Belgium, Masson et $\mathrm{c}^{1 \mathrm{e}}, 429 \mathrm{p}$.

Moran, S.R., Groenewold, G.H., and Cherry, J.A., 1978, Geologic, hydrologic and geochemical concepts and techniques in overburden characterization for minedland reclamation: North Dakota Geol. Survey Report of Investigations No. 63, $152 \mathrm{p}$. 
Project Report, 1980, Dave Johnston Mine, Base Document: Volume 11, Appendix D-7, $53 \mathrm{p}$.

Sandoval, F.M, Bond, J.J., Power, J.F., Willis, W.O., 1973, Lignite mine spoils in the northern Great Plains-Characteristics and potential for reclamation: North Dakota Geol. Survey Educational Series 5 , p. 1-24.

Shawe, D.R., and Granger, H.C., 1965, Uranium ore rollsand analysis: Economic Geology, v. 60, p. 240-250.

Thorez, J., 1976, Practical identification of clay minerals: Dison, Belgium, Editions G. Lelotte, $90 \mathrm{p}$.

Tilsley, J.E., 1980, Review of major and minor uranium deposits and occurrences and their classification schemes: Geosciences Canada, v. 7, no. 4, p. 143-148.

Triplehorn, D.M., 1970, Clay mineral diagenesis in Atoka (Pennsylvanian) sandstones, Crawford County, Arkansas: Jour. of Sed. Pet., v. 40 , no. 3, p. 838847 .

Wilson, M.D., and Pittman, E.D., 1977, Authogenic clays in sandstones: recognition and influence on resevoir properties and paleoenvironmental analysis: Journ. of Sed. Pet., v. 47, no. 1, p. 3-31.

Wyoming Department of Environmental Quality, 1981, Guideline No. 1: Land Quality Division. 
APPENDIX 1

METHODS OF SAMPLE TREATMENT 


\section{Overburden Sampling*}

a. Sample holes should be located so as to adequately represent the quality of the querburden and interburden. The following sampling procedures are recommended.

(1) Sampling intensity should be at a minimum of one sample hole per 160 acres (four per section). Holes should be relatively evenly spaced and at least two holes per section should be cored. This spacing may need to be adjusted due to the nature of the geology of the area. Sample holes should extend to below the mineral to be mined, with samples taken so as to represent all strata.

(2) If the proposed pit size is to be less than 160 acres, then at least two holes should be taken. At least one of these holes should be cored.

(3) For areas with dipping mineral seams, the holes should generally be located on the low side of the dip to insure that all overburden is sampled. Holes should be parallel to the strike at a 1000 foot spacing.

(4) Detailed geologist logs should be provided for each sample hole.

b. All lithotypes and unconsolidated units of the overburden and interburden should be sampled and evaluated by laboratory analyses. Recommended procedures for sampling are:

(1) drilling methods which will prevent contamination of samples should be used (Power and Sandoval, 1976):

(2) samples should be taken such that total thickness of the sampled strata is not greater than ten feet. Those strata that may have adverse characteristics (i.e.. pyrites) should be specifically sampled;

(3) where lithotypes have a thickness greater than ten feet, samples should be taken at ten foot intervals and composited for analysis. In no instance should a composited sample represent more than a thirty foot thickness;

*Taken from the Wyoming D.E.Q. Guideline No. 1. 
(4) each stratum sampled should be designated by thickness, depth, and hole number;

(5) coal that is to be spoiled (rider seams, thin stringers, etc.) should be sampled as overburden:

(6) polyethylene plastic bags should be used for sample collection anç shipping. Moist or wet samples should be immediately frozen or spread to dry on a waterproof material, and stored in closed water resistant containers until analyzed (Sandoval and power, 1978). Chemically unstable constitutents; i.e., nitrate-nitrogen, will require special precautions to obtain accurate analysis. All samples should be ground to pass through a $2 \mathrm{~mm}$ ( 10 mesh) sieve.

4. Laboratory Analysis

a. Table I-l (Appendix I) lists the parameters of greatest concern for establishing overburden and interburden quality and the recommended methods of analysis. Other methods may be used if they provide comparable results. Any change in the recommended procedures should be cleared with the Land Quality Division.

b. Analysis of parameters in addition to those listed in Table I-I may be required based upon the geologic nature of a mining area. It is recommended that Land Quality personnel be consulted prior to doing any analytical work. 


\section{Appendix I}

Parameters, Analytical Procedures and Suitability Criteria for Topsoil and Overburden Analyses and Evaluation.

Table I-1: Recomnended procedures for analyzing soils and cisrburien/ interburden quality for coal and uranium mires.

\begin{tabular}{|c|c|c|c|}
\hline $\begin{array}{l}\text { Parán } \\
\text { Topsoil } \\
\end{array}$ & $\begin{array}{l}\text { tex } \\
\text { Overburden/ } \\
\text { Interburden }\end{array}$ & Reported As & Recortenced Froce Ëre \\
\hline 1. $\mathrm{pH}$ & $\mathrm{pH}$ & $\begin{array}{l}\text { Hyorogen ion activity at } \\
\text { saturation (Faste) }\end{array}$ & $\begin{array}{l}\text { LSDA l:ancbook } 60 \text {, } \\
\text { ettod }(21 \mathrm{a}), \text { PG. }: 02\end{array}$ \\
\hline $\begin{array}{l}\text { 2. Condurti- } \\
\text { vity }\end{array}$ & Coniuctivity & rinos/cm e $25^{\circ} \mathrm{C}$ & 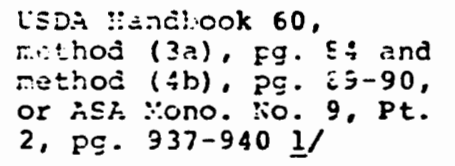 \\
\hline $\begin{array}{c}\text { 3. Satura- } \\
\text { tion }\end{array}$ & Saturation & Percent & 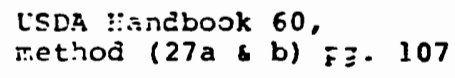 \\
\hline $\begin{array}{l}\text { 4.Particle- } \\
\text { size } \\
\text { Analysis }\end{array}$ & & $\begin{array}{l}\text { clay, silt, sand, and } \\
\text { very fine sand ( } \mathrm{ffs}=0.05 \\
-0.1 \mathrm{~mm})\end{array}$ & 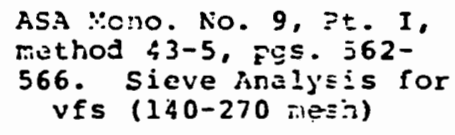 \\
\hline 5. & $\begin{array}{l}\text { Particle size } \\
\text { Analysis }\end{array}$ & olay, silt, and sand & 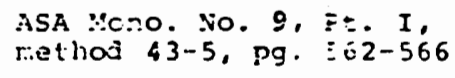 \\
\hline 6. Mexture & Texture & USDA textural class & 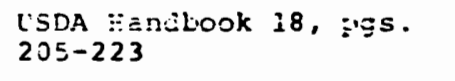 \\
\hline $\begin{array}{l}\text { 7. Soluble } \\
\text { Ca, :ig, } \\
\text { anc :ia }\end{array}$ & $\begin{array}{l}\text { Soluble Ca, } \\
\because g, \text { i: Na }\end{array}$ & $\operatorname{meg} / 1$ & 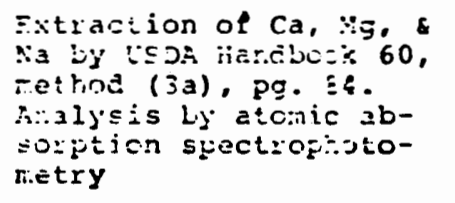 \\
\hline $\begin{array}{l}\text { 8. Sodilim- } \\
\text { rasorp- } \\
\text { tion } \\
\text { ratio }\end{array}$ & $\begin{array}{l}\text { soivium- } \\
\text { isorption } \\
\text { ratio }\end{array}$ & $\begin{array}{l}\text { SAR calculated irom } \\
\text { soluble Ca, lig, \& Na } \\
\text { concentrations }\end{array}$ & 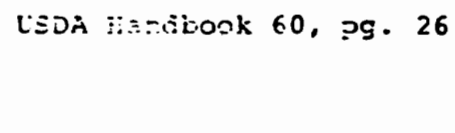 \\
\hline
\end{tabular}


9.Carbo-

nates $\underline{2}$

10.Selenium selenium

11.Boron 4/ Boron ppm

12.

13. Organic Matter

14.

15.

16.

17.

Molybdenum
Percent

ppm to a lower detection limit of 0.02

Nitrate- ppm

Percent

ppm to a lower detection limit of 0.1

ppm

Acid potential in meg $\mathrm{H}^{+} / 100 \mathrm{gr}$. neutralization potential in tons $\mathrm{CaCO}_{3}$ equiv. 1000 tons acid-base potential + tons $\mathrm{CaCO}_{3}$ equiv. 1000 tons

ppm
USDA Handbook 60 , method (23b), pg. 105

Extraction by ASA Mono. No. 9, pt. 2, method 80-3, pg. 1122; Analysis by the DAN-Flourometric method (Levesque Vendett, 1971) or the Gaseous Hydride Method (US EPA 1979) a atomic absorption spectrophotometry

Extraction by ASA Mono No. 9, Pt. 2, method 75-4, pg. 1062. Analys is by the curcumin method (Standard Methods, 1976)

Extraction by ASA Mono No. 9, Pt. 2, method 84-5. 3.3, pg. 1216

ASA Mono. No. 9 Pt. 2 , method 90-3, pg. 13721376

$\left(\mathrm{NH}_{4}\right)_{2} \mathrm{CO}_{3}$ extractable (vlek, 1975). Acceptable procedure available from. LQD

DTPA Extraction (Follett - Lindsay, 1971). Analysis by atomic absorption spectrophotontetry

Smith R.M. et al. (1974) pg. 48-51

DTPA Extraction (Follett c Lindsay, 1971). Analysis by atomic absorption spectrophotometry 
18. Arsenic I/ F.pm

FH·6.5 :ixed agid ixtractable hs $10.04 \mathrm{~N}$ HCl c $0.025 \mathrm{~N} \mathrm{H}_{2} \mathrm{SO}_{4}$ ), nie I $\equiv$ on et a . 1953\}. pH>6.5 Eicarborate-Extractable is $\left(0.4 \mathrm{~N}: \mathrm{aHCO}_{3}\right)(015 \mathrm{en}$ et a). 1954)

19. Coarse

Percent

LSDA Hanubook 436, ipp.

Fragment

I. Pg. 472: Soil S:-zvey

Laboratory Methods

Procedures for Col:ect-

ing soil sumples, Egs.

9 and $12-13$

1/ Conactivity should be ceternined immediately after the extract is ci:ained.

2/ Analysis recommended where calcic horizon is suspected. 3/ Analysis for selenium reconmended. on soils where primary selenium inc:-
cator ilants are present (Rosenfeld and Bcath, 1964).

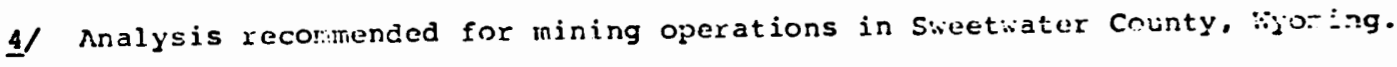

5/ Referred to as acid-neutralization iccount by $s_{\pi i t h}$ et al. (1974).

6/ Analysis recommended for coal mine operations in sheridan and cas:bell countics, hyoming.

If Analysis recommended for uranium operations. 
APPENDIX 2

X-RAY DATA 


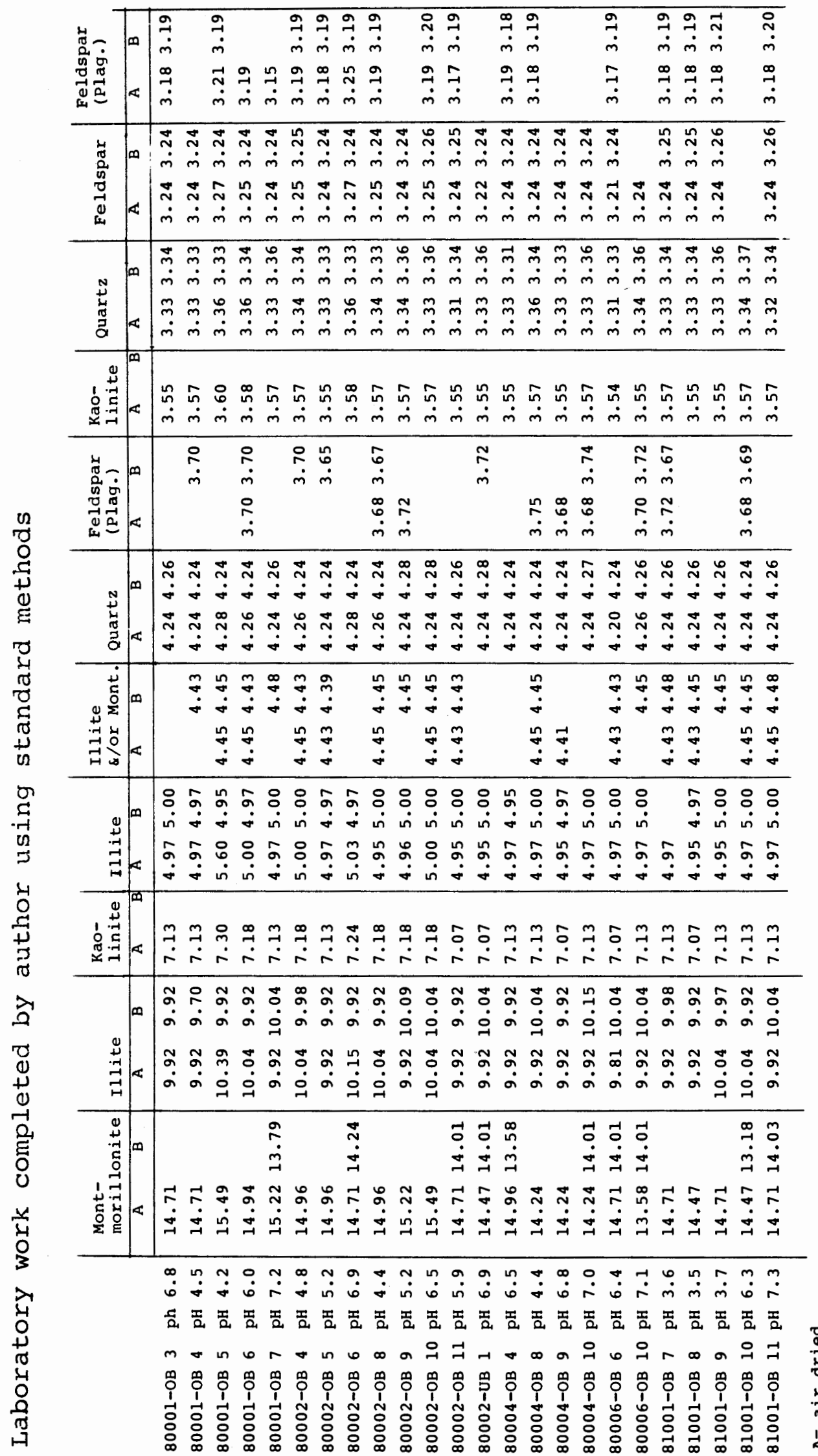




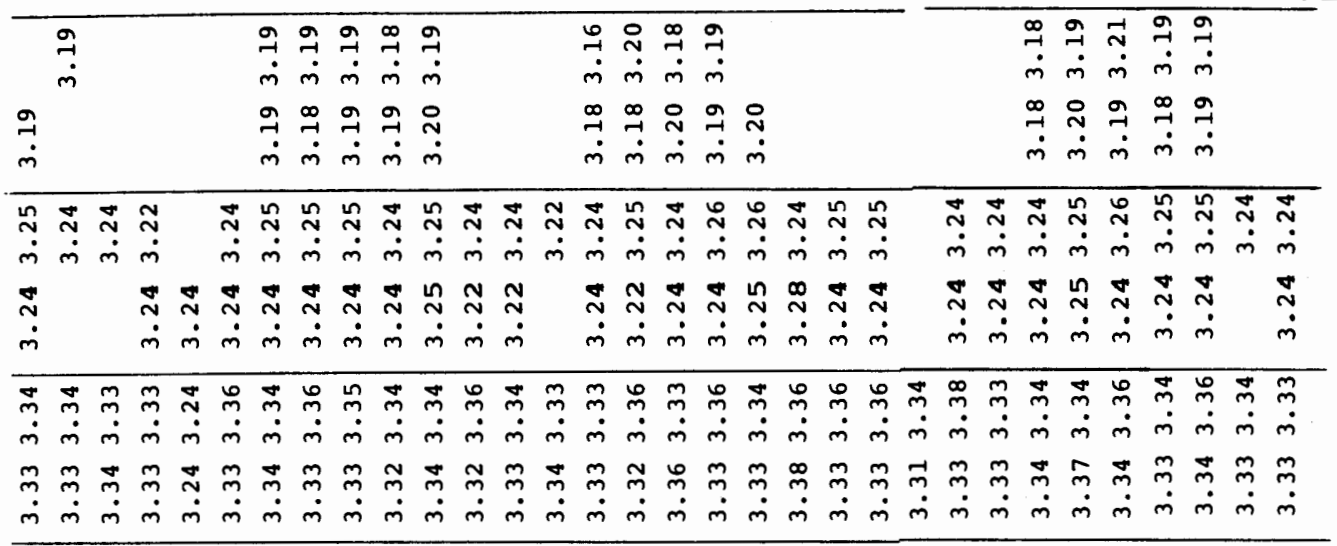

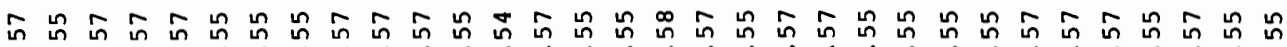
$\dot{m} \dot{m} \dot{m} \dot{m} \dot{m} \dot{m} \dot{m} \dot{m} \dot{m} \dot{m} \dot{m} \dot{m} \dot{m} \dot{m} \dot{m} \dot{m} \dot{m} \dot{m} \dot{m} \dot{m} \dot{m} \dot{m} \dot{m} \dot{m} \dot{m} \dot{m} \dot{m}$

\begin{tabular}{|c|c|c|c|c|c|}
\hline 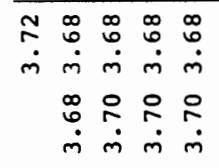 & 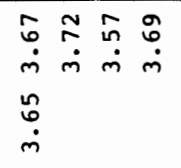 & \begin{tabular}{ll}
\multirow{2}{*}{} & $\infty$ \\
$\dot{m}$ & 0 \\
$\dot{m}$ & $\dot{m}$ \\
0 & \\
$\dot{m}$ &
\end{tabular} & 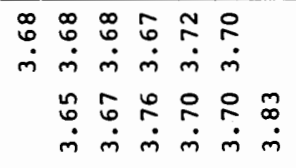 & 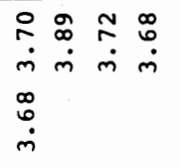 & 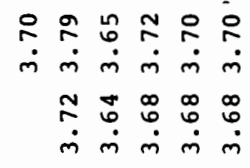 \\
\hline
\end{tabular}

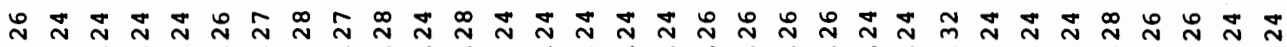

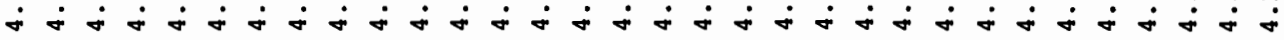

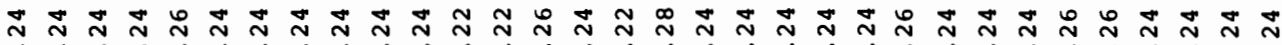

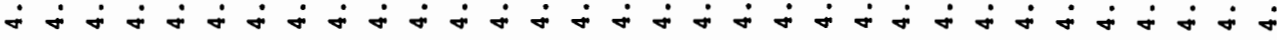

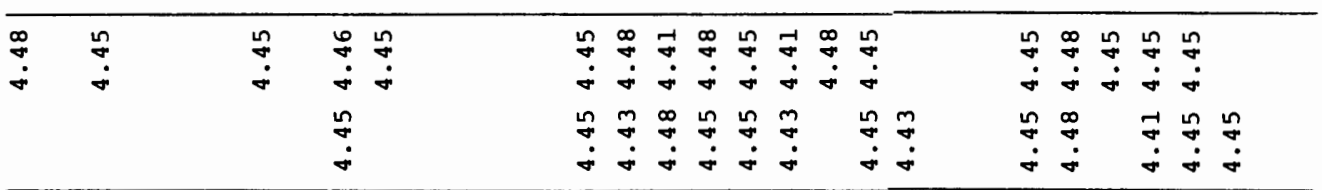

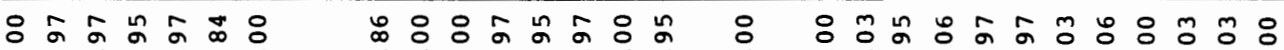

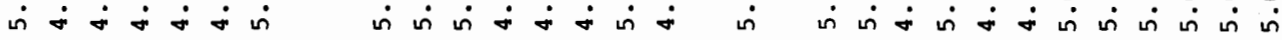

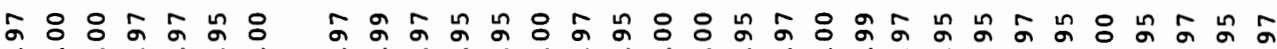

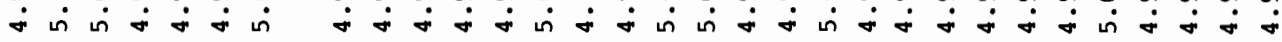

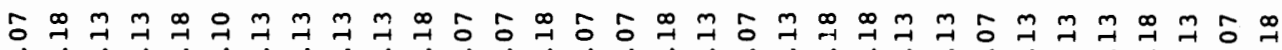

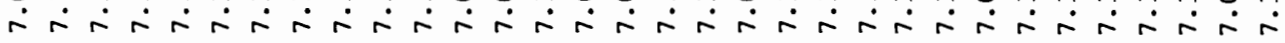

สิ สี ส ส

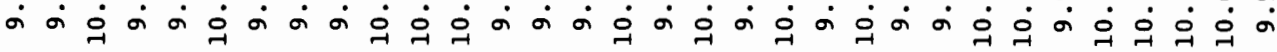

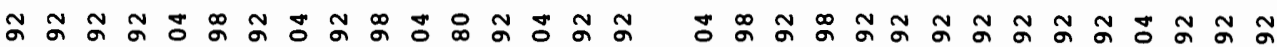

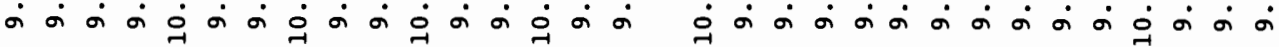

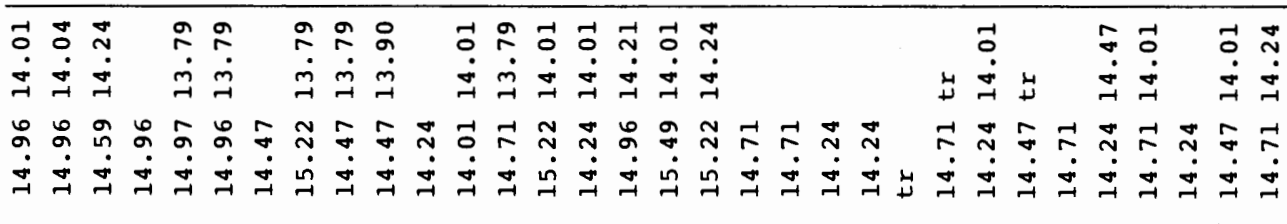

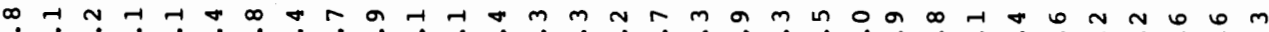

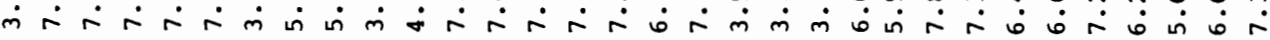

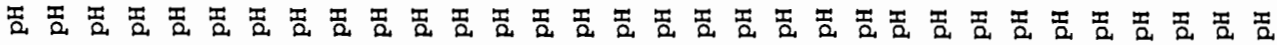

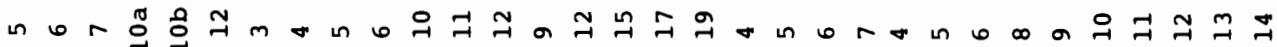

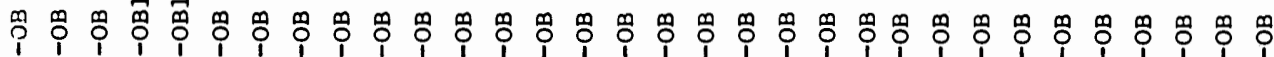

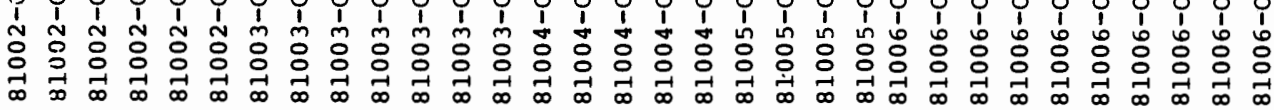




\begin{tabular}{|c|c|c|c|c|c|c|c|c|}
\hline Sample & & & $\bar{A}$ & $\bar{A}$ & $B$ & A & $\bar{B}$ & $\mathrm{~A}$ \\
\hline $81001-O B$ & 7 & $\mathrm{pH} 3.6$ & 18.59 & & & 10.04 & 9.81 & 7.13 \\
\hline $81002-O B$ & 5 & $\mathrm{pH} 3.8$ & 18.01 & & & 9.92 & 9.98 & 7.13 \\
\hline $81003-O B$ & 6 & $\mathrm{pH} 3.9$ & 18.39 & & & 9.92 & 9.92 & 7.07 \\
\hline $81005-O B$ & 4 & $\mathrm{pH} 3.9$ & 18.79 & & & 10.04 & 9.92 & 7.18 \\
\hline $81005-O B$ & 5 & $\mathrm{pH} 3.3$ & 18.78 & & & 9.92 & 9.81 & 7.13 \\
\hline $81005-O B$ & 6 & $\mathrm{pH} 3.5$ & 18.39 & & & 9.92 & 9.92 & 7.13 \\
\hline $81005-O B$ & 7 & $\mathrm{pH} 6.0$ & 19.19 & & & 10.04 & 9.92 & 7.18 \\
\hline $80002-O B$ & 6 & $\mathrm{pH} \quad 6.9$ & 18.78 & & 13.58 & 9.60 & 9.98 & 7.13 \\
\hline $81002-O B$ & 7 & $\mathrm{pH} 7.2$ & 18.78 & & 14.24 & 9.92 & 10.09 & 7.13 \\
\hline $81002-O B$ & 12 & $\mathrm{pH} 7.4$ & 19.40 & & 13.58 & 9.87 & 9.92 & 7.18 \\
\hline $81003-O B$ & 4 & $\mathrm{pH} 5.4$ & 20.00 & & 14.01 & 10.27 & 9.92 & 7.30 \\
\hline $81003-O B$ & 5 & $\mathrm{pH} 5.7$ & 18.39 & & 13.68 & 9.92 & 9.92 & 7.07 \\
\hline $81006-O B$ & 4 & $\mathrm{pH} \quad 5.9$ & 19.61 & 14.24 & 13.79 & 10.04 & 10.04 & 7.18 \\
\hline $81006-O B$ & 5 & $\mathrm{pH} 7.8$ & 19.61 & 14.24 & 13.79 & 9.92 & 9.92 & 7.13 \\
\hline $81006-O B$ & 6 & $\mathrm{pH} 7.1$ & 19.61 & 14.47 & 13.68 & 9.92 & 9.92 & 7.07 \\
\hline $81006-O B$ & 11 & $\mathrm{pH} \quad 6.2$ & 18.37 & 14.01 & 13.79 & 9.92 & 9.81 & 7.07 \\
\hline $81006-O B$ & 12 & $\mathrm{pH} 5.6$ & 18.78 & & 13.58 & 9.92 & 9.92 & 7.13 \\
\hline $81006-O B$ & 13 & $\mathrm{pH} 6.6$ & 18.78 & & 14.01 & 9.81 & 10.04 & 7.07 \\
\hline $81006-O B$ & 14 & $\mathrm{pH} 7.3$ & 18.78 & & 13.79 & 9.92 & 9.92 & 7.07 \\
\hline
\end{tabular}


APPENDIX 3

CHEMICAL ANALYSES 


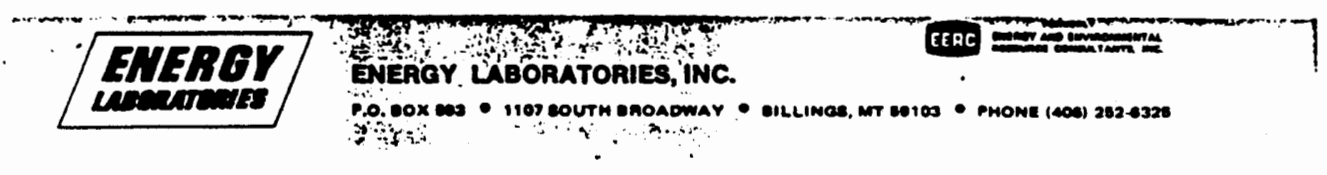

LABORATORY REPORT

Lab. No. $80-3338$

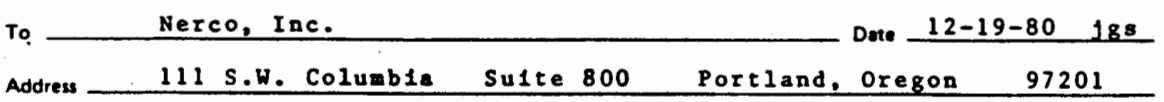

WYOMING SOIL OVERBURDEN / INTERBURDEN ANALYSIS

MINE

(Analysis by procedures recommended by Lend Quality Division Guidelines, Wyoming Department of Environmental Quality.)

\begin{tabular}{|c|c|c|c|c|c|c|c|c|c|}
\hline \multirow{4}{*}{$\begin{array}{l}\text { DJ } 80001 \\
\text { SAMPLE NO. } \\
\text { HOLE NO. } \\
\text { DEPTH. FT. }\end{array}$} & \multirow{3}{*}{$\begin{array}{c}1 \\
O B-1 \\
0-10\end{array}$} & \multirow{4}{*}{$\begin{array}{r}O B-2 \\
10-20\end{array}$} & \multirow{4}{*}{$\begin{array}{c}2 \\
O B-3 \\
20-30\end{array}$} & \multirow{4}{*}{$\begin{array}{c}3 \\
O B-4 \\
30-40\end{array}$} & \multirow{4}{*}{$\begin{array}{c}4 \\
0 B-5 \\
40-50\end{array}$} & \multirow{4}{*}{$\begin{array}{c}5 \\
O B-6 \\
50-60\end{array}$} & \multirow{3}{*}{$\begin{array}{c}6 \\
0 B-7 \\
60-72.6\end{array}$} & & \multirow{7}{*}{$\begin{array}{c}7 \\
\text { UB-1 } \\
96.9- \\
102.0 \\
7.0 \\
1.48 \\
50.4\end{array}$} \\
\hline & & & & & & & & & \\
\hline & & & & & & & & & \\
\hline & & & & & & & & & \\
\hline $\mathrm{PH}(1)$ & 7.3 & & 7.4 & 6.8 & 7.4 & 6.0 & 7.2 & & \\
\hline COND.. mmhos(2) & 2.59 & $\underset{\psi}{\Psi}$ & 4.06 & 3.34 & 3.35 & 3.77 & 3.28 & & \\
\hline SATUAATION, $x(1)$ & 25.1 & 옹 & 20.2 & 18.0 & 17.4 & 27.0 & 44.2 & & \\
\hline \multicolumn{9}{|l|}{ PAATICLE SIZE } & \\
\hline XSAND & 71 & s & 79 & 87 & 85 & 65 & 29 & $\stackrel{\omega}{E}$ & 19 \\
\hline * SILT & 19 & 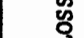 & 17 & 13 & 15 & 27 & 46 & 空 & 39 \\
\hline XCLAY & 10 & 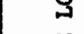 & 4 & $<2$ & $<2$ & 8 & 25 & 曾 & 42 \\
\hline $\begin{array}{l}\text { TEXTURE } \\
\text { CALCIUM }\end{array}$ & SL $_{13.5}$ & 宸 & LS & $\begin{array}{c}S \\
28,5\end{array}$ & 28 & SL, & $2 \frac{1}{3}$, & $\bar{n}$ & c \\
\hline $\begin{array}{l}\text { CALCIUM., mea/l/(3) } \\
\text { MAGNESIUM, mod/i(3) }\end{array}$ & $\begin{array}{l}13.5 \\
10.2\end{array}$ & 8 & $\begin{array}{l}30.2 \\
11.5\end{array}$ & $\begin{array}{l}28.5 \\
11.5\end{array}$ & $\begin{array}{l}28.3 \\
11.2\end{array}$ & $\begin{array}{l}29.7 \\
20.4\end{array}$ & $\begin{array}{l}23.2 \\
17.2\end{array}$ & 녈 & $\begin{array}{l}9.09 \\
4.87\end{array}$ \\
\hline SODIUM, $\bmod / 1(3)$ & 5.39 & 1 & 9.38 & 4.71 & 4.91 & 2.71 & 1.77 & $\overline{\mathbf{z}}$ & 1.07 \\
\hline $\operatorname{SAA}(4)$ & 1.60 & 2 & 2.05 & 1.05 & 1.11 & 0.54 & 0.39 & 0 & 0.41 \\
\hline ESP & 1.26 & E & 1.97 & 1.38 & 1.53 & 0.66 & 0.34 & 家 & 0.24 \\
\hline $\begin{array}{l}\text { LIME(B) } \\
\text { COPPER DPR }\end{array}$ & $\begin{array}{l}2.6 \\
0.5\end{array}$ & 㽞 & 1.7 & 22.0 & $\begin{array}{r}12.1 \\
0.4\end{array}$ & 1.0 & 0.9 & & 1.4 \\
\hline SELENIUM, DPPT(B) & 0.04 & ต & $\begin{array}{l}0.4 \\
0.10\end{array}$ & $\begin{array}{l}0.3 \\
<0.02\end{array}$ & $<0.4$ & $\begin{array}{l}1.7 \\
<0.02\end{array}$ & $\begin{array}{l}2.0 \\
0.22\end{array}$ & & $\begin{array}{l}4.9 \\
0.28\end{array}$ \\
\hline BORON, pDom (6) & 0.2 & 曼 & 0.3 & 0.4 & 0.4 & 0.4 & 0.3 & & 0.7 \\
\hline $\begin{array}{l}\text { NITAATE-N, pom } \\
\text { MOLYOENUM, Dom (7) }\end{array}$ & 1.8 & $\sum_{3}^{\circ}$ & 31 & 2.6 & 2.9 & 1.5 & 1.0 & & $<1.0$ \\
\hline POT. ACIDITY (8) & $<1$ & $\begin{array}{l}n \\
0\end{array}$ & $\begin{array}{l}<0.05 \\
<1\end{array}$ & $<_{1}^{0.13}$ & 0.05 & 0.06 & 0.29 & & 0.14 \\
\hline NEUT POT (9) & & $\mathbf{z}$ & 17 & 22 & 121 & 10 & 9.00 & & 14 \\
\hline ACID BASE POT. & +26 & & +17 & +22 & +121 & +10 & +7.5 & & +14 \\
\hline
\end{tabular}

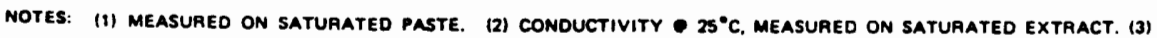
MEASIIAED ON SATURATED EXTAACT. (4) SODIUM ABSORPTION AATIO. (5) QUALITATIVE BY EFFERVESCENCE, SL - SLIGHTLY CALCAREOUS, MOD - MODERATELY CALCAREOUS, HI - HIGHLY CALCAREOUS. (6) WATER SOLUBLE. (7) MEASUAED AFTER $\left(\mathrm{NH}_{4}\right)_{2} \mathrm{CO}_{3}$ EXTRACTION. (8) MEQ. H $\mathrm{H}^{+}$PER $100 \mathrm{~g}$. (9) TONS $\mathrm{CaCO}_{3} / 1000$ TONS DRY MATERIAL. (10) TONS $\mathrm{CaCO}_{3} / 1000$ TONS DRY MATERIAL. \#USDA TEXTURAL CLASS KEY:

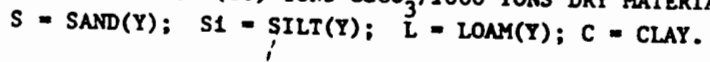




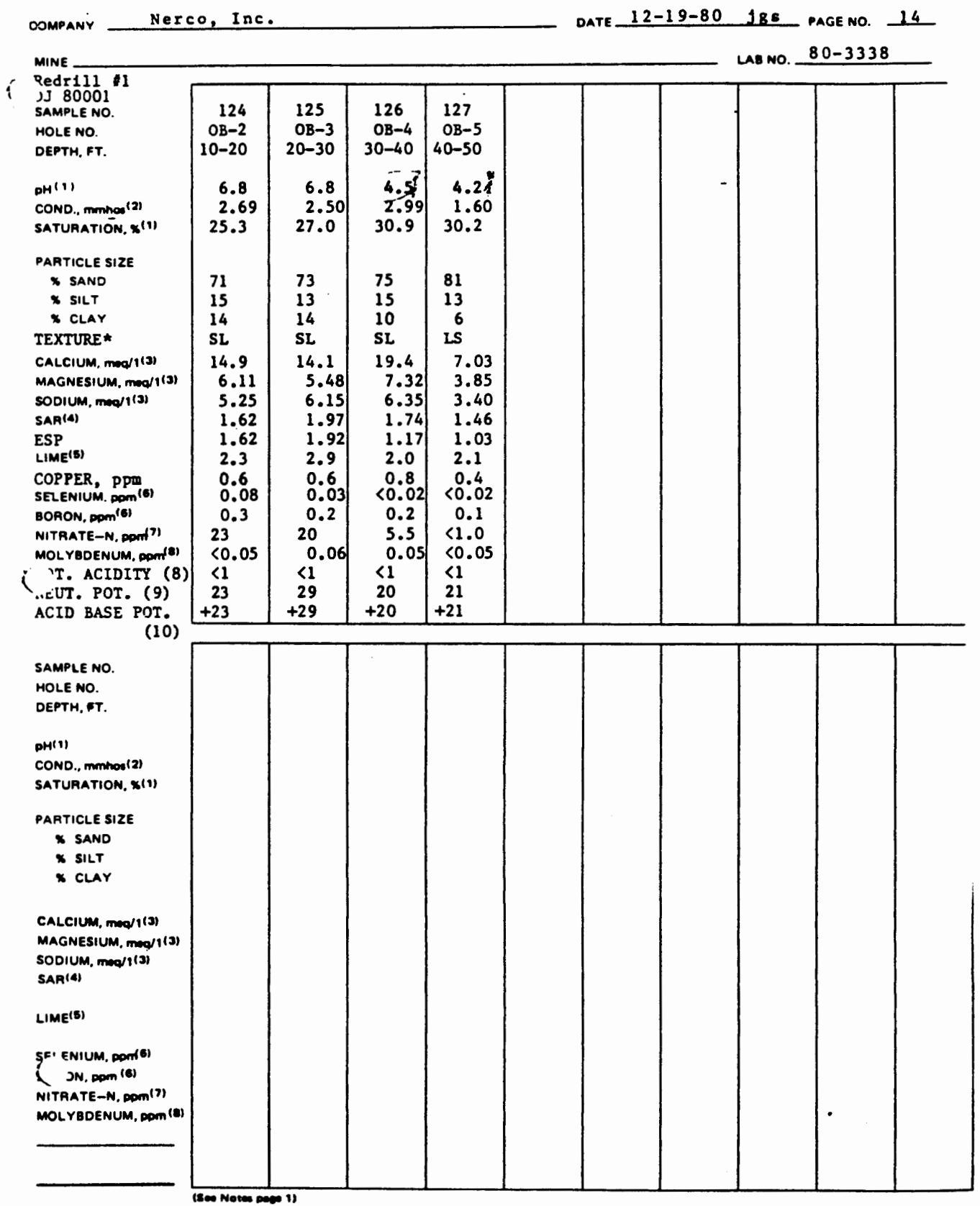




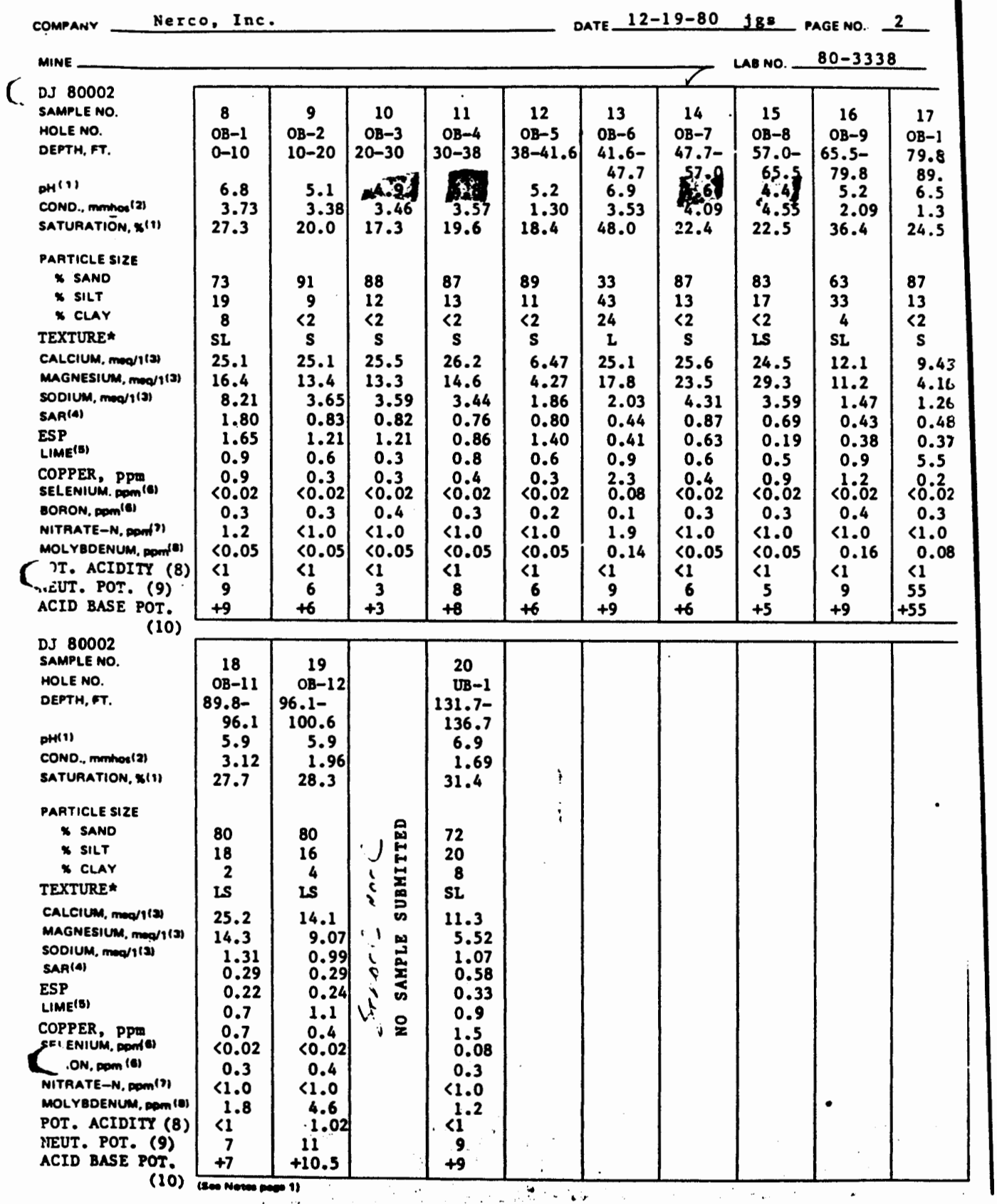




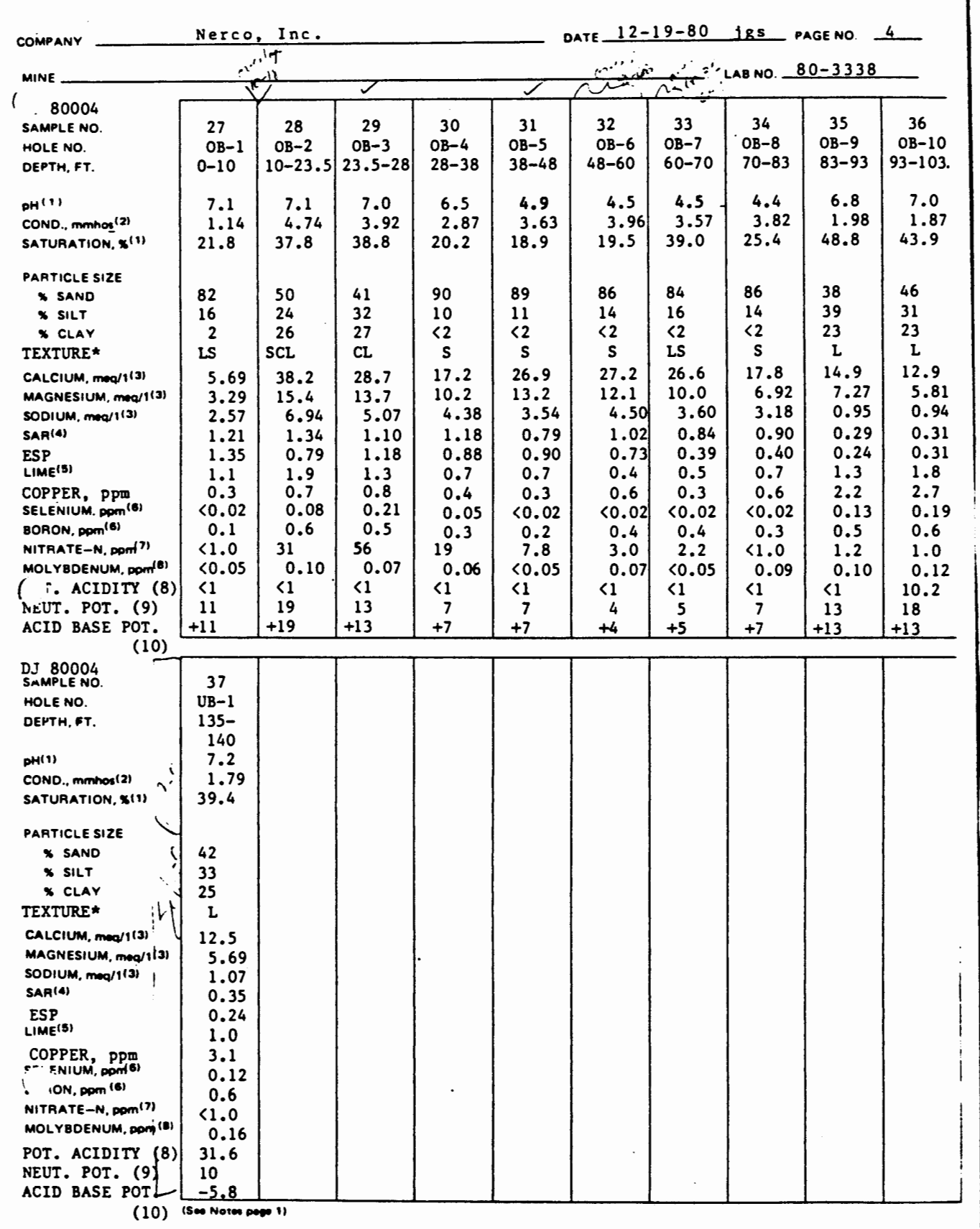




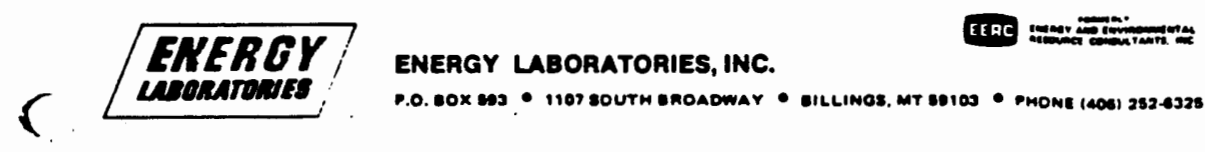

LABORATORY REPORT
TO NERCO, INC.
MINE
WYOMING SOIL OVERBURDEN / INTERBURDEN ANALYSIS
Dave JOhnSton

(Analysis by procedures recommended by Land Qublity Division Guidelines, Wyoming Department of Environmental Quality.)

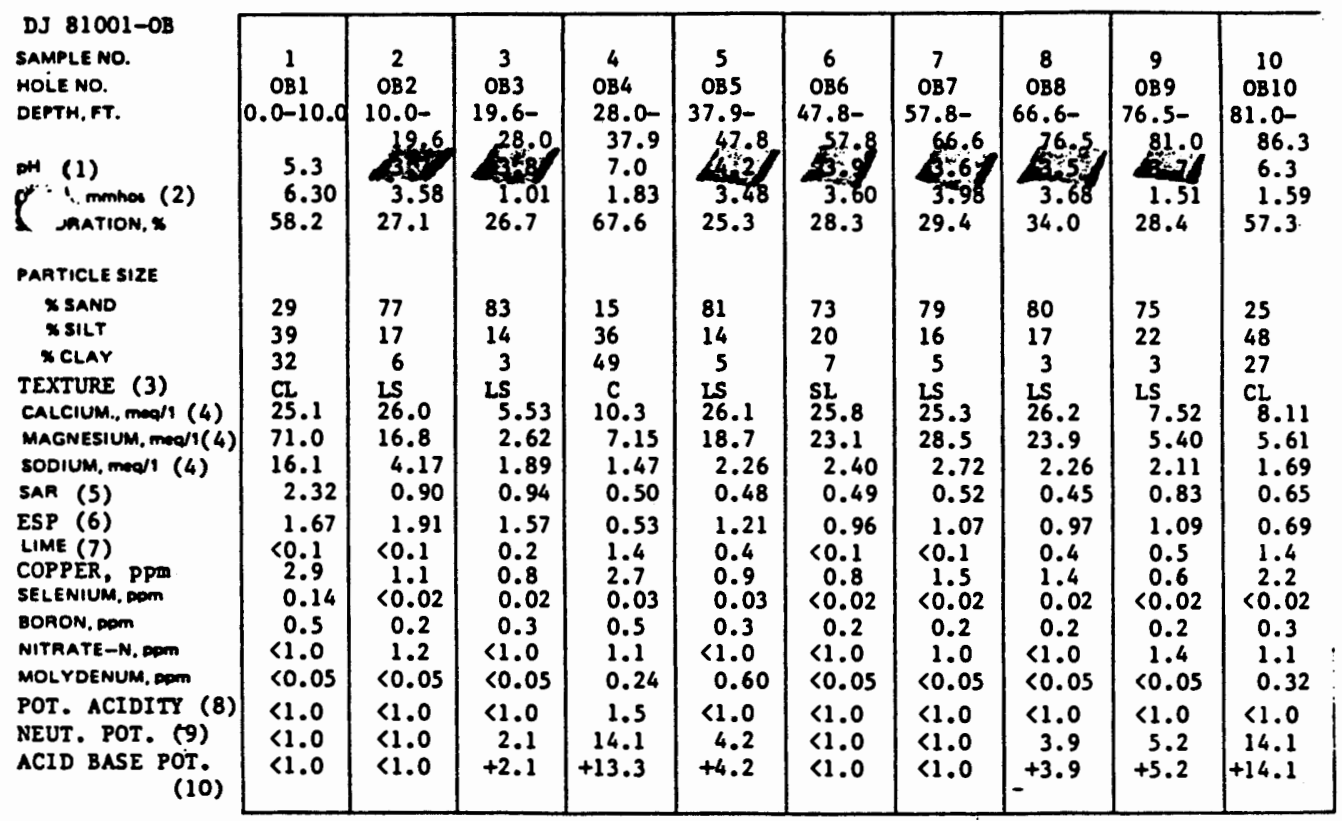

(- NOTES: (1) MEASURED ON SATURATED PASTE. (2) CONDUCTIVITY, mos $/ \mathrm{cm}$ e $25^{\circ} \mathrm{C}$, MEASURED ON SATURATED EXTRACT. (3) USDA TEXTURAL CLASS. KEY: S=SAND(Y); Si=SILT(Y); L-LOAM(Y); C=CLAY. (4) MEASURED ON SATURATED EXTRACT. (5) SODIUM ABSORPIION RATTO. (6) EXCHANGEABLE SODIUS PERCENTAGE. (7) $\%$ AS $\mathrm{CaCO}_{3}$ (8) MEQ. H ${ }^{+}$PER $100 \mathrm{~g}$. (9) TONS $\mathrm{CaCO}_{3} / 1000$ TONS DRY MATERIAL. (10) TONS $\mathrm{CaCO}_{3} / 1000$ TONS DRY MATERIAL + - LIME EXCESS: - - LIME DEFICIENCY. 


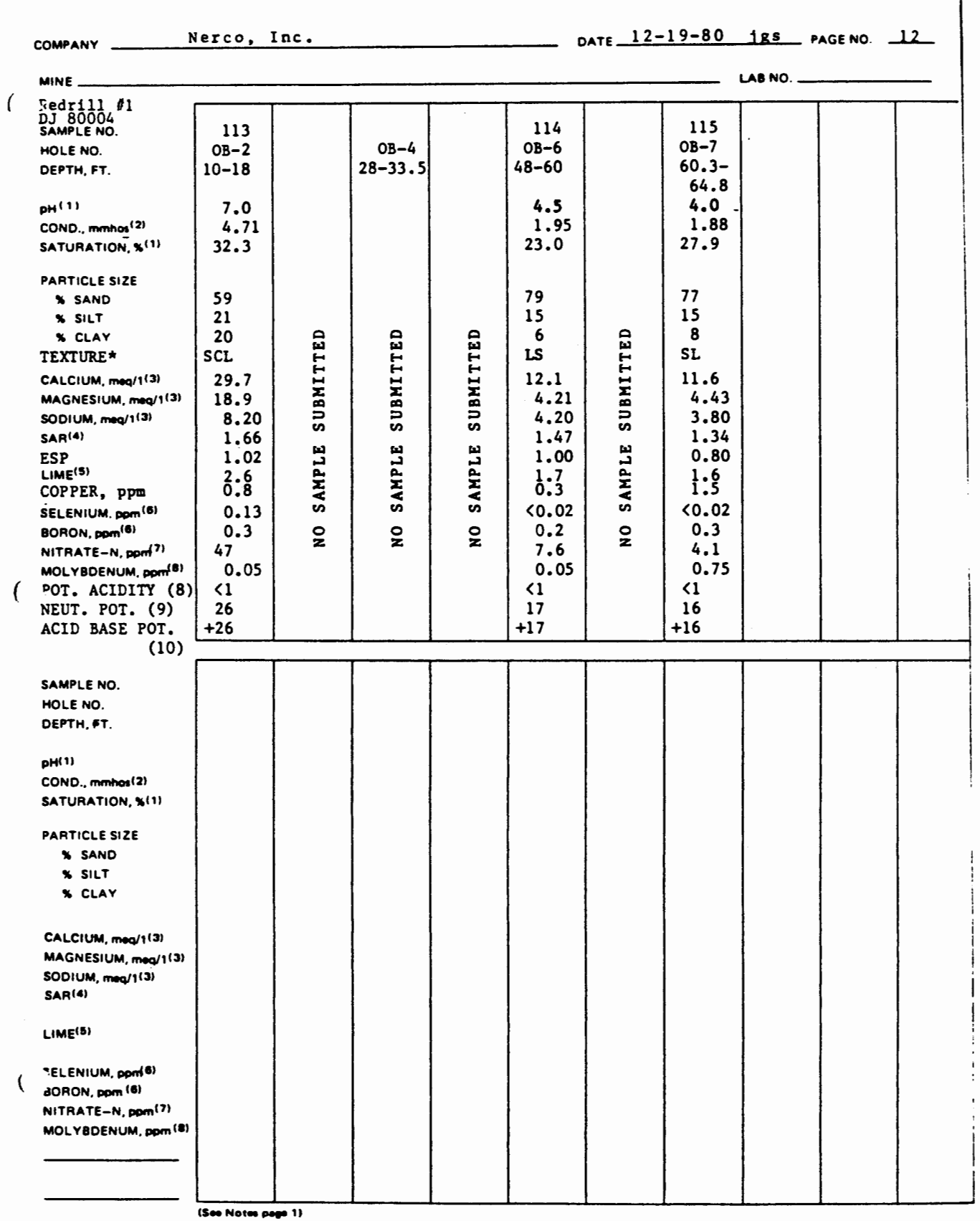




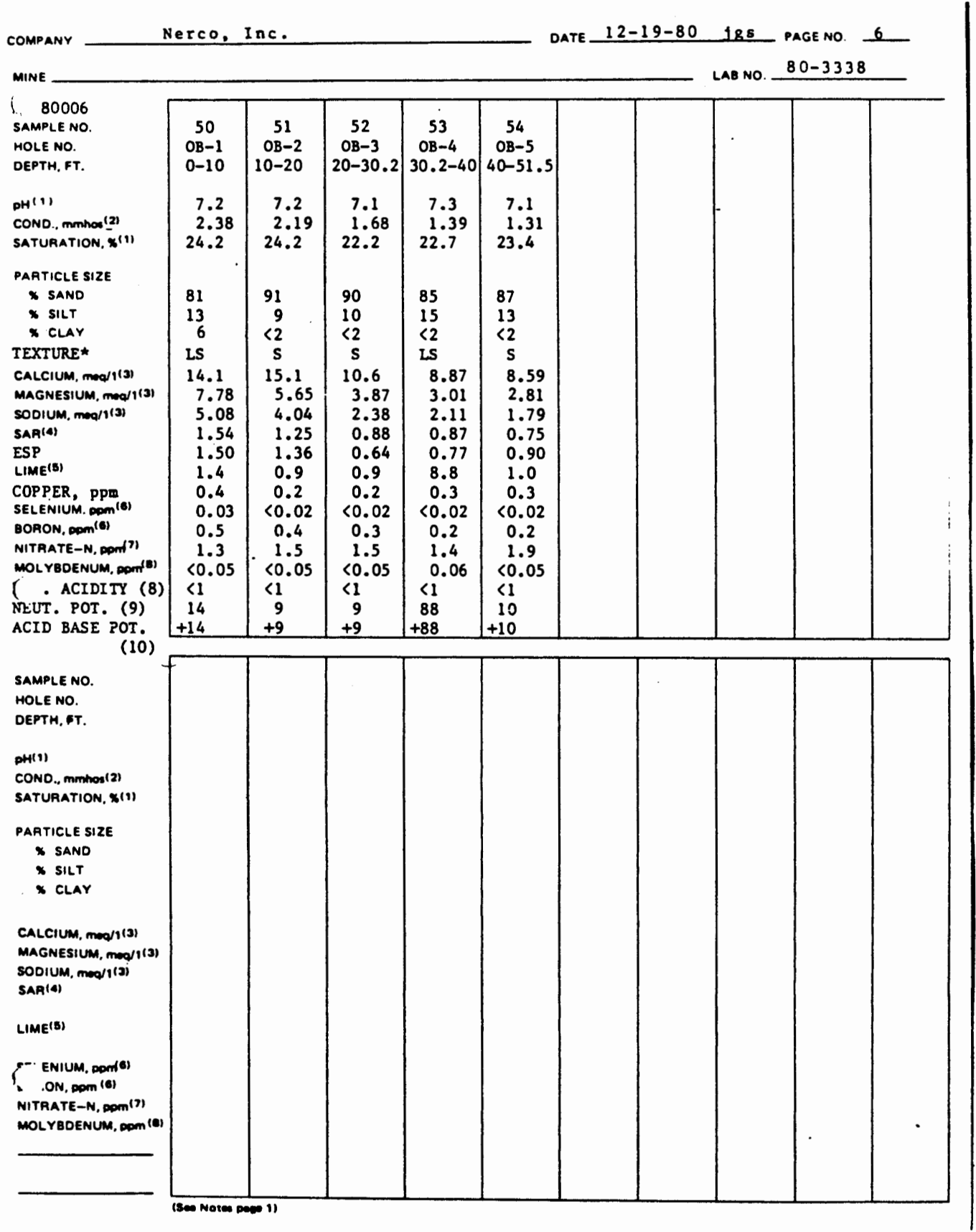




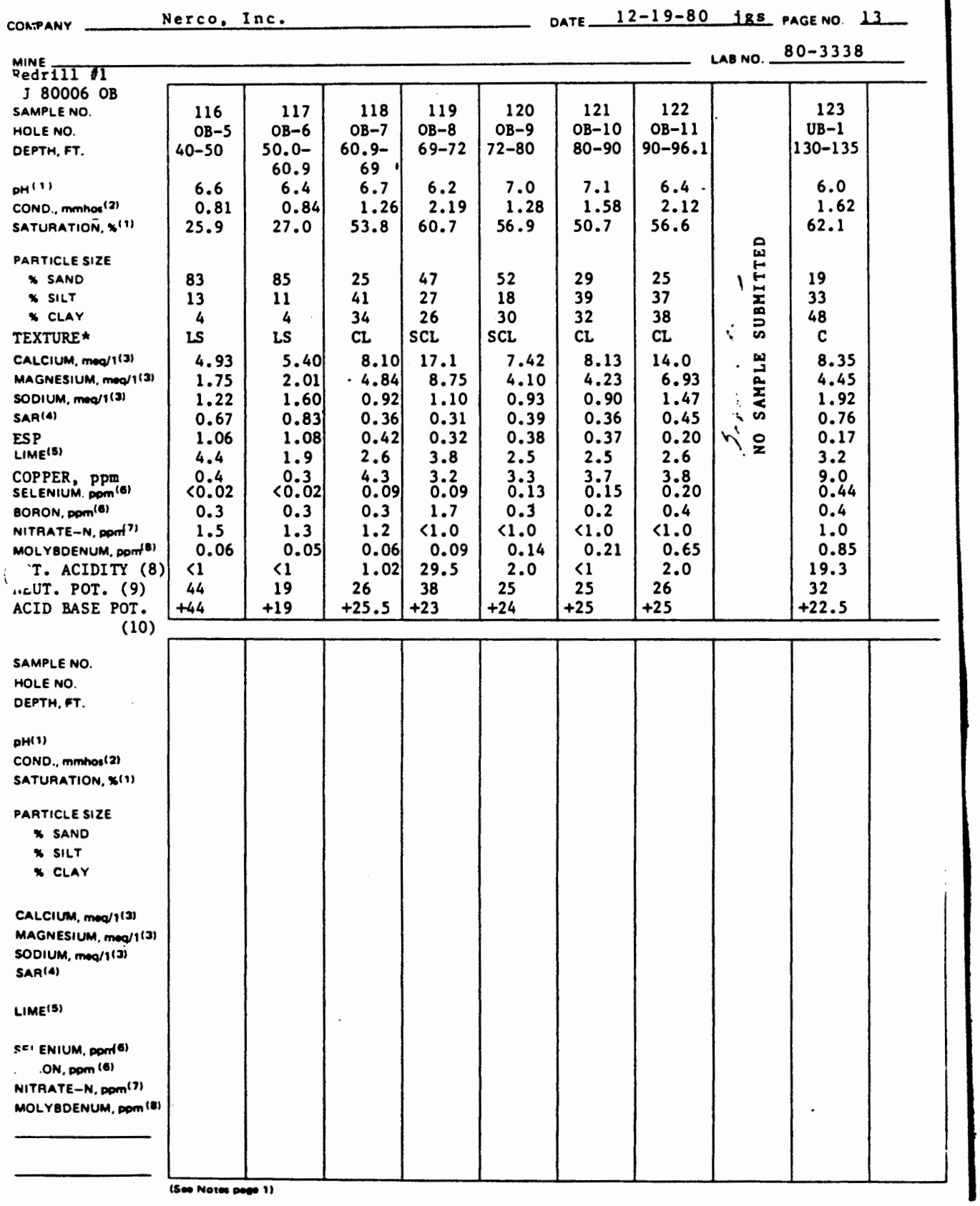


ENERGY LABORATORIES, INC.

ETRC

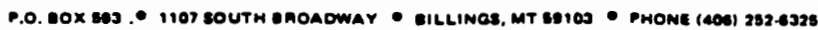

\section{LABORATORY REPORT}

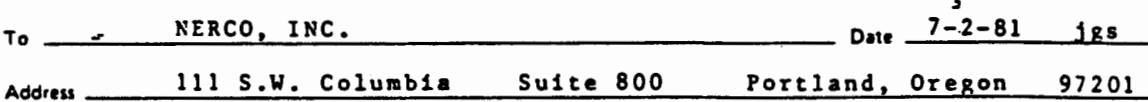

WYOMING SOIL OVERBURDEN / INTERBURDEN ANALYSIS

MINE

Dave Johnston

(Analysis by procedures recommended by Land Quality Division Guidelines, Wyoming Department of Environmental Qualioy.)

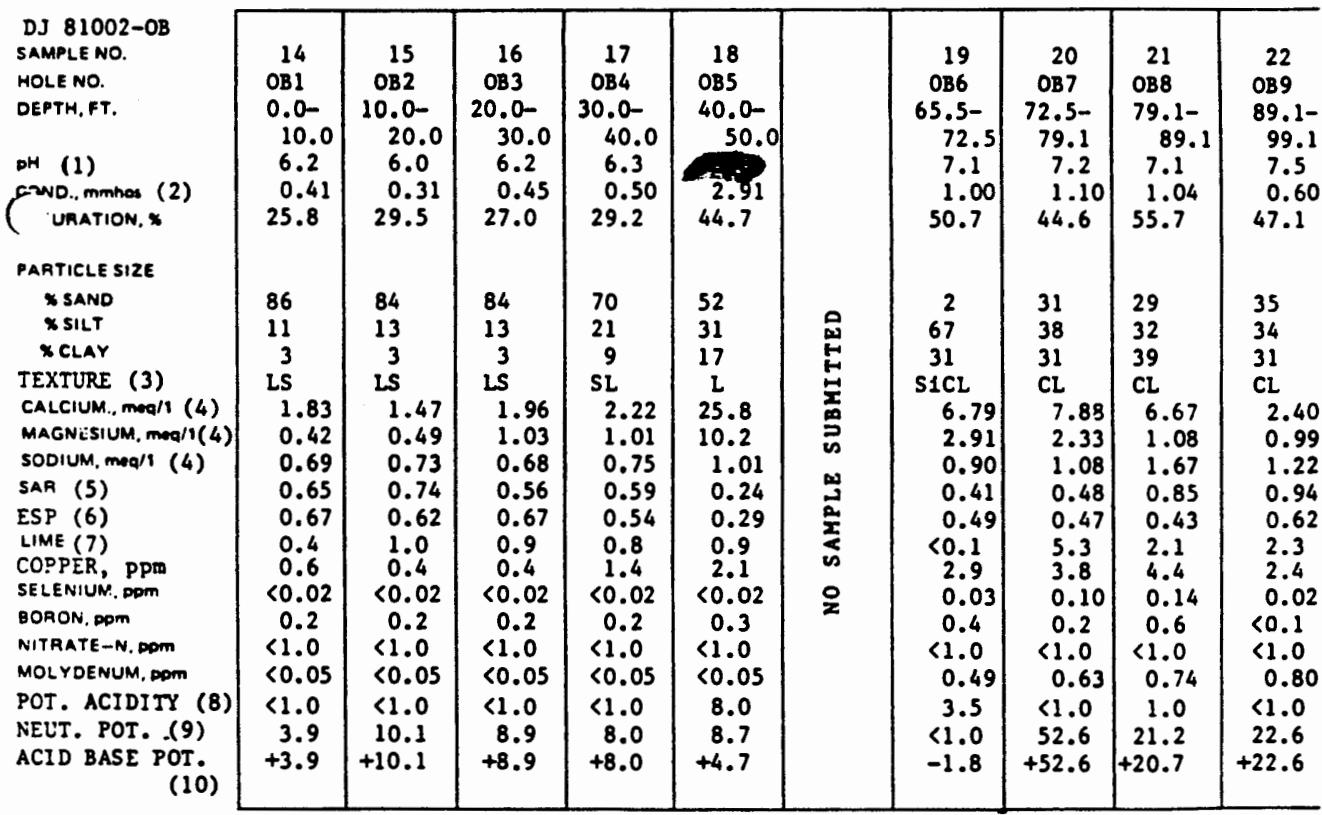

NOTES: (1) MEASURED ON SATURATED PASTE. (2) CONDUCTIVITY, TOROS/ $\mathrm{cm} 25^{\circ} \mathrm{C}$, MEASURED ON SATURATED EXTRACT. (3) USDA TEXTURAL CLASS. KEY: S=SAND(Y); Si=SILT(Y); L-LOAM(Y); C-CLAY. (4) MEASURED ON SATURATED EXTRACT. (5) SODIUN ABSORPTION RATIO. (6) EXCHANGEABLE SODIUM PERCENTAGE. (7) \% AS $\mathrm{CaCO}_{3}$ (8) MEQ. $\mathrm{H}^{+}$PER 1008. (9) TONS $\mathrm{CaCO}_{3} / 1000$ TONS DRY MATERIAL. (10) TONS $\mathrm{CaCO}_{3} / 1000$ TONS DRY MATERIAL. + - LIME EXCESS: - - LIME DEFICIENCY. 


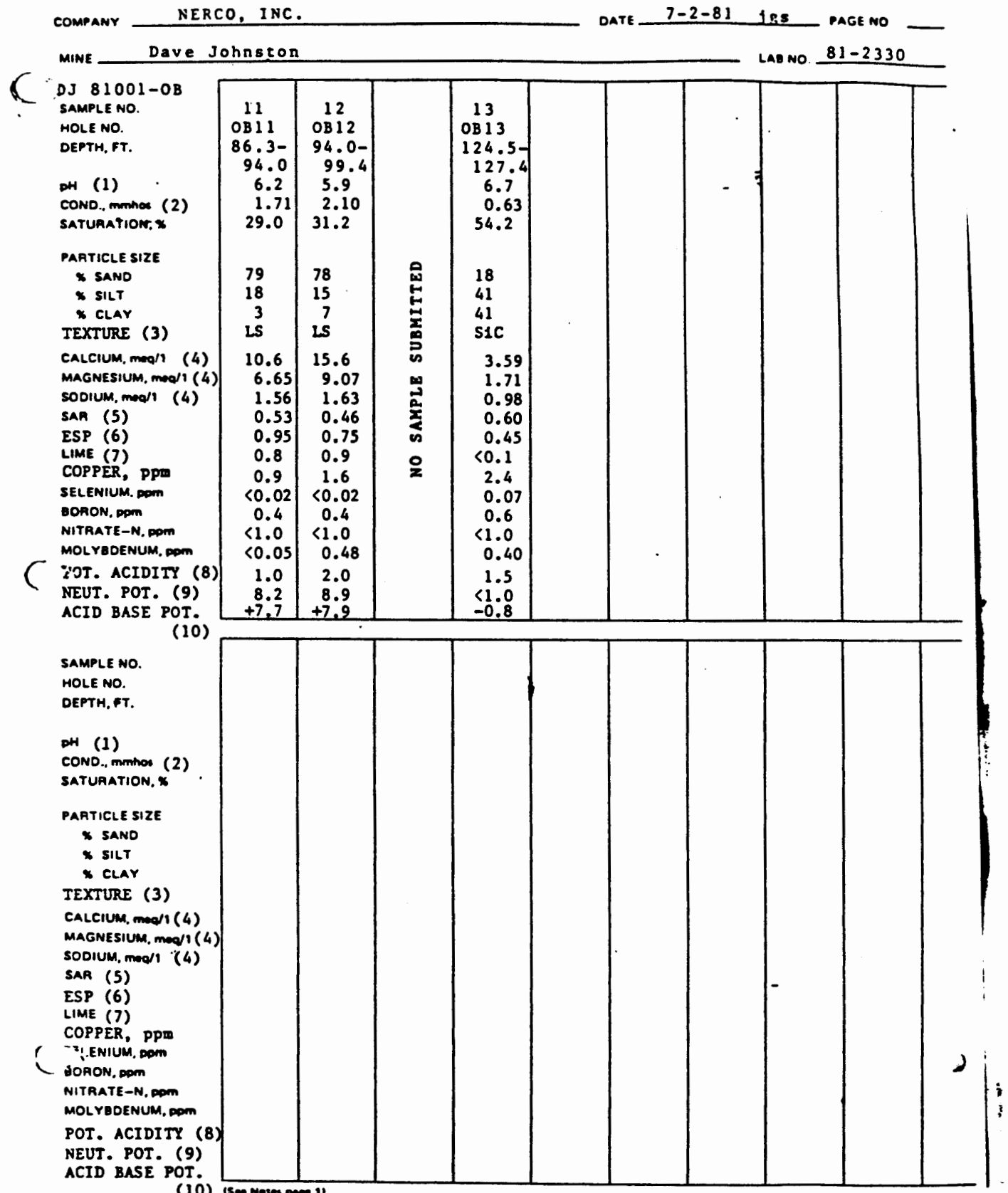




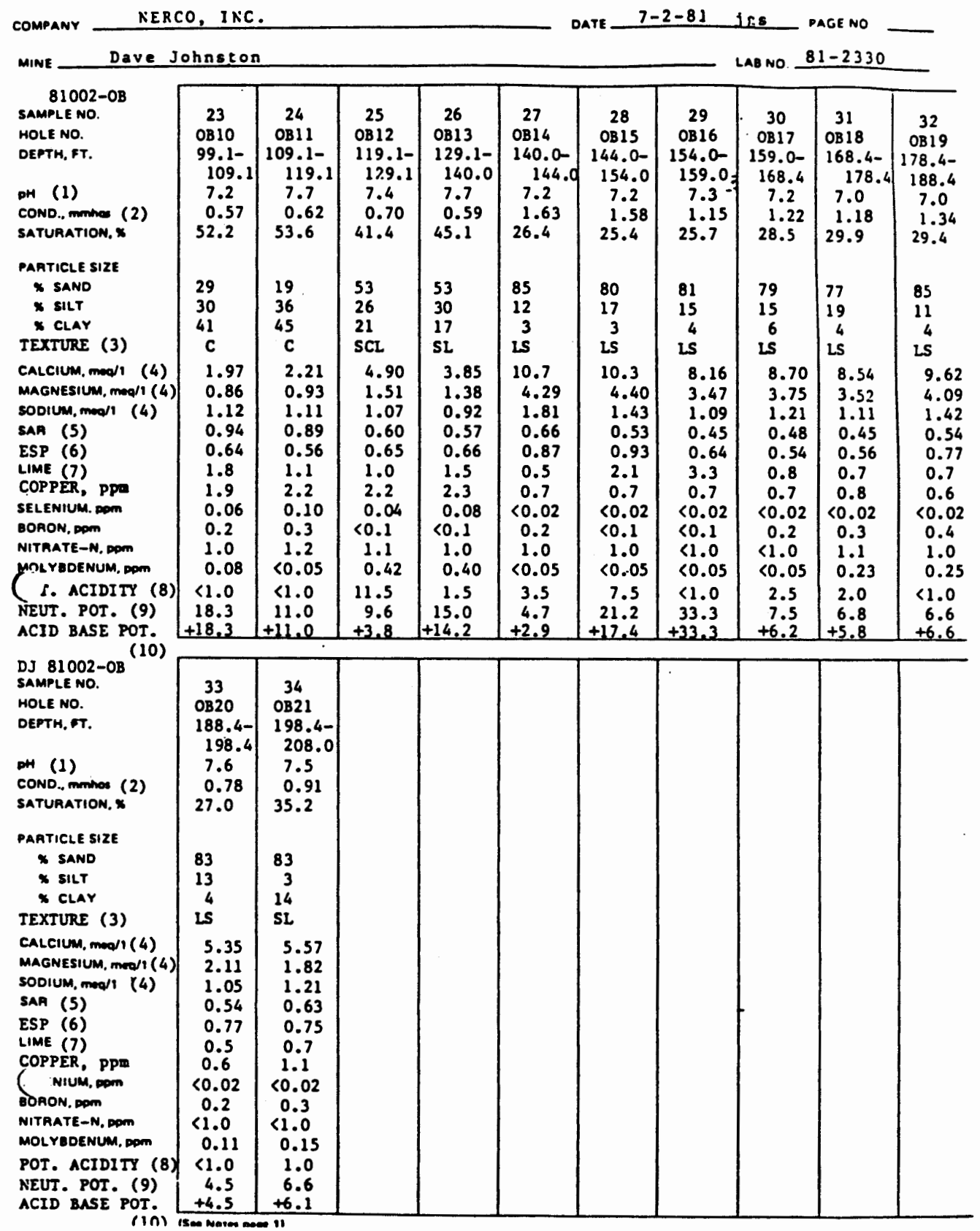



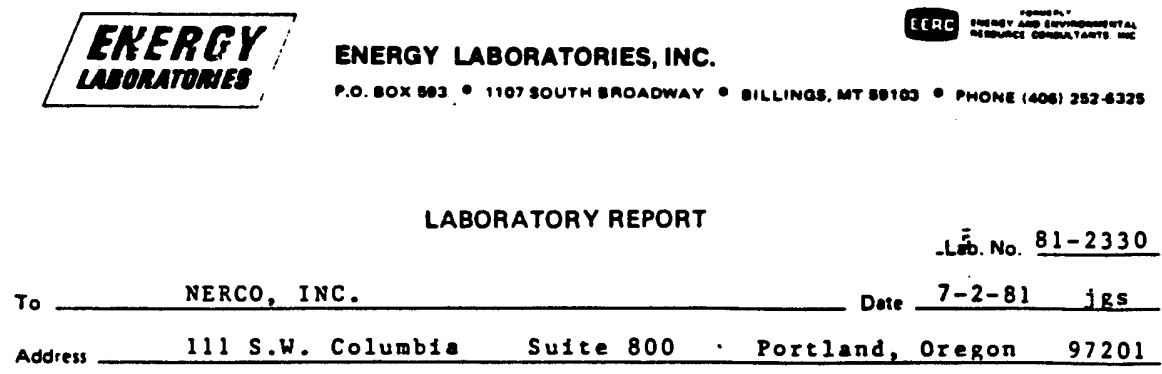

WYOMING SOIL OVERBURDEN / INTERBURDEN ANALYSIS

MINE Dave Johnston

(Analysis by procedures recommended by Land Quality Division Guidelines, Wyoming Department of Environmental Quality.)

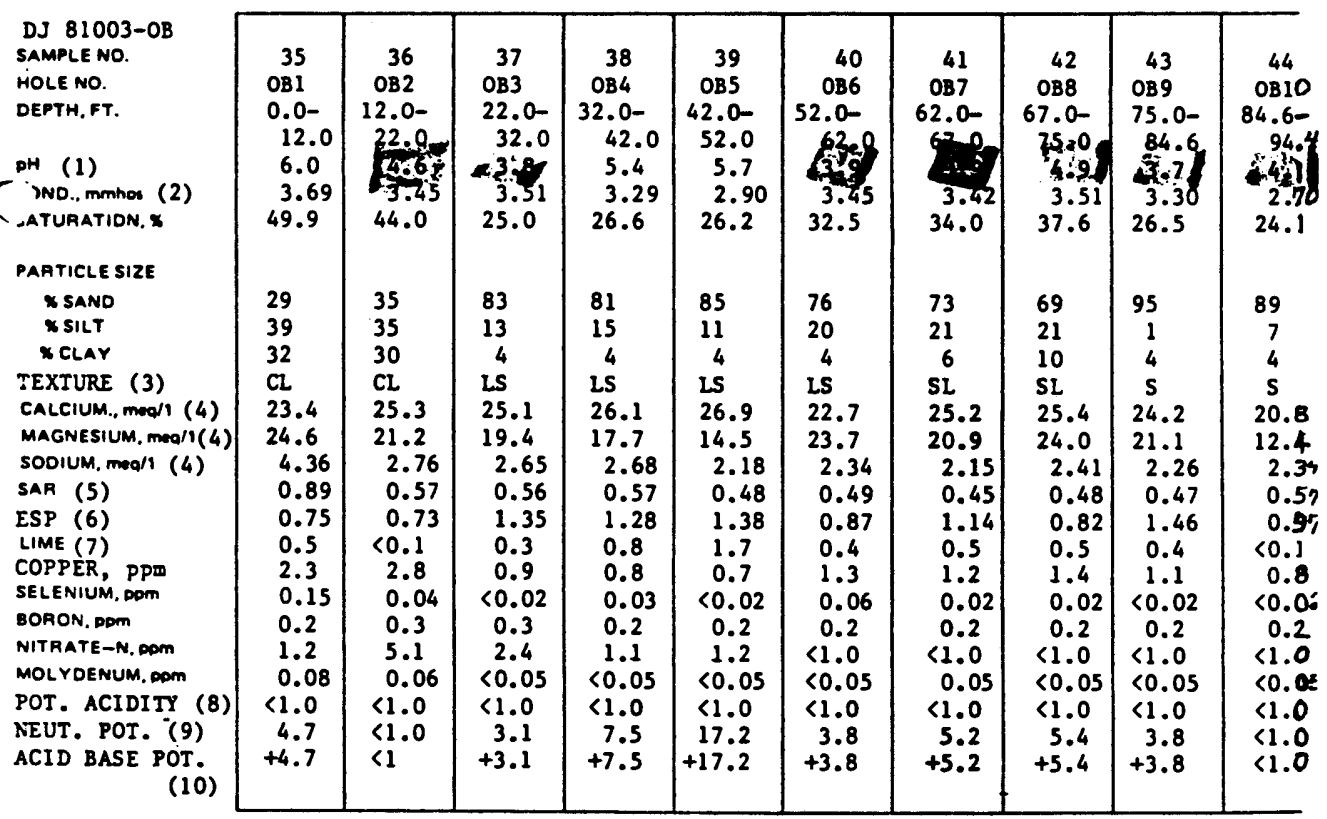

NOTES: (1) MEASUREd ON SATURATEd PASTE. (2) CONDUCTIVITI, mohos/cm e $25^{\circ} \mathrm{C}$, MEASUREd 0 SATURATED EXTRACT. (3) USDA TEXTURAL CLASS, KEY: S=SAND(Y); SI=SILT(Y); L=LOAM(Y); C=CLAY. (4) MEASURED ON SATURATED EXTRACT. (5) SODI UM ABSSORPIION RATIO. (6) EXCHANGEABLE SODIUM PERCENTAGE. (7) $\%$ AS CaCO $\mathrm{CO}_{3}$ (8) MEQ. H $\mathrm{H}^{+}$PER 100 ( 9 ) TONS $\mathrm{CaCO}_{3} / 1000$ TONS DRY MATERIAL. (10) TONS $\mathrm{CaCO}_{3} / 1000$ TONS DRY MATERIAL + - LIME EXCESS: - - LIME DEFICIENCY. 


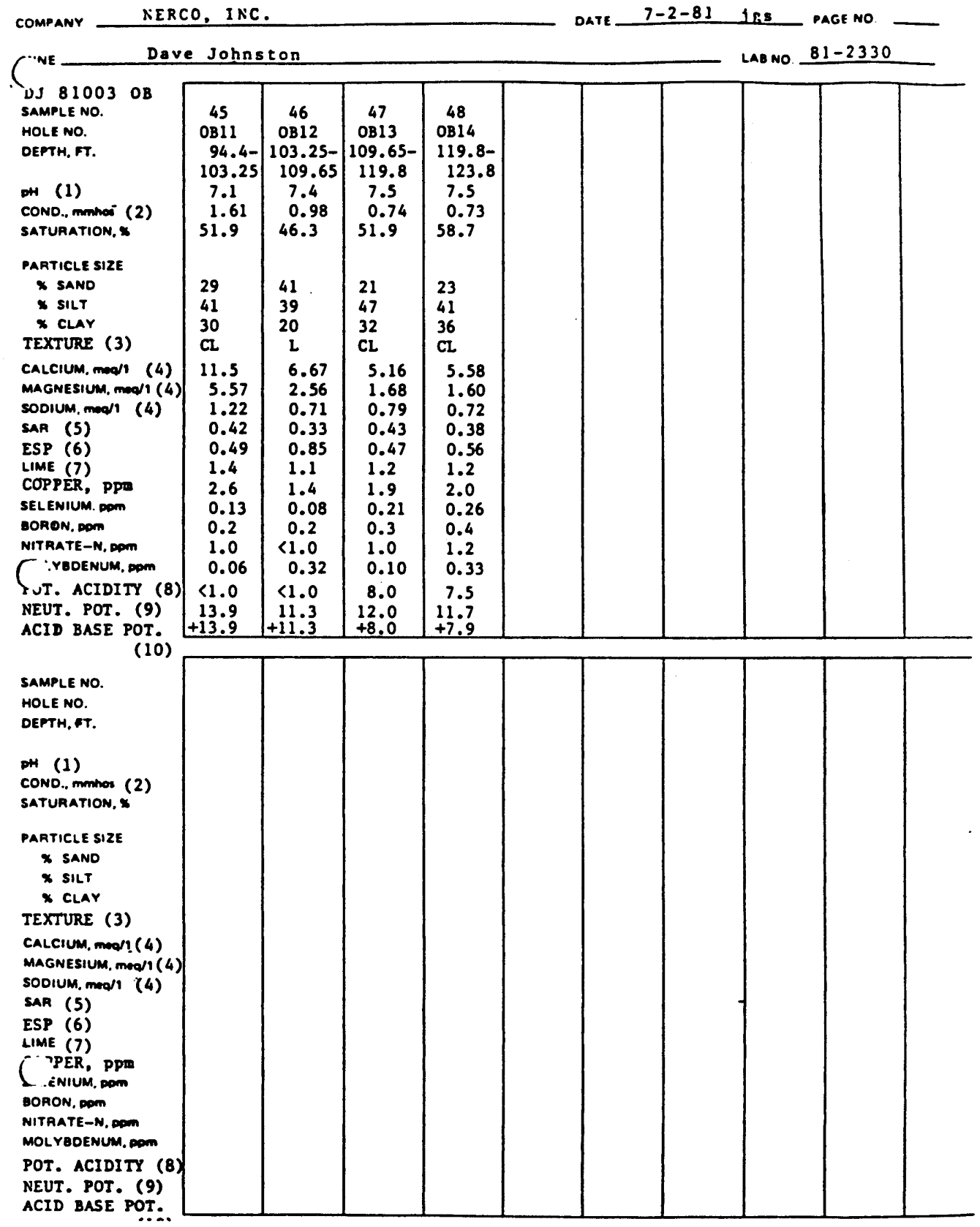



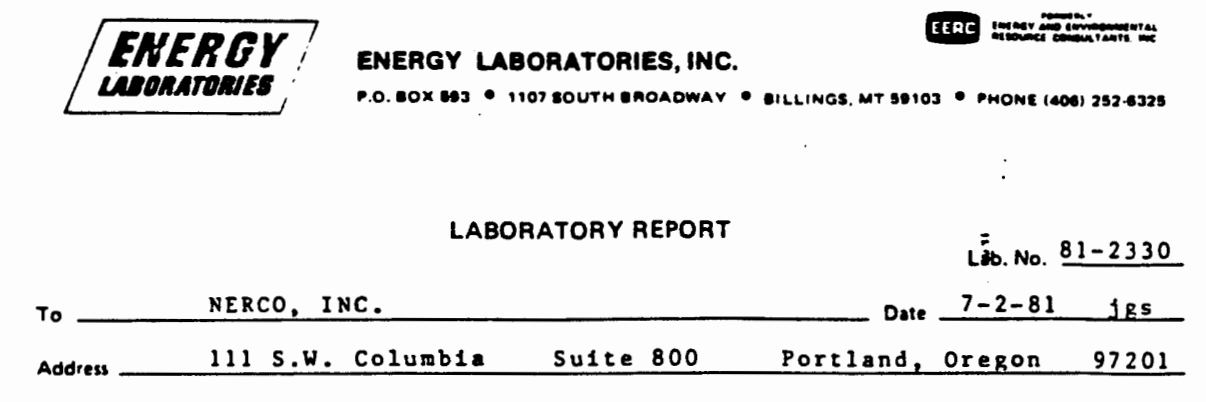

WYOMING SOIL OVERBURDEN / INTERBURDEN ANALYSIS

MINE

Dave Johnston

(Analysis by procedures recommended by Land Quatity Division Guidelines. Wyoming Department of Environmental Quality.)

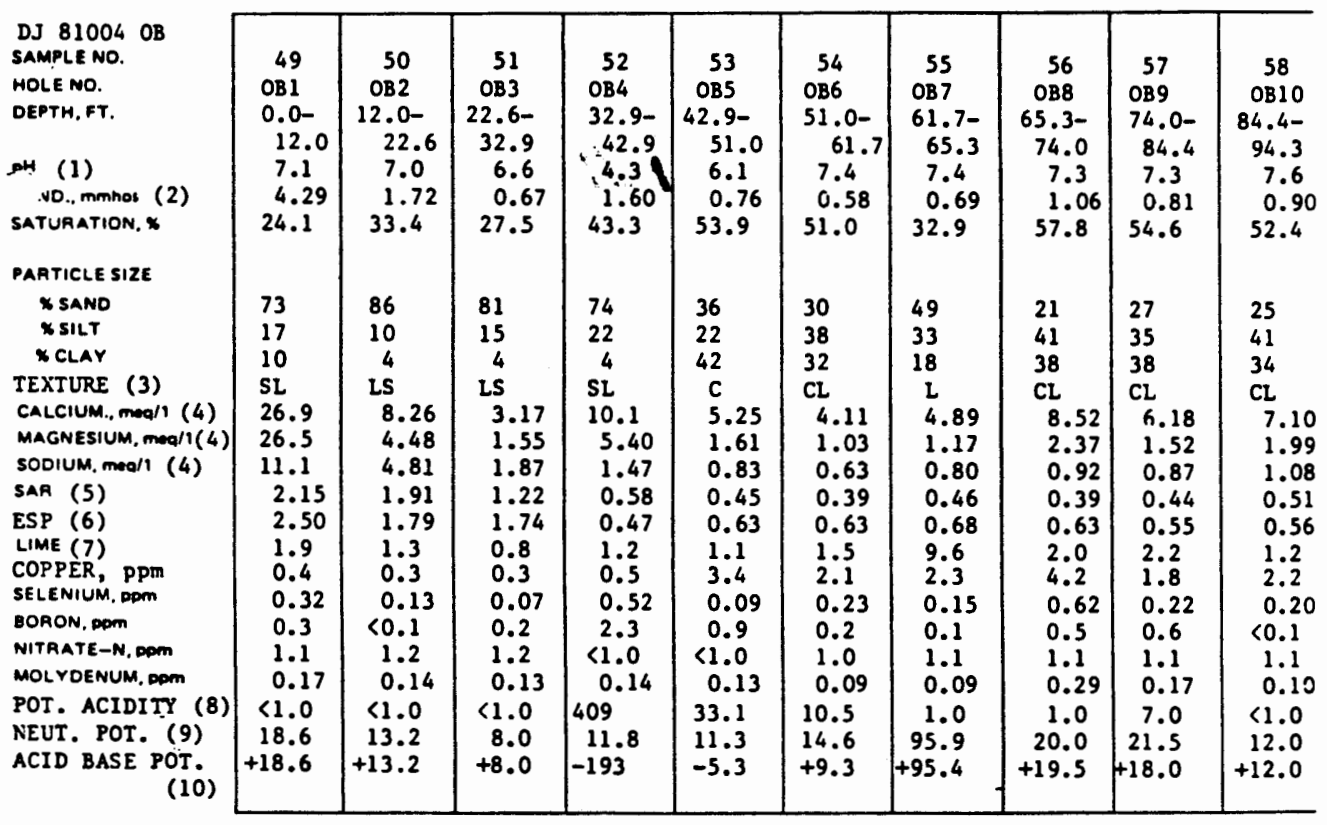

NOTES: (1) MEASURED ON SATURATED PASTE. (2) CONDUCTIVITY, mhos/cm $25^{\circ} \mathrm{C}$, MEASURED ON SATURATED EXTRACT. (3) USDA. TEXTURAL CLASS. KEY: S=SAND(Y); Si=SILT(Y); L=LOAM(Y): C=CLAY. (4) MEASURED ON SATURATED EXTRACT. (5) SODIUM ABSORPTIO:: RATIO. (6) EXCHANGEABLE SODIUM PERCENTAGE. (7) \% AS CaCO (8) MEQ. H PER 100 E (9) TONS $\mathrm{CaCO}_{3} / 1000$ TONS DRY MATERIAL. (10) TONS $\mathrm{CaCO}_{3} / 1000$ TONS DRY MATERTAL + - LIME EXCESS: - - LIME DEFICIENCY. 


\begin{tabular}{|c|c|c|c|c|c|c|c|c|c|c|}
\hline \multicolumn{6}{|l|}{ COMPANY - } & \multicolumn{2}{|c|}{ DATE $7-2-81$} & \multirow{2}{*}{\multicolumn{3}{|c|}{$\begin{array}{l}\text { IFS PAGE NO } \\
\text { LAB NO. 81-2330 }\end{array}$}} \\
\hline \multicolumn{8}{|c|}{ Dave Johnston } & & & \\
\hline $\begin{array}{l}\text { DJ } 81004 \text { OB } \\
\text { SAMPLE NO. } \\
\text { HOLE NO. } \\
\text { DEPTH. FT. } \\
\text { DH (1) } \\
\text { CONO., mminOA (2) } \\
\text { SATUAATION, } \%\end{array}$ & $\begin{array}{c}59 \\
0 B 11 \\
94.3- \\
105.0 \\
7.7 \\
0.76 \\
46.2\end{array}$ & $\begin{array}{c}60 \\
0 B 12 \\
105.0- \\
115.0 \\
7.3 \\
1.94 \\
33.6\end{array}$ & $\begin{array}{c}61 \\
\text { OB13 } \\
115.0 \\
125.0 \\
7.2 \\
1.40 \\
28.9\end{array}$ & $\begin{array}{c}62 \\
\text { OB14 } \\
125.0- \\
135.0 \\
7.4 \\
1.09 \\
30.2\end{array}$ & $\begin{array}{c}63 \\
\text { OB15 } \\
135.0- \\
145.0 \\
7.2 \\
1.42 \\
26.9\end{array}$ & $\begin{array}{l}64 \\
\text { OB16 } \\
145.0- \\
155.0 \\
6.8 \\
2.10 \\
28.4\end{array}$ & $\begin{array}{c}65 \\
\text { OB17 } \\
155.0- \\
161.0 \\
6.7 \\
2.29 \\
32.3\end{array}$ & $\begin{array}{c}66 \\
\text { OB18 } \\
161.0- \\
164.7 \\
7.1 \\
1.49 \\
50.7\end{array}$ & $\begin{array}{l}67 \\
\text { OB19 } \\
164.7- \\
175.0 \\
7.3 \\
1.21 \\
27.9\end{array}$ & $\begin{array}{c}68 \\
\text { OB20 } \\
175.0- \\
185.0 \\
7.2 \\
1.71 \\
34.1\end{array}$ \\
\hline $\begin{array}{l}\text { PARTICLE SIZE } \\
\text { X SAND } \\
\text { \% SILT } \\
\text { \% CLAY } \\
\text { TEXTURE (3) }\end{array}$ & $\begin{array}{r}47 \\
31 \\
22 \\
L\end{array}$ & $\begin{array}{r}78 \\
16 \\
6 \\
25\end{array}$ & $\begin{array}{r}84 \\
12 \\
4 \\
25\end{array}$ & $\begin{array}{c}82 \\
14 \\
4 \\
25\end{array}$ & $\begin{array}{r}79 \\
13 \\
8 \\
L S\end{array}$ & $\begin{array}{r}78 \\
16 \\
6 \\
L S\end{array}$ & $\begin{array}{r}77 \\
19 \\
4 \\
15\end{array}$ & $\begin{array}{r}38 \\
48 \\
14 \\
2\end{array}$ & $\begin{array}{r}79 \\
13 \\
8 \\
25\end{array}$ & $\begin{array}{l}65 \\
25 \\
10 \\
\text { SL }\end{array}$ \\
\hline 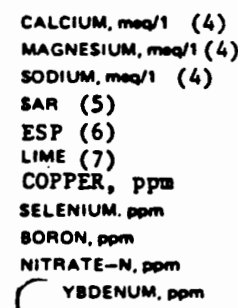 & $\begin{array}{l}5.95 \\
1.33 \\
0.82 \\
0.43 \\
0.70 \\
1.2 \\
1.9 \\
0.40 \\
<0.1 \\
1.0 \\
0.14\end{array}$ & $\begin{array}{l}15.2 \\
4.81 \\
1.82 \\
0.58 \\
0.91 \\
0.9 \\
0.7 \\
0.40 \\
0.2 \\
1.1 \\
0.10\end{array}$ & $\begin{array}{l}10.7 \\
3.09 \\
1.74 \\
0.66 \\
0.83 \\
1.1 \\
0.3 \\
0.03 \\
0.1 \\
1.0 \\
0.11\end{array}$ & $\begin{array}{l}7.91 \\
1.90 \\
1.62 \\
0.73 \\
0.90 \\
1.0 \\
0.3 \\
<0.02 \\
<0.1 \\
<1.0 \\
0.07\end{array}$ & $\begin{array}{l}11.3 \\
3.08 \\
1.68 \\
0.63 \\
0.84 \\
1.3 \\
0.4 \\
<0.02 \\
0.1 \\
1.0 \\
0.05\end{array}$ & $\begin{array}{l}16.6 \\
5.75 \\
1.64 \\
0.49 \\
0.52 \\
0.9 \\
0.3 \\
0.02 \\
0.2 \\
<1.0 \\
0.05\end{array}$ & $\begin{array}{l}17.6 \\
6.72 \\
1.84 \\
0.53 \\
0.60 \\
1.1 \\
0.7 \\
0.05 \\
0.5 \\
1.1 \\
0.05\end{array}$ & $\begin{array}{l}10.7 \\
4.40 \\
0.76 \\
0.28 \\
0.52 \\
1.5 \\
2.2 \\
0.21 \\
0.2 \\
1.0 \\
0.07\end{array}$ & $\begin{array}{l}8.35 \\
4.66 \\
1.02 \\
0.40 \\
0.65 \\
0.7 \\
0.4 \\
0.03 \\
0.2 \\
1.2 \\
0.08\end{array}$ & $\begin{array}{l}11.2 \\
5.85 \\
1.69 \\
0.58 \\
0.46 \\
1.3 \\
1.0 \\
0.05 \\
0.2 \\
1.1 \\
0.08\end{array}$ \\
\hline $\begin{array}{l}\text { FUT. ACIDITY ( } 8 \text { ) } \\
\text { NEUT. POT. ( } 9 \text { ) } \\
\text { ACID BASE POT. }\end{array}$ & $\begin{array}{r}11.0 \\
11.8 \\
+11.8 \\
\end{array}$ & $\begin{array}{r}9.0 \\
8.5 \\
+4.0 \\
\end{array}$ & $\begin{array}{r}<1.0 \\
10.8 \\
+10.8 \\
\end{array}$ & $\begin{array}{r}<1.0 \\
10.3 \\
+10.3 \\
\end{array}$ & $\begin{array}{r}<1.0 \\
12.5 \\
+12.5 \\
\end{array}$ & $\begin{array}{r}<1.0 \\
8.5 \\
+8.5 \\
\end{array}$ & $\begin{array}{r}<1.0 \\
10.7 \\
+10.7 \\
\end{array}$ & $\begin{array}{r}2.0 \\
14.6 \\
+13.6 \\
\end{array}$ & $\begin{array}{r}1.0 \\
6.5 \\
+6.0 \\
\end{array}$ & $\begin{array}{r}<1.0 \\
12.7 \\
+12.7 \\
\end{array}$ \\
\hline $\begin{array}{l}\text { DJ } 81004-O B(10) \\
\text { SAMPLE NO. } \\
\text { MOLE NO. } \\
\text { DEPTH. FT. } \\
\text { DH (1) } \\
\text { COND., mmHOS (2) } \\
\text { SATURATION, } \%\end{array}$ & $\begin{array}{c}69 \\
\text { OB21 } \\
185.0- \\
195.0 \\
7.8 \\
1.13 \\
43.7\end{array}$ & $\begin{array}{c}70 \\
0322 \\
195.0- \\
197.7 \\
7.5 \\
0.98 \\
49.6\end{array}$ & & & & & & & & \\
\hline $\begin{array}{l}\text { PARTICLE SIZE } \\
\text { \% SAND } \\
\text { * SILT } \\
\text { * ClaY }\end{array}$ & $\begin{array}{l}47 \\
33 \\
20\end{array}$ & $\begin{array}{l}31 \\
29 \\
40\end{array}$ & & & & & & & & \\
\hline $\begin{array}{l}\text { TEXTURE (3) } \\
\text { CALCIUM, madi (4) } \\
\text { MAGNESIUM, mod/1 (4) } \\
\text { SODIUM, mea/1 (4) }\end{array}$ & $\begin{array}{l}L \\
7.60 \\
3.53 \\
0.81\end{array}$ & $\begin{array}{l}\mathrm{C} \\
6.10 \\
2.42 \\
0.99\end{array}$ & & & & & & & & \\
\hline 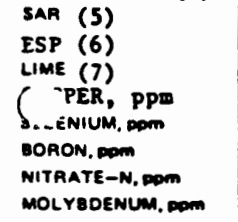 & $\begin{array}{l}0.34 \\
0.69 \\
1.0 \\
1.5 \\
0.08 \\
0.3 \\
<1.0 \\
0.13\end{array}$ & $\begin{array}{l}0.48 \\
0.60 \\
1.0 \\
4.3 \\
0.46 \\
0.3 \\
<1.0 \\
0.20\end{array}$ & & & & & & & & \\
\hline $\begin{array}{l}\text { POT. ACIDITY ( } 8) \\
\text { NEUT. POT. ( } 9 \text { ) } \\
\text { ACID BASE POT. }\end{array}$ & $\begin{array}{r}<1.0 \\
10.0 \\
+10.0 \\
\end{array}$ & $\begin{array}{r}1.5 \\
10.3 \\
+9.5 \\
\end{array}$ & & & & & & & & \\
\hline
\end{tabular}


EHFREY ENERGY LABORATORIES, INC.

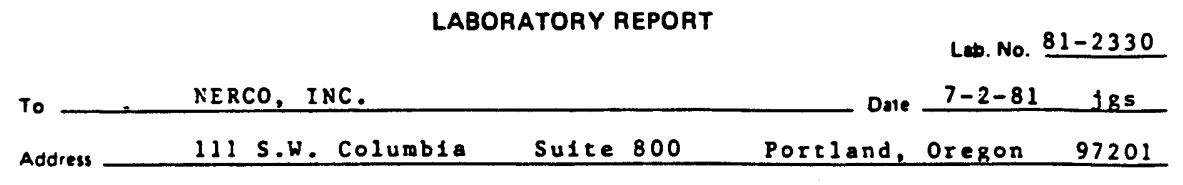

WYOMING SOIL OVERBURDEN / INTERBURDEN ANALYSIS

MINE Dave Johnston

(Analysis by procedures recommended by Land Ouality Division Guidelines, Wyoming Department of Environmental Quslity.)

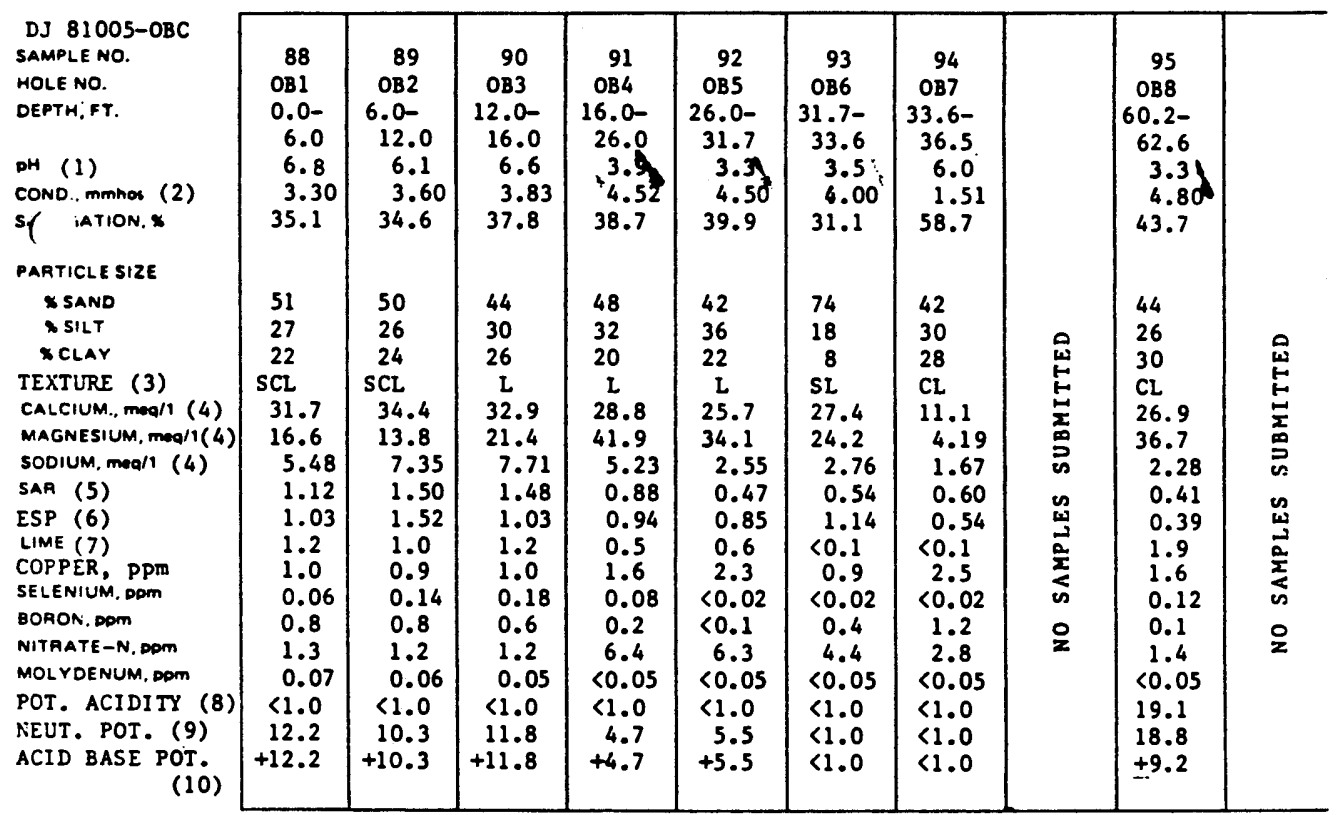

NOTES: (1) MEASURED ON SATURATED PASTE. (2) CONDUCTIVITY, mohos/cm $25^{\circ} \mathrm{C}$, MEASLRED ON SATURATED EXTRACT. (3) USDA TEXTURAL CLASS. KEY: S=SAND(Y); SI=SILT(Y); L-LOAM(Y); C=CLAY. (4) MEASURED ON SATURATED EXTRACT. (5) SODIUM ABSORPIION RATIO. (6) EXCHANGEABLE SODIUM PERCENTAGE. (7) \% AS $\mathrm{CaCO}_{3}$ (8) MEQ. $\mathrm{H}^{+}$PER $100 \mathrm{~g}$. (9) TONS $\mathrm{CaCO}_{3} / 1000$ TONS DRY MATERIAL. (10) TONS $\mathrm{CaCO}_{3} / 1000$ TONS DRY MATERIAL + - LIME EXCESS: - - LIME DEFICIENCY. 


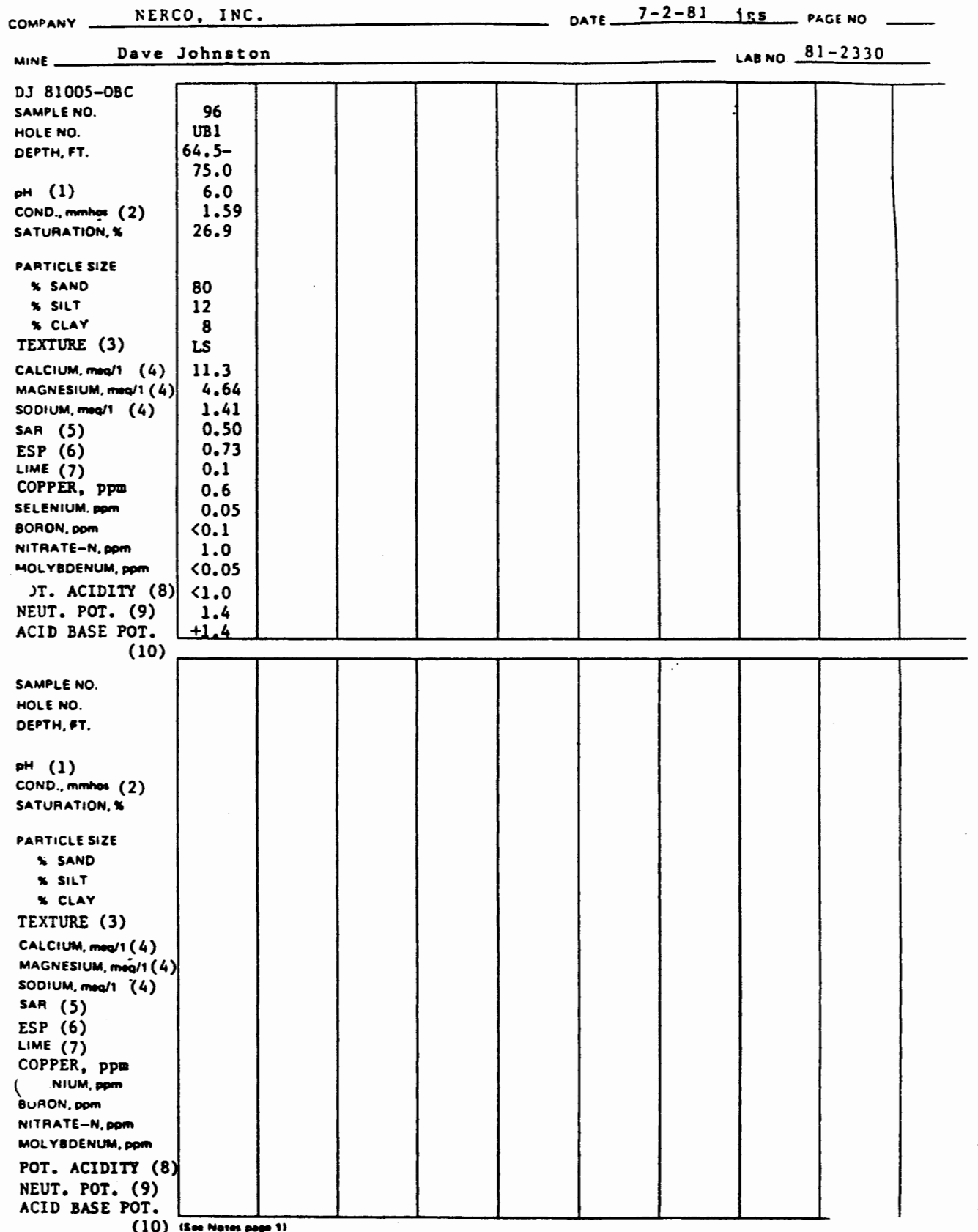


ENERGY LABORATORIES, INC.

EERC

Lab. No. $81-2330$

To - NERCO, InC. Date $7-13-81$ igs

Address 111 S.W. Columbia Sulte 800 Portland. Oregen 97201

WYOMING SOIL OVERBURDEN / INTERBURDEN ANALYSIS

MINE

(Analysis by procedures recommended by Land Quality Division Guidelines, Wyoming Department of Environmental Quality.)

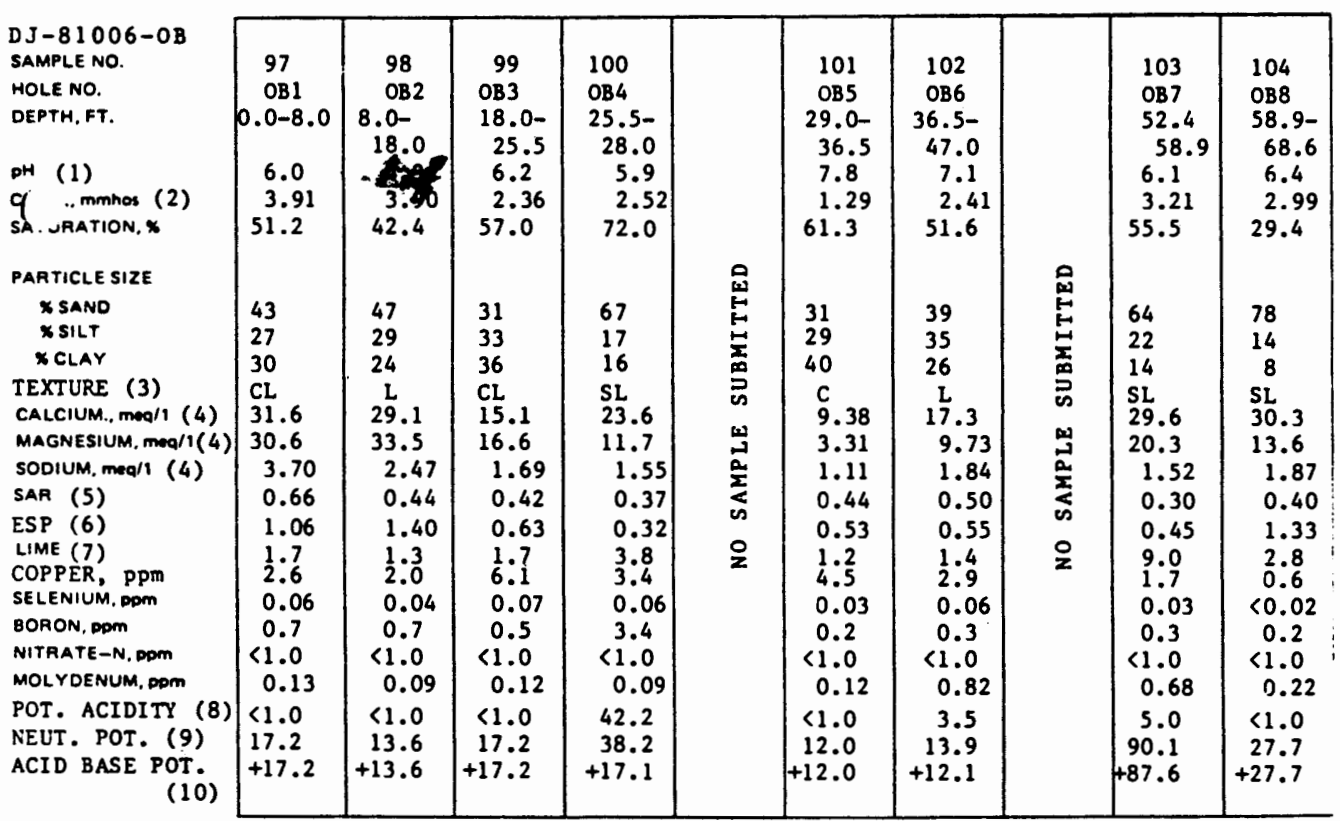

NOTES: (1) MEASURED ON SATURATED PASTE. (2) CONDUCTIVITY, monhos/cm $25^{\circ} \mathrm{C}$, MEASURED ON SATURATED EXTRACT. (3) USDA TEXTURAL CLASS. KEY: S=SAND(Y); Si=SILT(Y); $L=L O A M(Y)$; C=CLAY. (4) MEASURED ON SATURATED EXTRACT. (5) SODIUM ABSORPTION RATIO. (6) EXCHANGEABle SODIUM PERCENTAGE. (7) \% AS $\mathrm{CaCO}_{3}$ (8) MEQ. H PER $100 \mathrm{~g}$. (9) TONS $\mathrm{CaCO}_{3} / 1000$ TONS DRY MATERIAL. (10) TONS $\mathrm{CaCO}_{3} / 1000$ TONS DRY MATERIAL + - LIME EXCESS: - = LIME DEFICIENCY. 


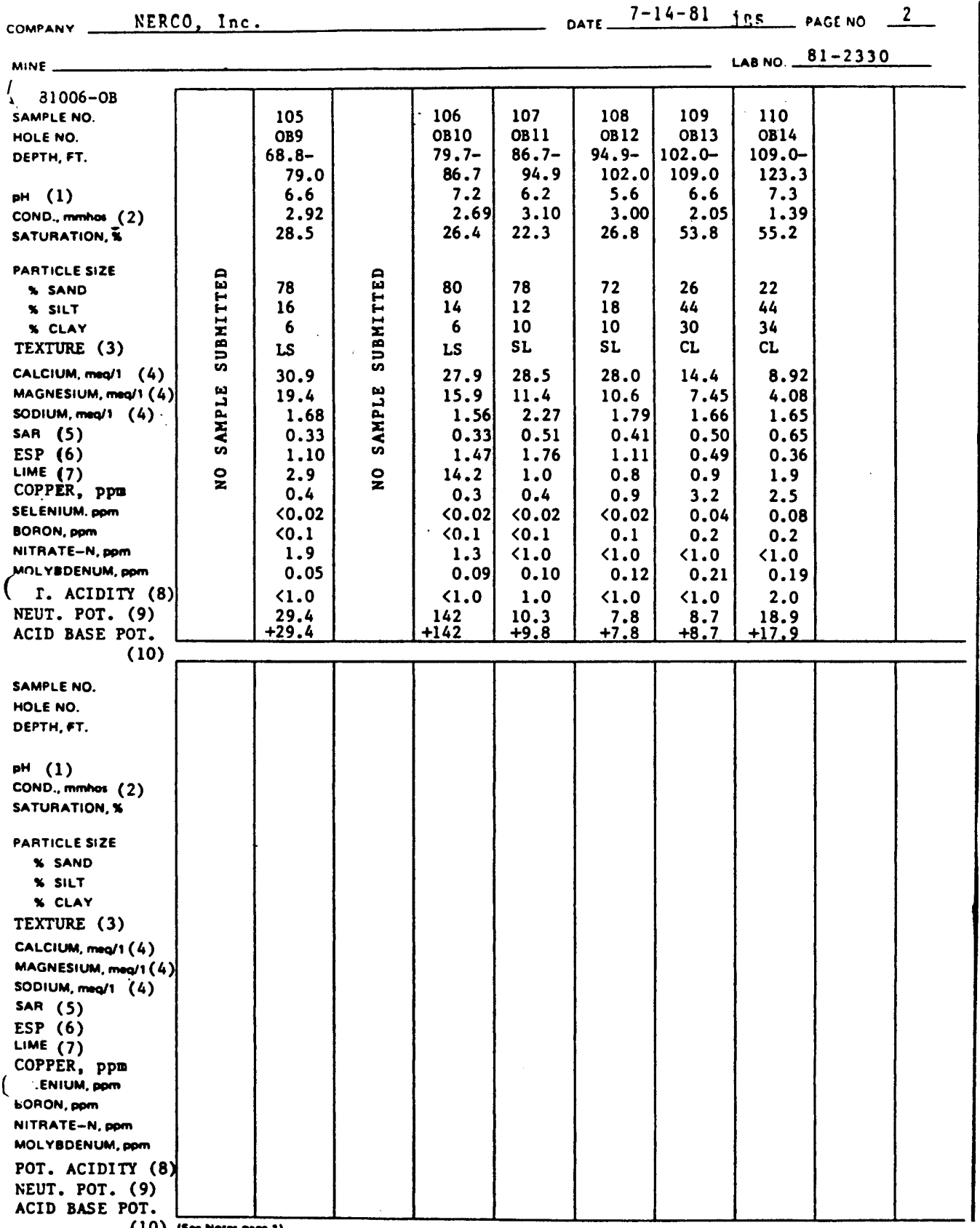

(10) isow Notes now I) 